Historic, Archive Document

Do not assume content reflects current scientific knowledge, policies, or practices. 

MDDKN

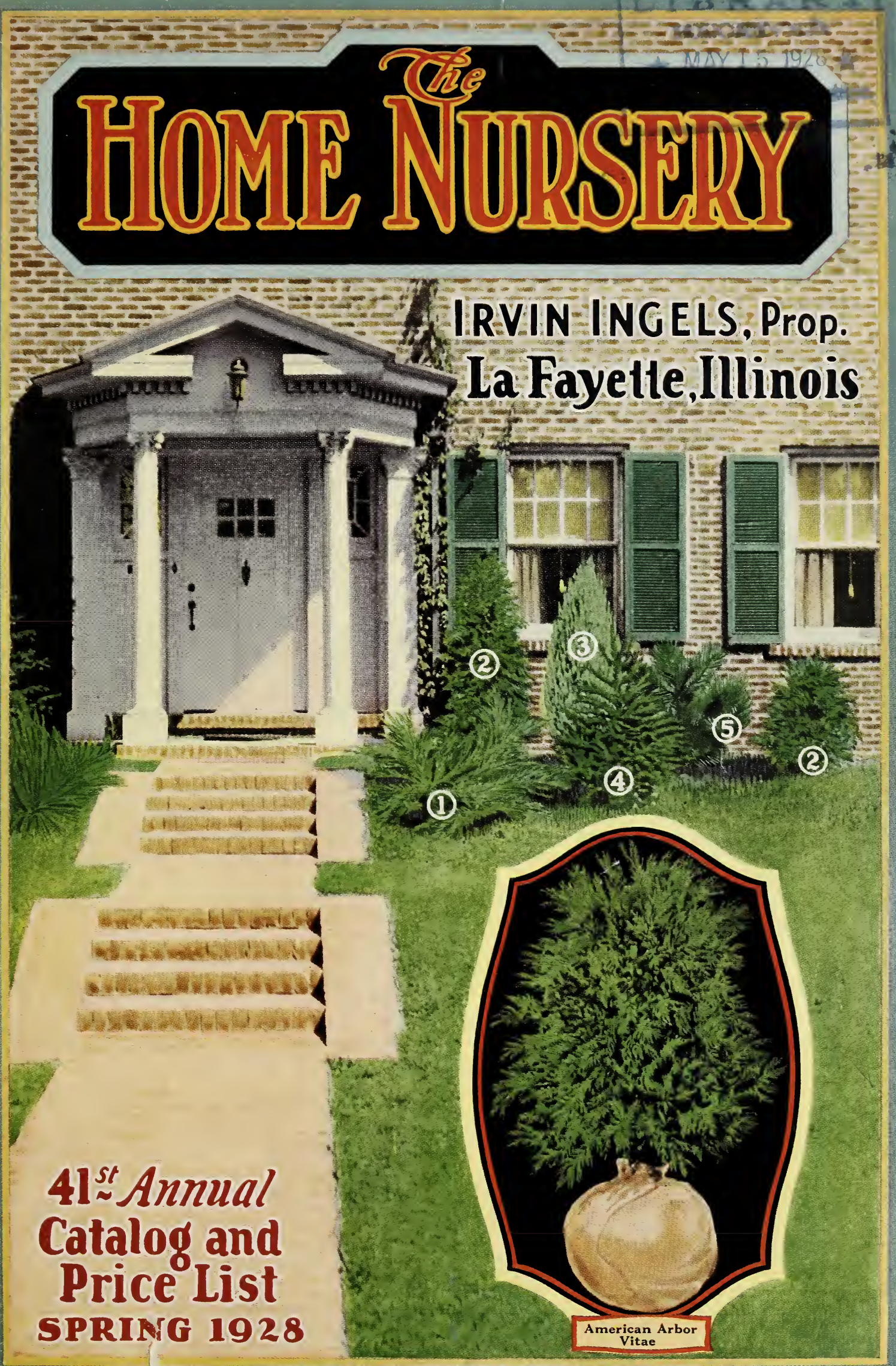




\section{Our Front Cover Page}

The picture of the entrance of a dwelling, shown by the artist, on the front cover of this catalog is taken from an actual planting of 6 Evergreens furnished by the Home Nursery and on which we are making a special low offer. The names are as follows:

No. 1. Juniperus Pfitzeriana

No. 2. American Arbor Vitae

No. 3. Irish Juniper

No. 4. Norway Spruce

No. 5. Austrian Pine

They run in height from 2 to 5 feet according to variety. A full description of the above Evergreens will be found in the body of the catalog under Evergreens.

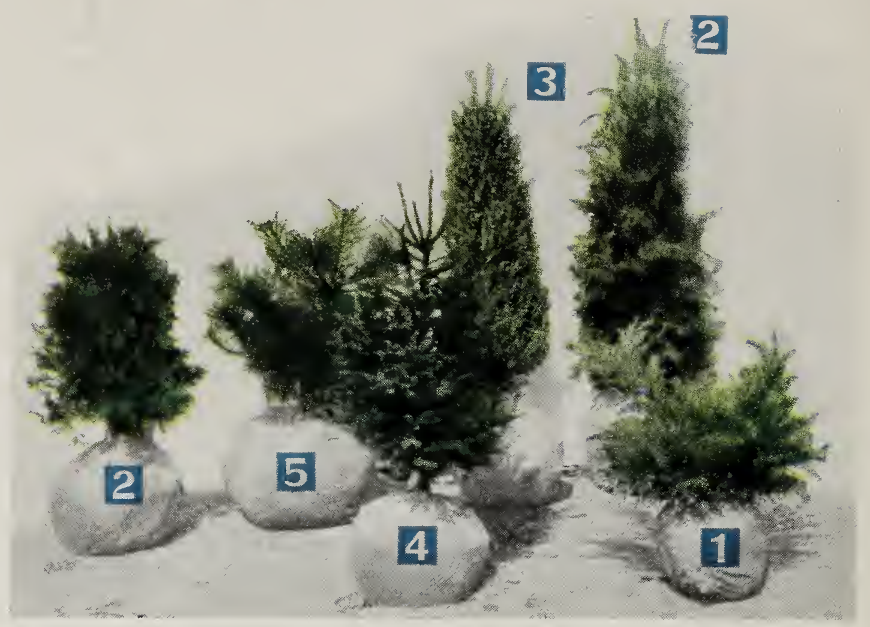

\section{Our Special Offer}

The above 6 Evergreens, as shown in the cut, will be packed, F. O. B. this station for $\$ 12.50$. Or a double order for $\$ 24.00$. This would give you 6 trees for each side of your doorway. We are making this special offer in order to introduce our Evergreens and show you our manner of digging and packing, as well as the quality of stock we grow.

The arrangement and varieties shown will fit any opening or front entrance and give a very immediate and pleasing landscape effect.

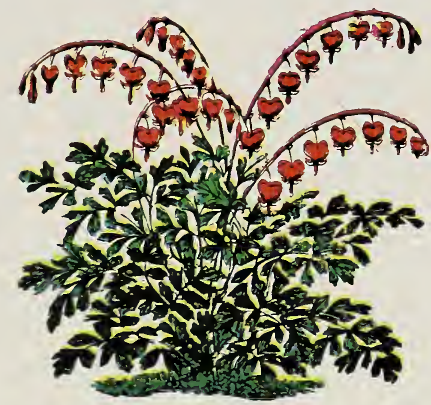

\section{Plant Bleeding Heart Among Your Evergreens}

It is an old-fashioned favorite. Its arching stems bear drooping heartshaped flowers of white and rose-red. It is perfectly at home in any part of the hardy border and especially valuable for planting in shade. Set among Evergreens it gives a splendid contrast and is very effective. Very rare. Each 50c.

Scene in Home Nursery Grounds. Preparing largesized Evergreens for shipment. Ball of earth insures success in planting.
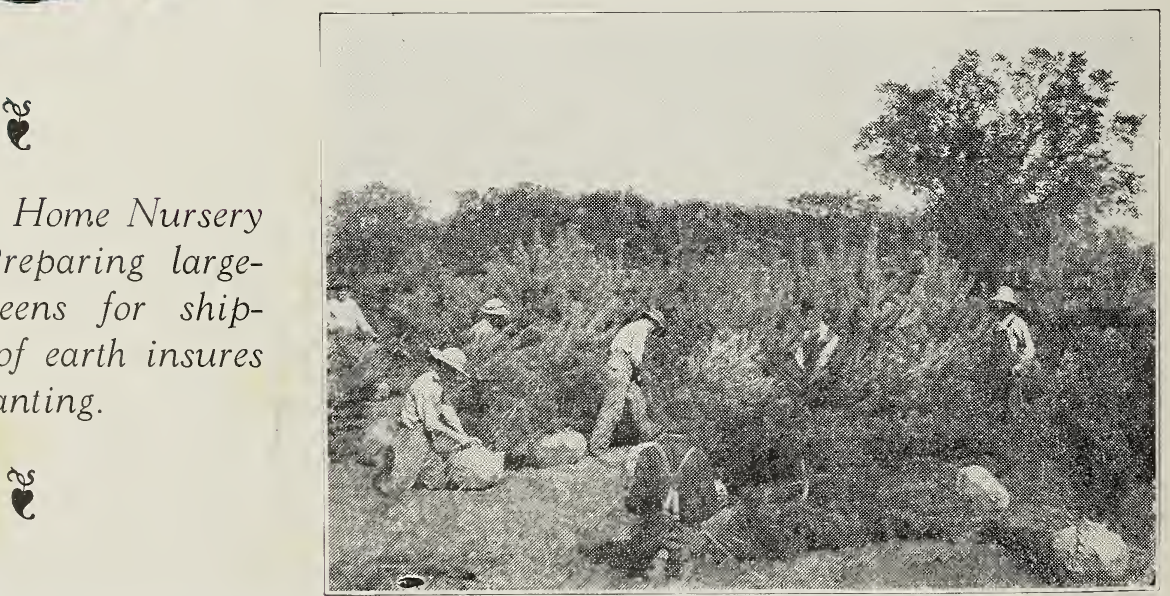


\section{Views}

American Arbor Vitae, 2 to 3 feet high. View taken in our grounds this fall. Fine as can be grown.
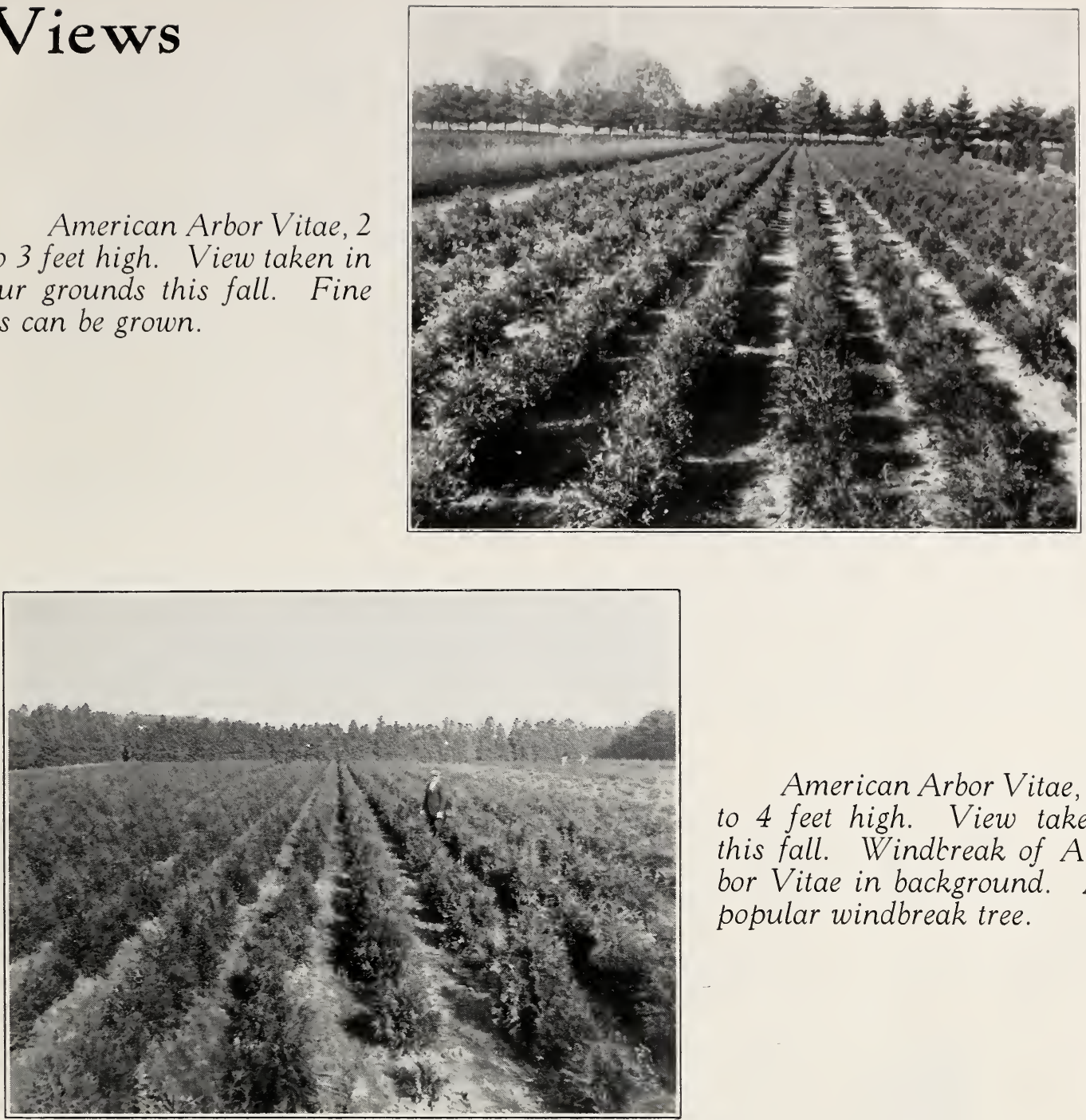

American Arbor Vitae, 3 to 4 feet high. View taken this fall. Windrreak of $A r-$ bor Vitae in background. A popular windbreak tree.

American Arbor Vitae, 4 to 6 feet high. View taken in our grounds this fall. These are all specimen trees.

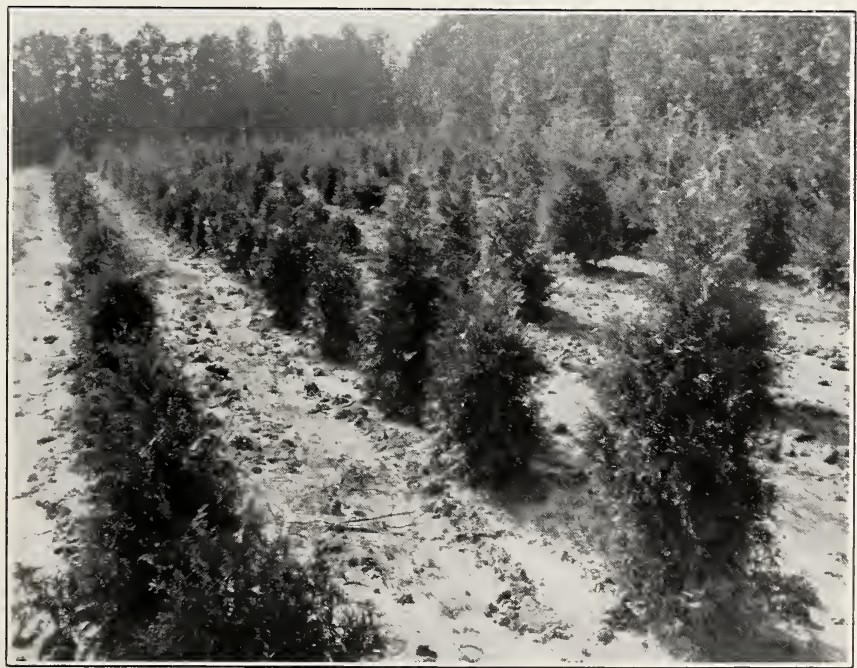




\section{Introductory}

Our Forty-first Annual Catalog and Price List is herewith presented, and it is, we trust, with pardonable pride, are able to point back over a period of over forty years growing trees, shrubs and plants for the market. During these years of work and planning, with its ups and downs, ins and outs, our constant aim has been to furnish everything to our customers of the very best quality, true to label and at a reasonable price.

The large patronage we enjoy is proof that our customers have been satisfied. In fact our 41 years of successful business is your guarantee.

To those who have never dealt with the Home Nursery, we invite you to visit our grounds when possible and acquaint yourselves with the high quality of stock grown and our method of digging, handling and packing for shipment.

The real value and quality of a tree or plant depend upon its fruitfulness and vigor. Anything in the plant line, as well as animal, can be dwarfed or stunted in growth the first few months or years of its life, from which it never recovers. Knowing this, we give everything the highest culture and use an abundance of fertilizers. In order to have an abundance of fertilizers on hand at all times we feed from one to three carloads of steers each year.

There is perhaps no dealing in which the element of faith enters so largely as the matter of buying nursery products. There is no possible way of telling the value of a tree, shrub or plant until it has come to maturity, and in many cases years after planting, when it is too late to correct matters.

\section{Landscape Service}

The Home Nursery Landscape Service has grown to be a very important branch of the business and we are able to point with pride to a large number of private estates, parks, cemeteries, factory grounds, etc., which we have designed and executed the past few years.

With our large list of ornamentals, such as evergreens, shrubs, trees and plants, we are able to execute
There is nothing so discouraging or annoying as to have planted a fruit tree, for instance, and after waiting years for it to come into fruiting, find it to be entirely worthless, and nothing like you had expected, or was promised.

Our respective customers will appreciate buying from a firm of long standing and good reputation, knowing that whatever they buy will be of the best quality and absolutely true to label.

With out long years of study and experience we are in position to give expert advice in Orcharding and Fruit Gardening as well as Landscape plans and designs, and you are invited to submit to us your problems along these lines. This advice is free to our customers at all times.

In making up this Catalog we have gone to no little trouble and pains to give full and accurate descriptions as well as cultural directions of each particular subject. This information comes to us through long years of study and experience. The illustrations are taken from actual photographs and the colors are true to nature. We trust you will find the Catalog a source of information as well as an aid to making up your orders.

This Catalog is our only salesman and am sure our respective customers will find more satisfaction in ordering from it than from a windy salesman to whom they pay double the price.

any planting either large or small in a most satisfactory manner.

It is just as important in planting the home grounds to have a definite plan, furnished by a competent landscape architect, as to have a plan for building a modern dwelling. Attractive landscape effects are not made by guesswork but are the result of careful study and thinking.

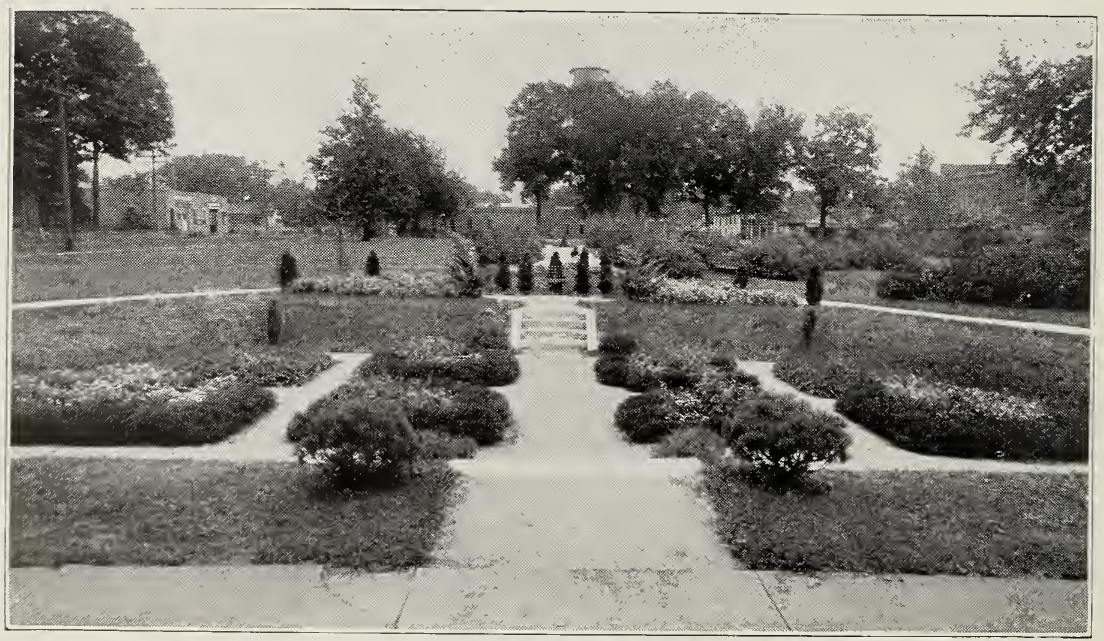

Sunken Garden in the City Park, Toulon, Ill., designed and executed by the Home Nursery landscape service, showing what can be done with an old public eyesore and dumping grounds. Civic pride is shown by the embellishment of vacant lots and unsightly places, adding the natural beauty to the town or city. 


\section{Landscape Service-Continued}

Before making extensive plantings you should have this department make a survey of your grounds and furnish you with a properly worked-out design for beautifying them. We make surveys and submit sketches in blue-print together with an estimated cost of planting. We do everything from start to finish and save you both money and time.

The Home Nursery Greenhouses are an important branch of the business and the large and increasing trade in this department indicates the quality of stock sent out. A large and popular list of Cut Flowers always on hand at reasonable prices. In buying of us you get fresh cut stock that you will find keeps more than a week longer than stuff bought from a dealer.

\section{Important to Purchasers}

ORDER EARLY. To those familiar with the rush at the packing season, it is obvious that orders should be received early. Please place your order as far in advance of the shipping season as you possibly can, stating when you would like stock sent.
All the Popular Annuals for bedding and ornamental planting. Plants for Vases, Hanging Baskets, Porch Boxes, etc. Vegetable Plants in large quantities. See page 12 in the Catalog.

We arrange and plant formal beds with various flowering and ornamental plants that give beauty and fragrance throughout the season. Confer with this department and see how cheaply you can have this work done.

To those who have never bought of us, we will say that we employ no agents or salesmen, but deal direct. And you are assured of paying but one profit; a comparison of our prices with those you have formerly paid will show that they are less than half you pay traveling tree agents.

REPLACING. We do not replace stock that dies the first season at any reduction. Some firms offer to replace free, but if you will compare our prices with theirs, you will see that they can afford to do so.

\section{Location Map Showing Cement Roads Leading Directly to The Home Nursery}

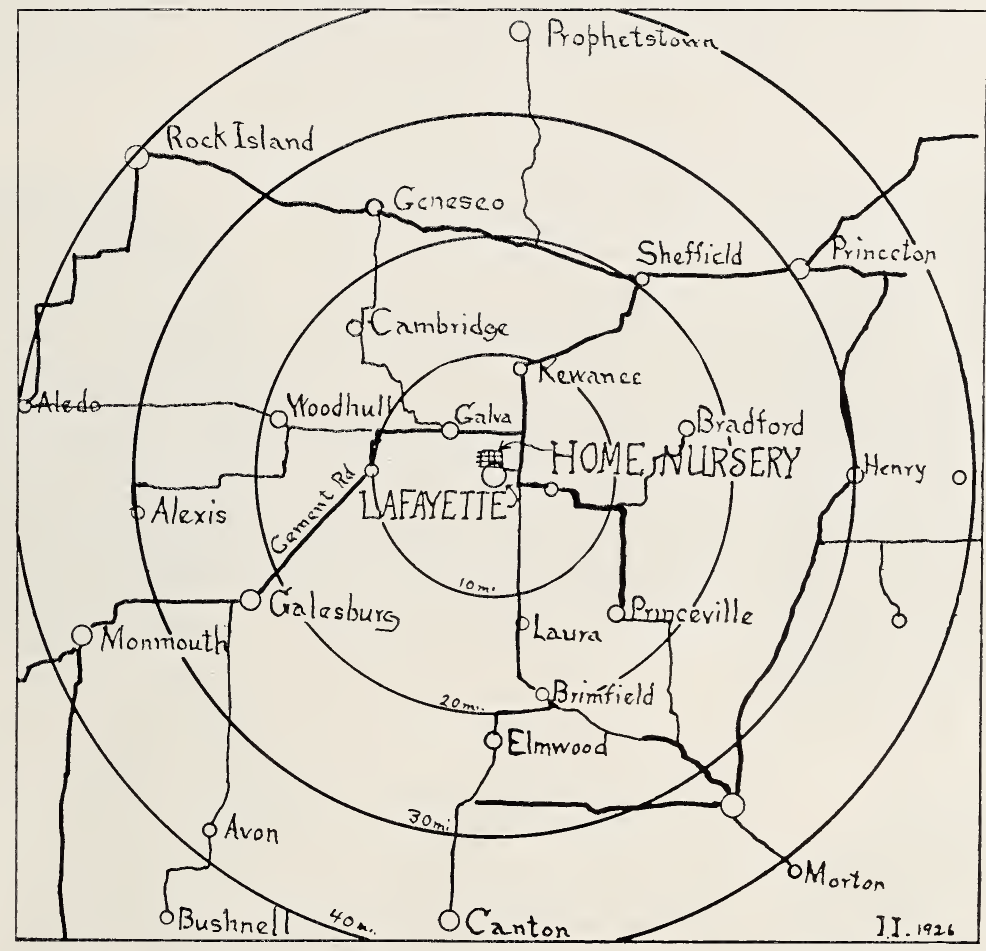

The Home Nursery is located adjoining the village of La Fayette in the most fertile region of the corn-belt of Illinois. On the Peoria branch of the C.. R. I. \& P. R. R., midway between Peoria and Rock Island. Also near the mail line of the C., B. \& Q. R. R., and only fifteen miles from the main line of the Santa $\mathrm{Fe}$. Thus we are able to ship over three of the largest railroad systems in the country without going through heavily congested junction points where freight is held up indefinitely.

Easily accessible by Auto from every direction over cement highways; being but two miles off Route 30 and connected by improved gravel road.

This very favorable location enables one to reach the Nursery via Auto from most any section of the State. Only an hour's drive from Galesburg or Elm- wood; an hour and a half from Peoria and less than two hours from Rock Island. An easy drive from Bushnell or Macomb. Cement all the way.

Coming to the Nursery via Auto enables one to make selection of such stock as is needed and taking his purchase with him the same day, saving both time and expense as well as assuring success in planting.

Driving fifty or one hundred miles to the Nursery over cement roads is a pleasure trip and the most satisfactory way to make your purchase, as you can see just what you are getting.

Visitors to the Nursery are welcome at all times, but please do not ask us to dig or pack stuff on Sundays. Call or address,

IRVIN INGELS, Proprietor, LA FAYETTE, ILL. 


\section{Apples}

The most important fruit we have for this latitude, and the only fruit we can have in fresh condition the year round, of our own growing. There are so many kinds that ripen at different seasons of the year, some in early summer while others that are at their best late in the spring. So with a reasonably damp, cool cellar one can have apples in good condition up until the time the new crop is ready the first of July.

The rosy cheek of the apple will give one the rosy cheek of youth. The old saying that should be classed with the Proverbs, "An apple a day will keep the doctor away," contains more trith than poetry.

There is a sentiment about the Farm Orchard that grips one more than any other feature of the homestead. There is nothing that brings such pleasant memories as the old orchard with its golden pippins and rosy-cheeked Maiden-Blush, or in the springtime when the trees are ladened with blossoms and fragrance. What a tragedy to a family of boys and girls raised on a farm without an orchard.

There is not a dweller on a farm that need be without this heaith-giving fruit the year round. Some people try to argue that they can buy their supply of apples cheaper than they can grow them. It may be possible, but they never do it, but go without. The orchard pays as a protection to the place as well as for the ornament and landscape effect it gives. It is even worth the cost for the blossoms and shade it affords. But when it comes to having honest-to-goodness apples right from the trees, there is nothing like it.

Still many people omit this most important feature of their homestead. Don't kid yourself that apples do not grow here and that planting an orchard would be a waste of time and money. Illinois is one of the leading apple-growing states in the Union. And while a good many kinds are improved in appearance as grown in the irrigated valleys of the West, there is none that have the flavor and keeping qualities that will compare with apples grown in this latitude, in the prairie state.

The proper selection of kinds is a very important factor in providing fruit the season through. But few of the summer kinds will be needed, as compared with the late fall and winter varieties.

The trees we have to offer are grown on our own grounds. with soil and climatic conditions same as yours and will succeed. Are not to be compared with stock grown in some other state. The varieties offered are selected from a list that has been tried reach full maturity in ten to fifteen years.

out in this particular region of the corn-belt and you will make no mistake in planting any or all of them.

Apples come into bearing usually after three or four years and

Price of Apple Trees-4 to $6 \mathrm{ft} .$, each $75 \mathrm{c}$; per $10 \$ 7.00$; per $100 \$ 65.00$.

\section{Summer Varieties}

EARLY HARVEST (Yellow Harvest)-Medium to large size; pale yellow. Flesh very white, tender and juicy, crisp, with a rich sprightly subacid flavor. Altho a very old variety, on account of its beauty, its excellent qualities for desert and cooking and its productiveness, it is yet one of the very best extra early kinds. It begins to ripen about the first of July and continues throughout the month.

OLDENBURG (Duchess of O1denburg) - One of the most hardy and profitable kinds in cultivation. Tree among the hardiest and one of the few that will stand the climate of northern Iowa, Minnesota, Montana and other cold locations. Medium sized, red striped and a favorite on account of its rich acidity and splendid cooking qualities. Season the last of July to September. Regular and abundant bearer.

RED JUNE (Carolina Red June)-Tree very vigorous and upright growth and early and abundant bearer. Medium or below in size, shaded deep red. Flesh very white, tender, juicy, with a brisk subacid flavor. Begins to ripen the last of June. A very old and favorite kind.

YELLOW TRANSPARENT - This variety as introduced from Russia in 1870 by the U. S. Department of Agriculture and is one of the very hardiest and earliest bearers grown, usually bears the second year after planting and sometimes bears in the nursery row. Of vigorous upright growth, but never makes a large tree. Fruit medium, skin clear white at first, becoming pale yellow when fully matured. Fruit may be used from 10 days to two weeks earlier than any other kind. Extremely productive.

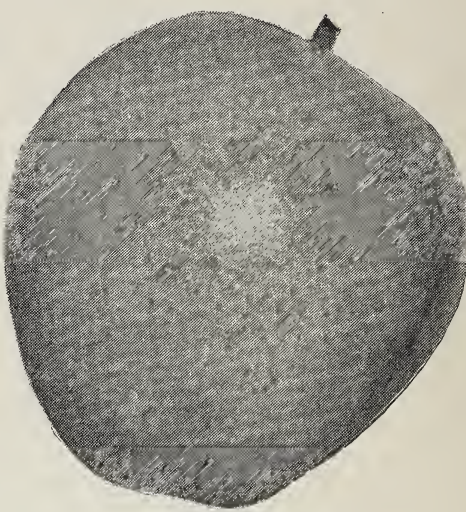

Yellow Transparent

\section{Fall Varieties}

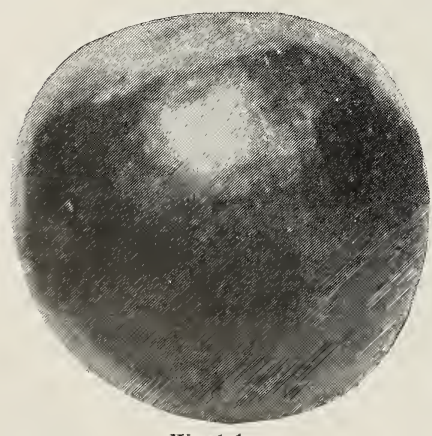

Wealthy

AUTUMN STRAWBERRY - Medium upright spreading tree, an abundant bearer, one of the old reliable kinds. Fruit light red, striped. Flesh yellowish white, very tender, juicy, pleasant vineous, subacid. Ripens September and October.

MAIDEN BLUSH-Well known variety that needs no description. A good hardy tree and splendid bearer. Fruit of uniformiy large size, smooth, with a delicate waxen appearance, pale yellow in the shade and with a brilliant crimson cheek next the sun. Flesh white, sprightly, tender, pleasant subacid. Has no equal for cooking or drying. Season September.

POUND SWEET - Thrifty growing tree, of vigorous upright growth and a great bearer. Fruit very large, often weighing more than a pound. Color yellowish-green; flesh rather coarse, but excellent sweet flavor, rich and juicy. Season October to December.

SNOW (Famuse)-Gets its name from the snow-white color of its flesh. It is an excellent, productive autumn apple and is especially valuable in northern latitudes. Fruit of medium size, roundish, mostly red in the sun. Flesh remarkably white, very tender, juicy and with a slight perfume. For eating out of hand it is in a class by itself. Season October to December.

WEALTHY - Vigorous spreading tree, extremely productive. This beautiful moderate sized, brilliant red apple is of fine quality, one of the best of its season. It is a relatively good keeper and owing to the hardiness of the tree, its adaptability to cold climates and early bearing habit makes it a very profitable kind. Flesh white and tender, reddish stained and of excellent flavor. Season October to December.

To us, one pleased customer is worth a whole yard full of dissatisfied ones. 


\section{Winter Varieties}

BEN DAVIS-Is hardy and attractive, succeeds wherever apples are grown. There is no apple that has more favors on account of its hardiness, productiveness, beauty and endurance in shipping. It is excellent for cooking. There are better apples, but where Ben Davis succeeds, one can always be sure of success, owing to its regular and heavy bearing qualities. The fruit afterbeing handled and shipped in the ordinary way. November to April.

DOMONIE - Tree rather open spreading top, very hardy and vigorous; a heavy bearer, the branches being literally weighed down by the rope-like clusters of fruit. Fruit medium large size, flat, greenish-yellow in the shade, with striped and splashes of red in the sun, and large russet specks in the shade. Flesh white and extremely tender and juicy, with a sprightly pleasant flavor. Season December to March.

DELICIOUS - Tree very hardy, strong upright grower and comes into bearing soon. Fruit large, near!y covered with brilliant dark red. Flesh fine-grained, crisp and melting, juicy, with a delightful aroma; of very highest quality. This no doubt is the most popular and highest priced eating apply on the market. Season December to March. Price each $\$ \mathbf{1 . 0 0}$

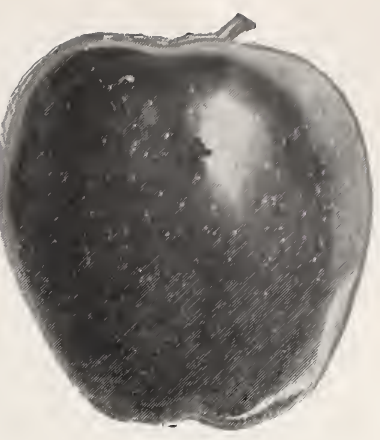

Delicious

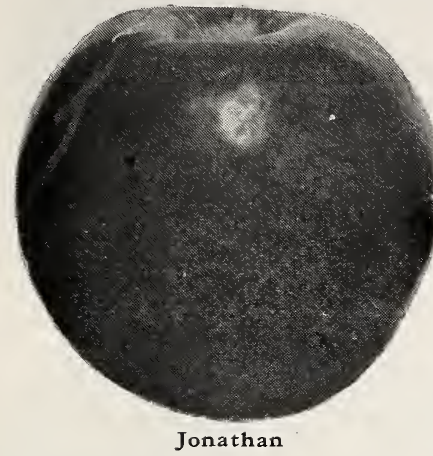

Jonathan

GRIMES GOLDEN PIPPIN-Tree is vigorous grower and a hardy late bloomer. Comes into bearing young. Fruit medium to large, cylindrical in shape; flesh tender, juicy and rich, an old time favorite never loosing its popularity. A favorite in all markets and invariably brings the highest price. Color a transparent golden yellow. Season December to April.

JONATHAN-For years the standard of quality by which other sorts have been gauged Trees are long lived, productive and an early bearer. A brilliant red apple, high!y flavored and of excellent quality, being tender, juicy, spicy and rich-a splendid family sort and highly profitable for market. Season December to April.

MAMMOTH BLACK TWIG-Rapid grower, makes a very large tree and a good bearer. Fruit resembles the Winesap and is very solid, keeps very late, does not mellow up until spring. Subacid and of high flavor. Season March to April.

ROMAN STEM-Tree very productive, moderately vigorous, spreading irregular. Fruit scarcely medium size, roundish, whitish yellow; flesh tender, juicy, with a rich, pleasant, musky flavor. A very old variety, but not as widely planted as it should be on account of its excellent flavor. Season December to March.

ROME BEAUTY - Large, roundish, mostly covered with bright red on pale yellow ground Flesh tender, juicy and fine flavored. Ripens in early winter. The large size and beautiful appearance makes it a very popular kind. Flavor and quality way above the average. Season November to March.

ROXBURY RUSSET-Merium to large russet apple of fine flavor and of good keeping qualities. An old favorite. Season mid-winter.

STAYMAN'S WINESAP - Tree vigorous, hardy, spreading. An early and very productive fruit, medium size, roundish, approaching conic; skin smooth, greenish yellow, splashed and striped with red and purple; flesh yellow, firm, tender, juicy, rich, subacid, aromatic; quality best. Splendid late keeper. Season December to April.

SEEK-NO-FARTHER-An old favorite variety that succeeds throughout the west. Tree very moderate grower but a splendid bearer. Fruit medium or large, roundish, slightly conical, striped with dull red, more or less russeted. Flesh tender, spicy of rich permain flavor. Season early to mid-winter.

NORTHERN SPY-Large, striped, mild, subacid, very tender and juicy and rich flavor. Its fine reputation brings high prices in the market and is always in demand. A fruit of the highest quality. Season early to mid-winter.

TOLMAN SWEETING-The very best of the winter sweet apples. Flesh white, firm and sweet. Excellent for winter baking. Keeps until spring. Trees are very hardy and productive. Season December to April.

WINESAP-Well known variety and one of the leading export apples. Fruit medium large, skin thick and very tough, almost entirely covered with dark red; flesh yellow, finegrained, firm, rich, crips, sprightly subacid quality excellent. Season December to April.

WILLOW TWIG-Spreading, somewhat drooping habit, very hardy and productive. Fruit medium to large size, light yellow, shaded and marbled with dull red. Flesh yellowish green, rather firm, pleasant subacid. One of the best keeping sorts. Is not at its best until March or Apri!.

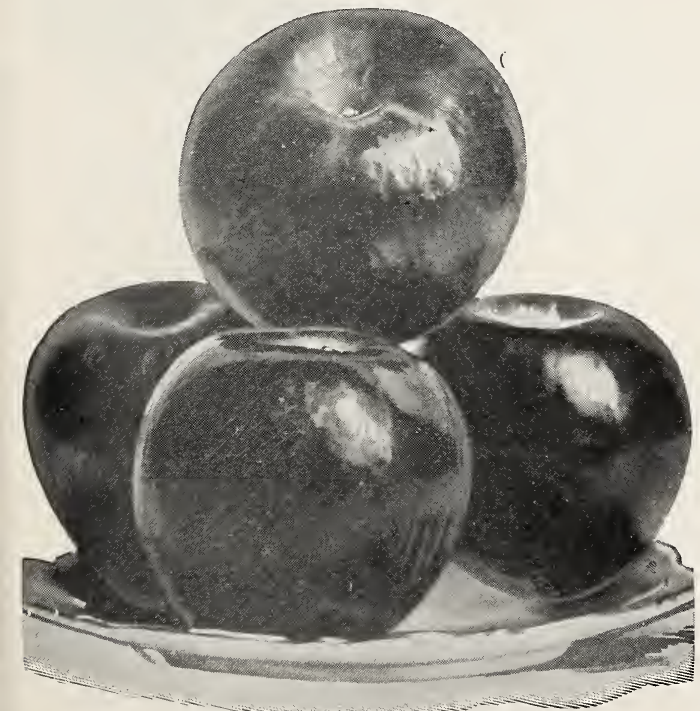

Winesap

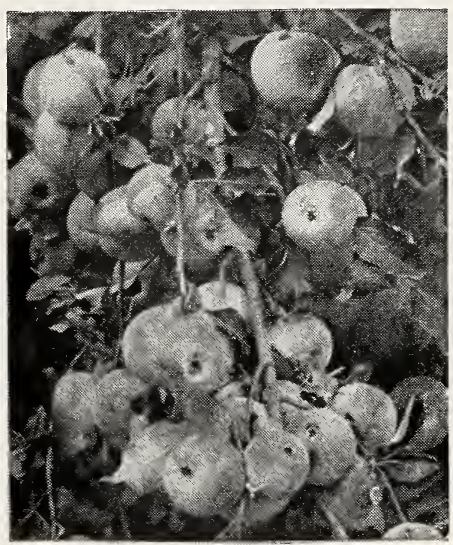

Stayman's Winesap

\section{Crab Apples}

Price, first class, each $\$ 1.00$

The varieties we have to offer are the very best kinds. The Transcendent is medium early while the Hyslop is late.

HYSLOP-Large, dark red, productive and valuable; best for all purposes; on account of its beautiful color it commands the highest market price.

TRANSCENDENT - This is one of the best and largest of the Siberian Crabs; the fruit is a bright yellow, striped with red; excellent for culinary purposes; immensely productive.

WHITNEY - One of the largest, glossy green, splashed carmine, firm, juicy, pleasant, great bearer; excellent for cider. August.

Your Dollar has twice the purchasing power when you buy direct from us, the grower. The Middle-Man's commission stays in your pocket. 


\section{Peaches}

Peaches are the earliest to come into bearing after planting of any of the tree fruits. Trees have been known to bear fruit within eighteen months from the time the seed sprouted and it is not uncommon for them to bear in three years from the seed. Trees planted out usually come into bearing the second year and come into full bearing in from three to four years.

It is the belief among a good many growers that a seedling tree is hardier or less liable to winter injury than one propagated by budding or grafting. They are greatly mistaken in this, as the mode in which a tree is propagated has nothing to do with its hardiness and as the peach, like other fruit trees, does not come true from seed, while a known hardy peach may be propagated and still retain its strength and not come

In propagating the Peach, like other fruit trees, the bud is transplanted from one tree to another and the nature of the bud is not changed in the least nor its hardiness affected.

Therefore, it is best to plant known varieties of peaches, rather than trust to seedlings that may be tender as well as worthless in fruit no matter how hardy or fine the fruit was that the seed came from.

The Peach never makes a very large tree in this latitude and requires very little room, and may be planted as close as from 7 to 8 feet apart. It is a good tree to plant in a young orchard for fillers or nurse trees to be taken out in a few years.

The following varieties are all good and hardy kinds and well adapted to growing in this latitude. All are Freestones except as noted and of the finest quality. The list is arranged in their order of ripening. Price, First Class Trees, 50 cents each; $\$ 4.50$ per 10 .

RYDER'S EARLY - One of the few real early freestones; color yellow with red on the exposed side. Above medium size, flesh yellow and fine flavored. Tree hardy and extremely productive. Ripens first week in July.

CHAMPION-Trees of this variety are hardy and bear well. The fruit is large and desirable for shipping. It is very handsome, creamy-white, with a red cheek, sweet, rich and juicy. It ripens in August.

ELBERTA-The great market peach of the south and west. Perfectly hardy in the north and claimed by some to be the best all-around Peach. Fruit large and handsome, with lemon-yellow skin, red on the sunny side. Flesh a rich yellow with pink around the very free stone; tender and juicy.

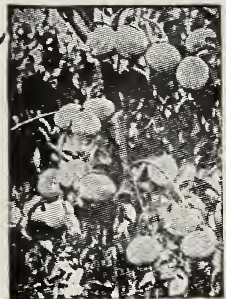

\section{Apricots}

The Apricot is one of the earliest of the tree fruits and is the first tree in the spring to show bloom. A rich, delicious fruit, coming between cherries and peaches. Very much like the peach in outward appearance, but like the plum in texture and quality. Aside from its value as a fresh fruit, the Apricot is fine for canning or drying and vast quantities are used in this way every year.

Our stock of trees are grown from bearing trees of known merit and are sure to give good results. They are absolutely hardy. Each $\$ \mathbf{1 . 0 0}$.

\section{Pears}

The list of Pears that succeed in this soil and climate is very limited as compared with the Apple. Most of the older standard kinds were a long time coming into bearing.

Now we have varieties that come into bearing soon after planting and are quite hardy and reliable. There are a few kinds that grow well on the Quince, which makes dwarfs of them, causing them to bear immediately and yearly.

The Dwarfs never make very large trees and can be planted much closer than standards. The dwarfing in no way affects the fruit but simply checks the growth of the tree, which causes bearing.

Our list of both Standard and Dwarts are the very best for this section of the corn-belt, and where planted in variety will give fruit from July to December. It is very important in handling pears to gather the fruit from a week to ten days before fully ripe and finish the ripening in a dark cellar, which greatly improves the flavor.

\section{Standard Trees}

3 years old, 5 to $z \mathrm{ft}$., each $\$ 1.00$.

BARTLETT-The leading commercial variety; one of the most popular for dessert and canning. Large clear yellow, with blush on sunny side. Flesh is white, fine-grained, juicy and sweet. Tree is vigorous, very productive, hardy, bears young.

KIEFFER - A large, handsome pear and an excellent keeper. The trees are very hardy and begin to bea when quite young. The fruit is a rich yellow with a reddish cheek. If picked about October 1 st, when it takes on a slight yellow tint, and put in boxes in a dark place to ripen, they are fine eating out of hand and superior to most pears for canning. Its excellent flavor and handsome appearance make it a desirable market variety.

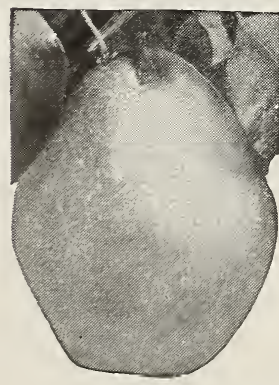

Duchess

\section{Dwarf Pear Trees}

Three-Year-O1d First C1ass $\$ 1.00$ each.

Dwarf Pears are valuable, as they come into bearing immediately and are well adapted to small gardens. It is propagated on Quince roots, which make the tree a slow dwarfish grower, and less subject to blight than the standard. The dwarfing does not affect the fruit in any way. In orchard planting they may be set much closer than the standard trees. DUCHESS - Very large, greenish-yellow, some times russeted. The flesh is white, juicy, buttery, melting and sweet. Ripens from October to November.

SECKEL - One of the best and highest flavored Pears known. Rather mall, with a rich, yellowish-brown skin and white melting flesh. Season,

August and September. Tree very productive.

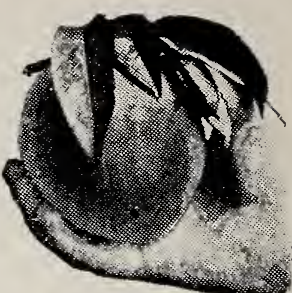

Ryder's Early

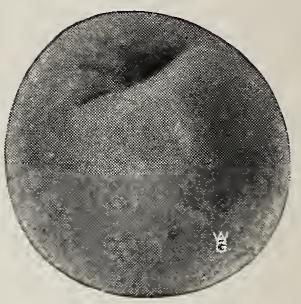

Champion

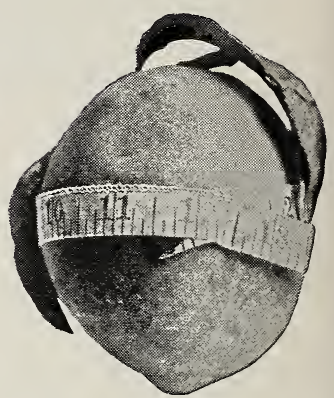

Elberta

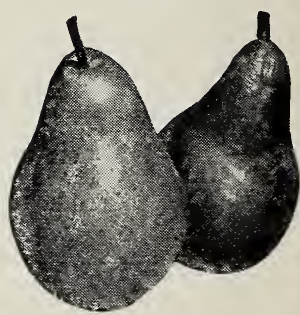

Bartlett

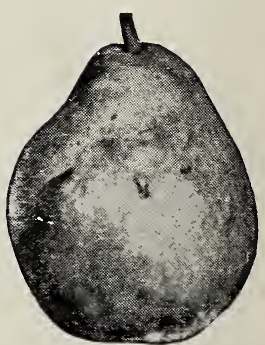

Kieffer

In this section of Illinois it is a very easy matter for a farmer to raise all the fruit his family can use, but not one out of fifty does it. 


\section{Cherries}

The Cherry begins to bear when only a few feet in height and is an annual bearer. The fruit is fine and delicious and one of the earliest of the tree fruits. And when it comes to cherry pie "Oh boy," it can't be beat.

No land owner need to be without this early and wholesome fruit. The trees are absolutely hardy and unusually free from insect pests. There is no fruit that will give as quick and as large returns as the Cherry.

The Oxheart or Sweet Cherry does not succeed in this section. We have frequent calls for this valuable kind and regret very much that they cannot be grown here.

Have tested a number of kinds and offer only the best. Our trees are budded upon the Mahaleb stock, which dwarfs them to some extent, so that the trees do not grow so tall or rapid and do not sprout from the root.

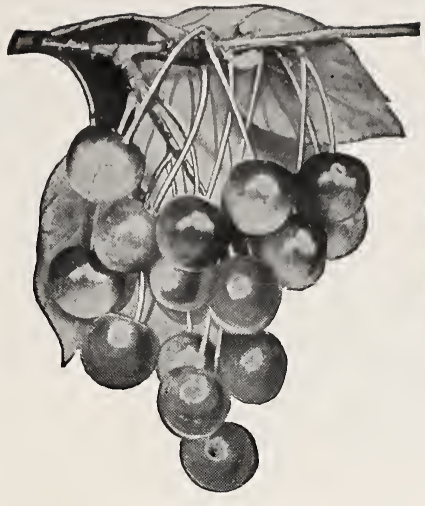

Farly Richmond

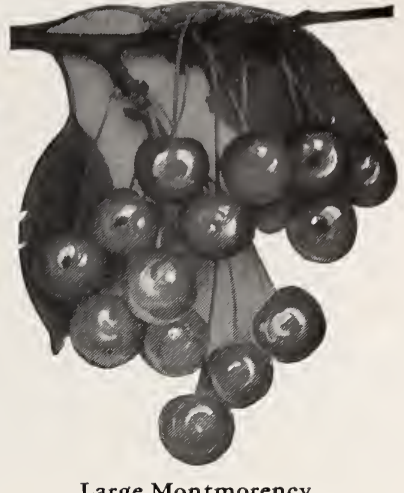

Large Montmorency

First Class Trees $\$ 1.00$ each.

EARLY RICHMOND-This is perhaps the most popular and valuable Cherry yet produced. It is very prolific and bears bright red, juicy fruit, rather acid in flavor and unexcelled for cooking. Tree very hardy. Ripens about 10 th of June.

\section{Plums}

The plum being a native fruit is of the most easy culture and an abundant bearer. There is an endless variety of colors and flavors as well as different times of ripening, extending from the middle of July to late fall.

The fruits are of the finest flavors and one has only to taste a few kinds until he will be "Plum" crazy.

This is a tree that you can plant as close together as you like, as they seem to do best when planted in thickets, and are usually found growing in this manner in the wild state. No orchard is complete without at least a few plums.

There are three distinct classes that are grown here, viz.:

Native, or those from our wild species found growing along streams everywhere.

European-Those introduced from Europe and called Tame or Domestic Plums.

Japanese-A species recently introduced from Japan from which have sprung many excellent kinds. We are growing the most valuable varieties of the three different species.

First Class Trees $\$ 1.00$ each; $\$ 9.00$ for 10 .

\section{Japanese Varieties}

ABUNDANCE-Large and showy; beautiful amber color, turning to bright cherry-red when ripe. Flesh light yellow, tender, juicy and delicately perfumed. Ripens in July.

BURBANK - Large, roundish fruit, bright red when ripe. Flesh is yellow, sweet; of excellent quality and has a pleasant odor. The tree is hardy and bears very freely of this delicious fruit.

RED JUNE-One of the best Japanese plums; ripens before the Abundance; fruit good size; brilliant red; one of the best extra early plums.

\section{European Varieties}

DAMSON-A very productive and popular old variety, bearing quantities of medium-sized tart fruit, dark purple when ripe, covered with a heavy blue "bloom." One of the best plums for canning and preserving. Ripens in September.

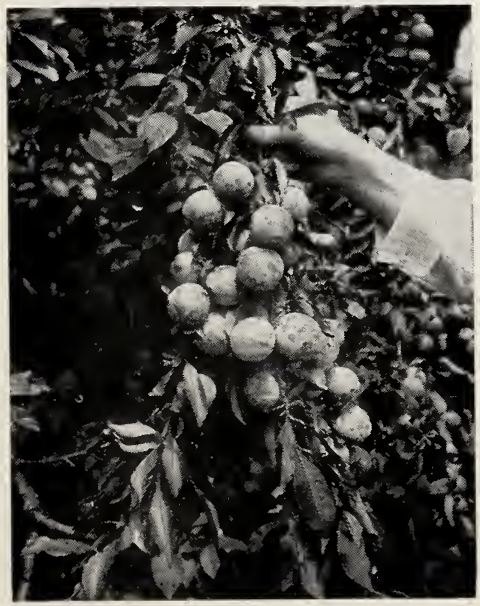

FELLENBERG (French or Italian Prune) A desirable late Plum; oval; freestone. The purple fruit is juciy and delicious, and is excellent for drying. Ripens in September.

GREEN GAGE-A fine, handsome Plum of exceptionally large size. Very desirable in many ways; for home use or market. Fruit greenish in color.

\section{Native or American}

WILD GOOSE-Old and widely planted variety; light red; very early. Season. July 15 th.

WISCONSIN RED-Also called Miner, very large dark red plum; flesh solid, sweet and tender; tree an annual bearer. Begins to ripen about the first of September, and lasts for over a month.

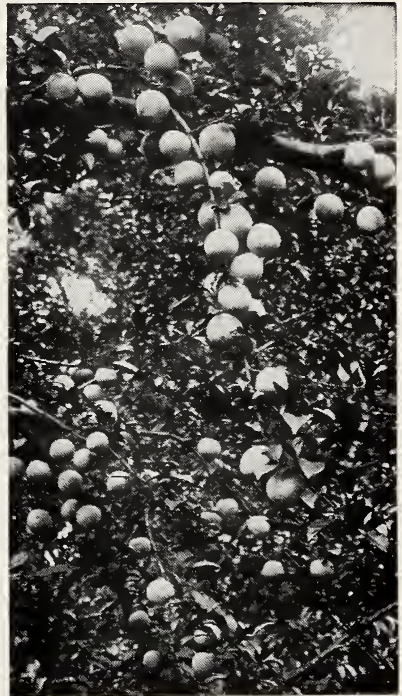

Burbank

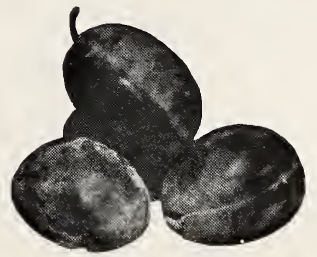

Damson

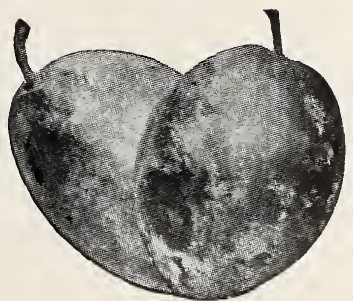

Green Gage 


\section{Grapes}

The fruit of the Grape has greatly increased in popularity since the Volstead Act was established. It may be that the "booze fighter" has found that the fruit of the vine when properly aged will take the hair off his teeth without knocking both eyes out.

The fruit of the Grape has been very popular with the human race ever since our Great Grandfather Noah planted that memorable vineyard after the great flood, being one of the oldest mentioned fruits in Sacred History. It is the most wholesome of all the fruits, and the most highly esteemed for its many uses.

There is no fruit that will grow and take care of itself as will the grape if given a start. It will climb over any other tree or building that it can get hold of, and the higher it climbs the better flavor its fruit. And there is no fruit that will yield a richer harvest if given proper care and pruning.

There are a number of different kinds with various flavors and time of ripening so one can have them fresh from the vines from August to October. The kinds offered are all well known standard varieties and fully tested for hardiness and bearing quantities in this region.

Grape Vines may be sent cheaply and quickly via Parcel Post. and where this mode of delivery is desired the exact amount of postage required will be given on request. Ten cents will pay postage on ten vines in the first and second zones.

\section{Agawam}

Bunch large, compact, shouldered; berry large, dark red flesh tender, juicy, vinous, and of good quality; keeps well. 40e each: $\$ 3.50$ per 10 .

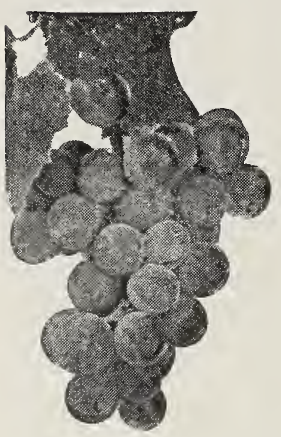

Concord

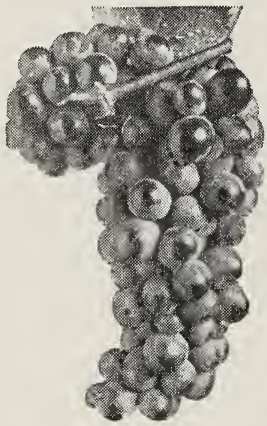

Agawam

\section{Concord}

The fine old market leader, with handsome clusters of large luscious fruit. Entirely hardy and productive. Succeeds well over a great extent of country One of the best known grapes grown. Price, each 25c; per 10 $\$ 2.50$.
The vines we have to offer are all twoyear-old, grown from cuttings taken from bearing vines, and are first class in every particular.

\section{Moore's Early}

Hardy variety bearing large berries with heavy blue bloom. Valuable on account of its ex treme earliness. Ripens first of August. $40 \mathrm{c}$ each: $\$ 3.00$ per 10 .
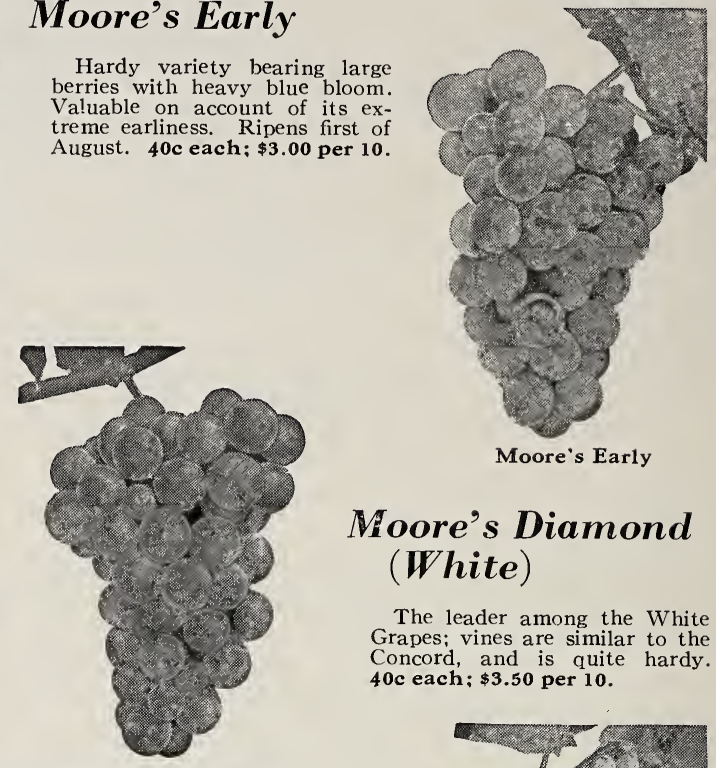

Moore's Diamond (White)

The leader among the White Grapes; vines are similar to the Concord, and is quite hardy. $40 \mathrm{c}$ each: $\$ 3.50$ per 10 .

Moore's Diamond

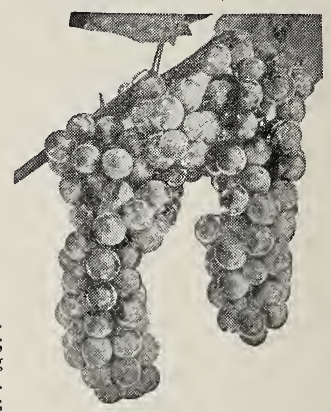

Niagara

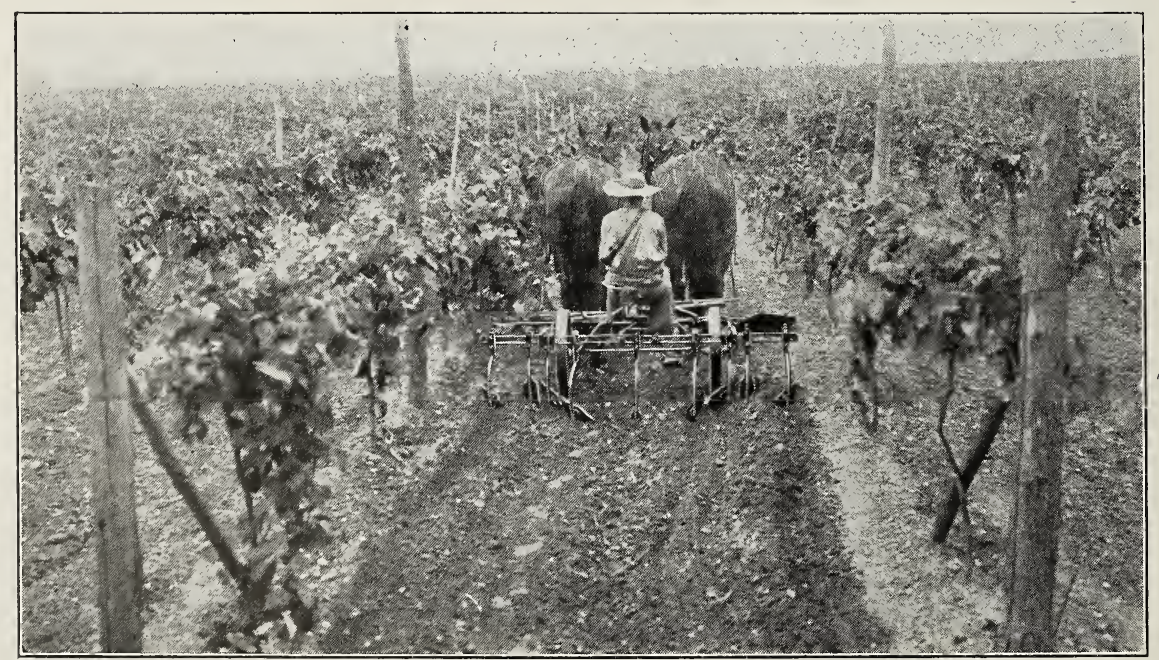

By giving your Vineyard such care it will repay you many times 


\section{Currants}

Like all other small fruits, the Currant needs a rich soil and high culture to get the best results. Grown on a poor soil and in a neglected condition, the fruit will be so acid as to be almost unfit for use, while the fruit of the same kinds

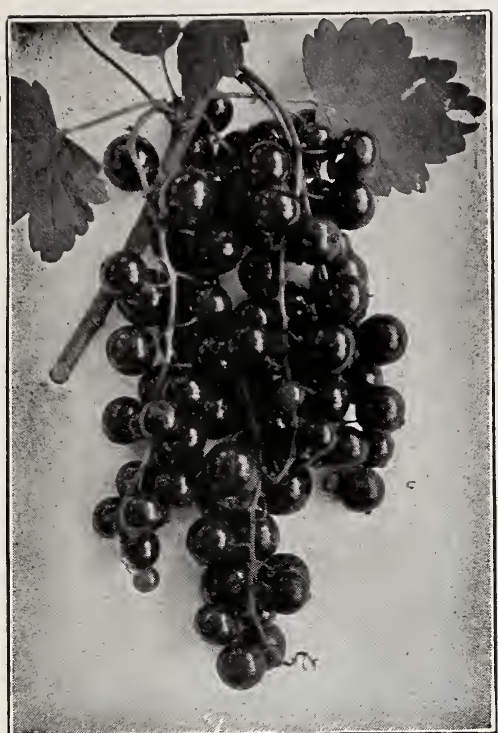

Black Champion grown under favorable conmost refreshing flavor. On account of the long season of ripening, which extends from early in May until September, and the many ways it may be used, it should be included in every garden.

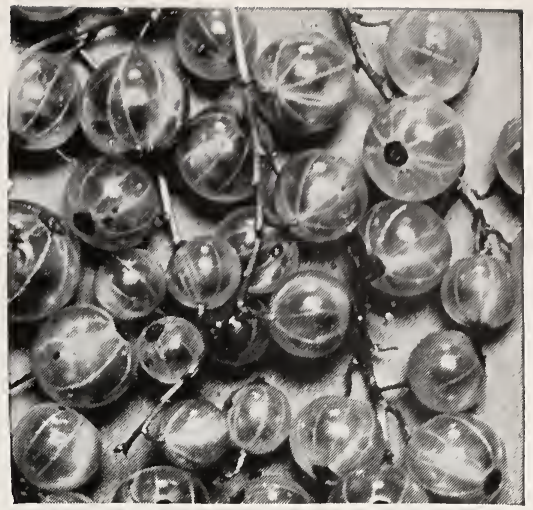

\section{Varieties}

Cherry

CHERRY - Berries sometimes more than half an inch in diameter, bunches short, vigorous and productive when grown on good soils

BLACK CHAMPION-Very productive; large bunch and berry; excellent quality; strong grower. $35 \mathrm{c} \mathrm{each}$.

WHITE GRAPE-Bush vigorous, somewhat spreading, productive. Clusters long; berries large to very large, averaging large; of very attractive color, mild flavor, and good quality. A good table variety. $35 \mathrm{c}$ each.

\section{Our 41 years of business} is your guaranty.

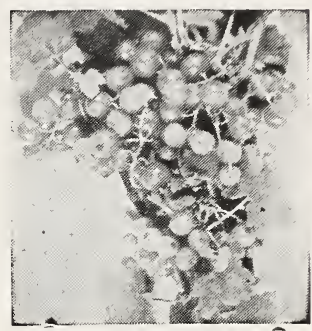

White Grape

\section{Gooseberries}

One of the valuable native fruits, and of the most easy culture. They will grow and do well in most any situation and seem to do as well in a fence corner or along the hedge, as in a cultivated spot. It is the first fruit from the garden in the spring, and may be had in fresh condition from the bushes till the first of September or later.

Many people are prevented from growing either Gooseberries or Currants on account of the currant-worm that eats the foliage and prevents the fruit from maturing. These pests are the easiest controlled of any of the insects that feed on the foliage of plants and trees. The worms go into the chrysalis state in the ground under the bushes and the eggs are laid on the leaves near the base on the inside of the bush. The small worms commence to feed as soon as the leaves are developed. During their early existence they are not noticed, but in a few days of warm weather they spread all over the bush and then seem to eat ip every leaf in a day. The remedy is to sprinkle the bush with water to which a little Paris-green has been added-iust enough to give it a sea-green color-as soon as the leaves are fully grown, and repeat the dose in a week or ten days, to make sure of the worms.

HOUGHTON-An American variety; clear red when fully ripe; very prolific and profitable. $20 \mathrm{c}$ each; $\$ 1.75$ per 10.

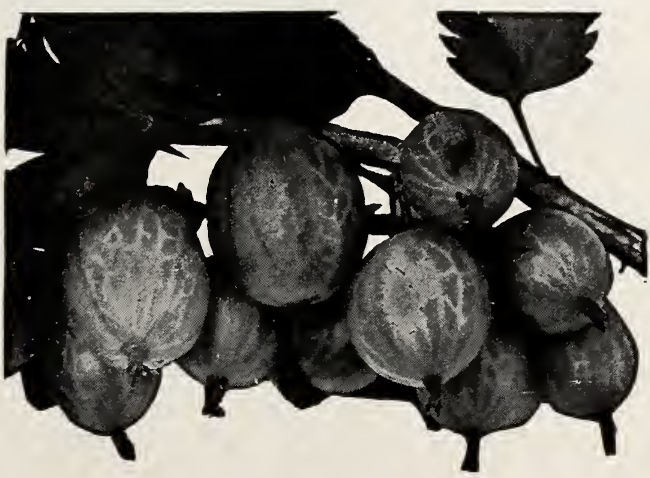

Houghton Gooseberries
DOWNING-Native variety; fruit large, round light green with distinct veins, juicy and tine flavored skin smooth. Bush very productive. 25c each: $\$ 2.00$ per 10 .

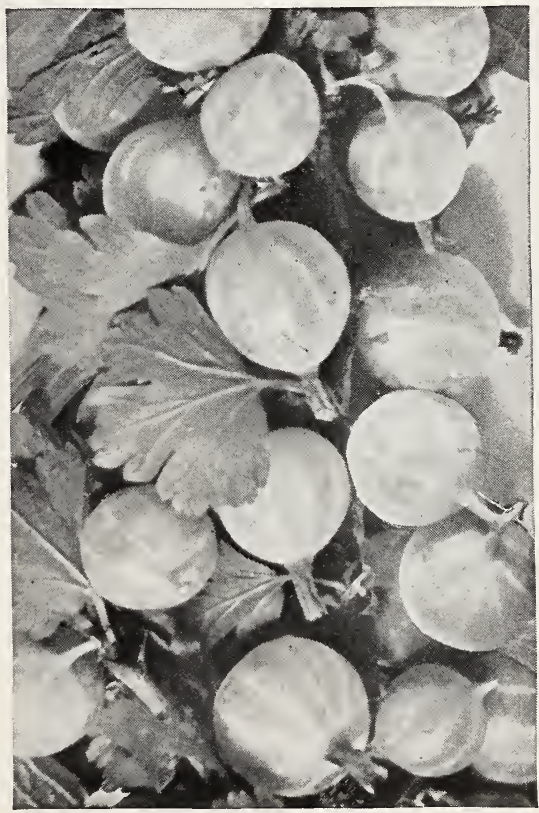

Downing Gooseberries

There is nothing that adds as much beauty or gives such a degree of refinement to a home for as little out-lay of work and money as a proper planting of trees, shrubs, vines and flowers. 


\title{
Raspberries
}

The Raspberry is one of the early garden fruits and of the most easy culture. It may be found growing in a wild state most anywhere along the edge of a grove or thicket, or along the hedges and fences. Being a native it produces bountifully under cultivation. And the fruit finds a ready sale in the markets at nearly double the price of any other fresh berries.

It is necessary to renew a plantation every few years as the crowns become old and infested with anthracnose or raspberry scab causing the fruit to become small and insipid.

Blackcaps-Price each $10 \mathrm{c}$; per $10 \mathrm{z5c}$; per $100 \$ 5.50$.

Redcaps-Price each $15 \mathrm{c}$; per $10 \$ 1.25$; per $100 \$ 8.00$

Reds that sprout from roots-Each $7 \mathrm{c}$; per 1050 ; per $100 \$ 3.50$.

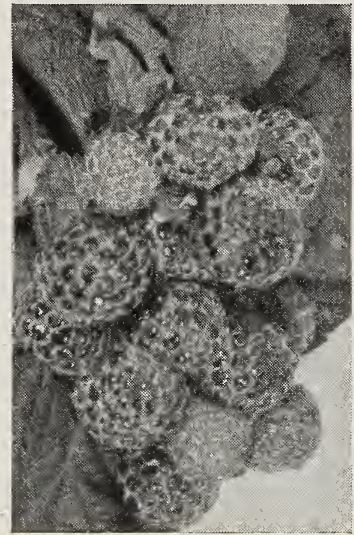

\section{Plum Farmer}

A large Blackcap of extra fine quality of fruit. Canes hardy and free from disease and a vigorous grower. The best of the Blackcaps.

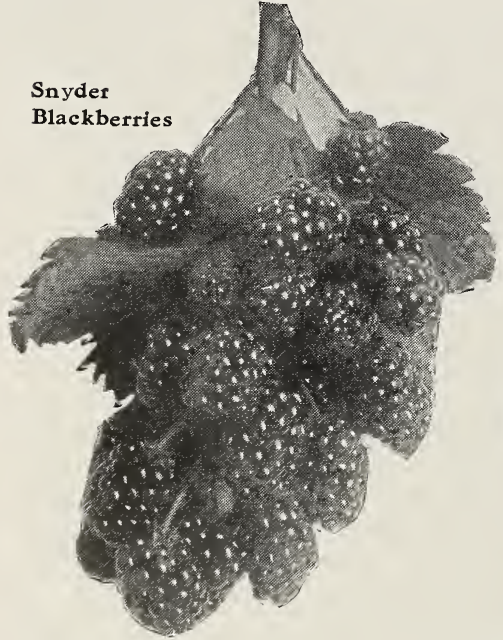

The Red Raspberries or those that sprout from the root should be planted closer in the row, and all suckers that come up between the rows should be cut out. This will give more strength and vigor to the growing canes. This class of raspberrp requires no pruning further than taking out the dead canes. This has to be pruning further than taking out the dead canes. This has to is thone with all raspberries as the canes only live two seasons, that is they grow up one year and bear and die the next. All Raspberries

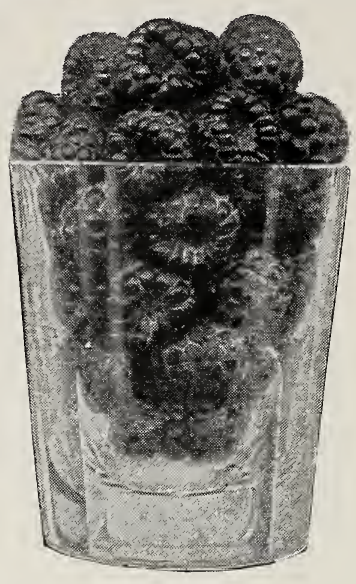

\section{Cumberland}

A healthy, vigorous grower, throwing up stout, stocky, well branched canes that produce immense crops of magnificent berries. Fruit very large, firm, quality about the same as Gregg, keeps and ships as well as any of the Blacks. The most profitable market variety. Mid-season.

\section{Cuthbert}

Large, bright scarlet or crimson, excellent quality; firm, juicy and refreshing, hardy and productive. The very best of the kinds that sprout from the root. (See illustration on the right.)

\section{Blackberries}

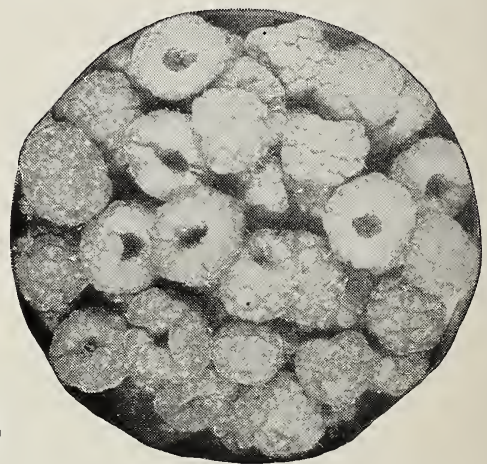

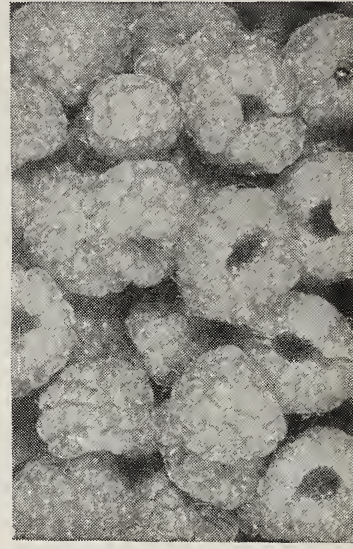

\section{Columbian}

Redcap of large size. Canes strong and very productive. The fruit is dark red and of fine flavor.

\begin{abstract}
Blackberries require about the same culture as Raspberries and follow them closely in time of ripening. The rows should be from 7 to 8 feet apart and the new shoots pinched off at the ends when they get about three feet high, which will give short and stocky bushes that will stand up well under a load of fruit. This, 1ike the Raspberry, is a native fruit and readily responds to high culture. Have tested a gond many different kinds and have found the Snyder to be the most valuable for the north. Illustrated on the left. Price per 10 plants $75 \mathrm{c}$ : per $100 \$ 5.00$.
\end{abstract}

Before making extensive plantings you should have our landscape men make a survey of your grounds and furnish you with a properly worked-out design for beautifying them. We make surveys and submit sketches in blue-print together with an estimated cost of planting. We do everything from start to finish and save you both money and regrets. 


\section{Strawberries}

Strawberries will produce more fruit to the square rod and in less time than any other fruit we can grow. And is one that grows wild in every section of the country from Alaska to Florida. It has always been a mystery to me why so many people do not raise this most refreshing and early fruit. A few square rods will produce all that one family can possibly use.

Put out a planting and see how your neighbors and friends will love you. This alone is worth the bother and expense of growing a patch.

Altho plants may be set most any time of the season, the best time is early spring. Setting after the plants have made a considerable growth, makes it more difficult to get a stand.

However, Strawberries may be transplanted at any time during the summer and fall. If the weather is hot and dry, by the proper shading and watering a bed can be established. Still early spring is the best.

Our Soil is especially suited to the development of Strawberry plants and our plants are much larger than are usually sent out. Our stock is cultivated entirely for the production of plants which are kept pure, carefully graded, handled and packed. $\$ 10.00$.

\section{Dunlap}

A perfect-flowered variety that fruits without being planted with other kinds. Is proving to bethe most valuable Strawberry yet int is now planted all over the U. S., and is a favorite every where. The berries are very large, bright red, well formed great plant producer, it does not require as many plants to set a row as other kinds.

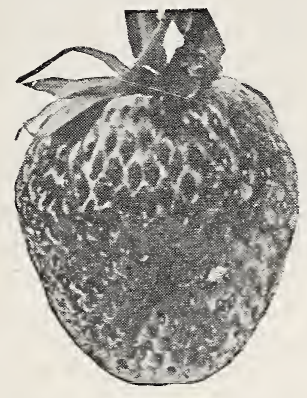

\section{Haverland}

A large pointed berry, light colored and fine-flavored, and ripens over a long period. The bloom is imperfect and requires some perfect flowered kind for fortilization. But when the blossoms are well fertilized it blossoms are well fertilized it produces a wonderful crop. It lap as a fertilizer.

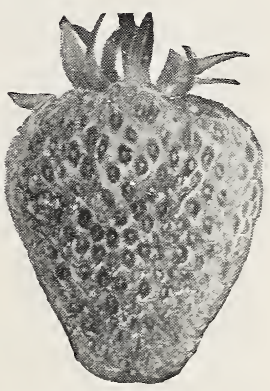

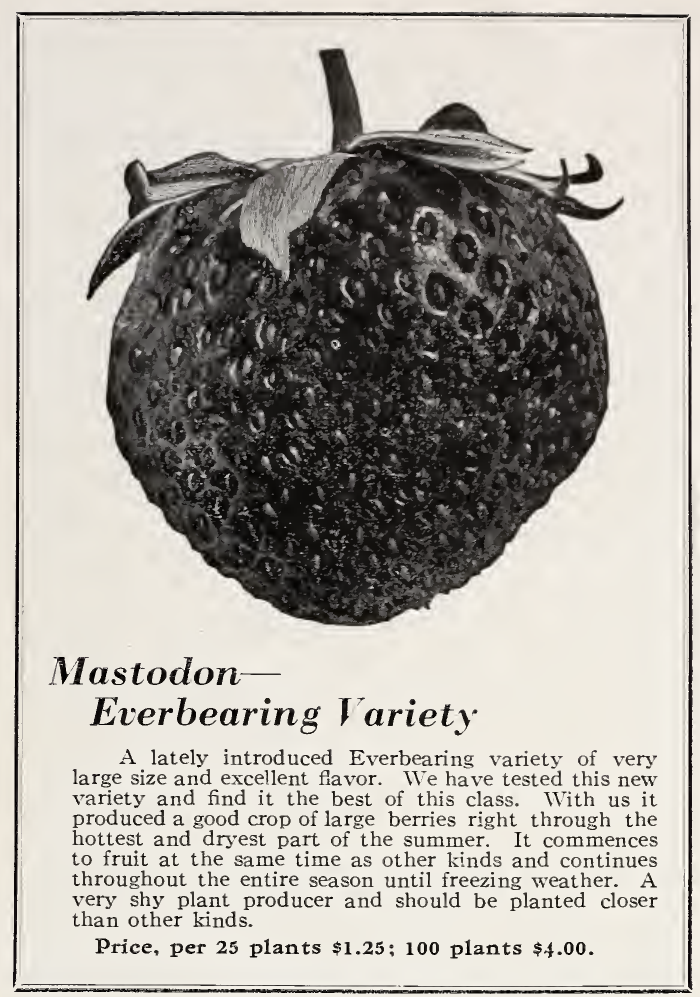

\section{Brandywine}

A very late bearing variety, extending the Strawberry season more than a week. The fruit is medium large and dark red, high flavored. Not as prolific or profitable as some other kinds. Its late season and fine flavor makes it desirable.

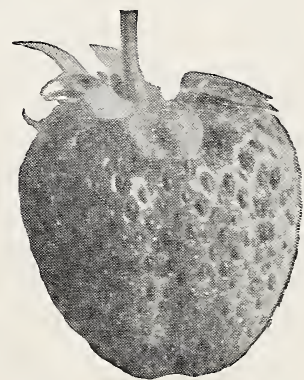

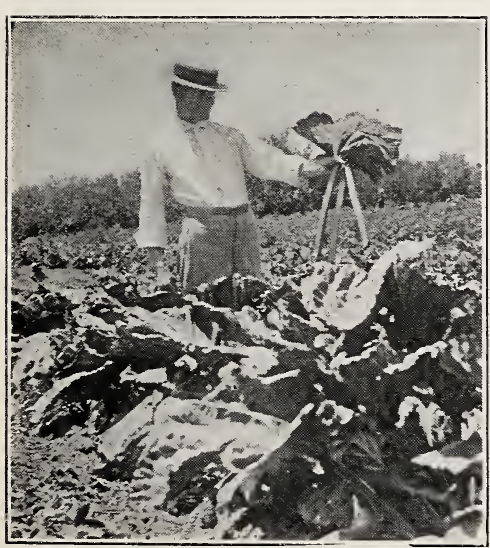

Rhubarb

\section{Garden Roots}

\section{Asparagus}

The earliest vegetable from the garden and of the easiest culture. A planting once established will grow and produce abundantly for an indefinite period with the least attention. Price for strong roots, each $5 \mathbf{c}$ per $1050 c$; per $100 \$ 3.00$.

\section{Rhubarb}

One of the earliest sauces from the garden, and on account of its coming before anything else in the spring, is eagerly sought. Strong Roots of extra early kind, each 20c: per $10 \$ 1.50$.

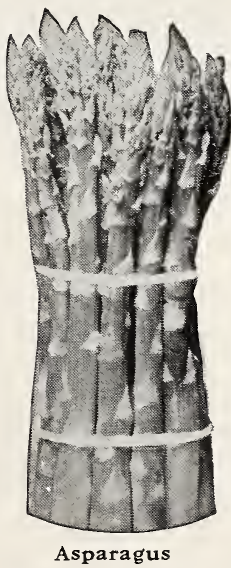

A business conducted in the same place for 41 years with an ever increasing trade is proof enough of reliability. 


\section{Greenhouse Department}

\section{Home Nursery Greenhouses \\ La Fayette Illinois \\ GAAR INGELS, Proprietor}

Our equipment for this Department is modern and up-to-date. We now have about 20,000 square feet of glass devoted to the growing of all the popular kinds of cut flowers and potted plants. A trial order will convince you that we grow "quality stock."

Large stock suitable for window boxes and baskets. Bring them along and we will fill them for you

Cut Flowers for All Occasions-We ship only fresh cut flowers of our own growing and they are not to be compared with flowers held perhaps for a week in a retail store. You buy direct from the grower and pay only one profit. We guarantee safe delivery by Parcel Post.

Carnations-Red, white light and dark pink, \$1.00 per doz. Sweet Peas-Lavender, pink, orange. Bunch of 25 stems, 75c. Roses-Pink or red. \$2.00 per doz.

Calla Lilies-Extra large. $\$ 4.00$ per doz.

Snapdragon-White, pink, bronze or salmon. Long stems. $\$ 1.50$ per doz.

Other flowers in season.

Note-For making up Sprays with green and tying with Chiffon, 50c additional. Emblems, Wreaths, Floral Designs, etc. according to size, $\mathbf{\$ 5 . 0 0}$ and up.

Cut Flowers ordered for Holidays, 30 per cent higher.

Order by phone or mail. Day and night service.

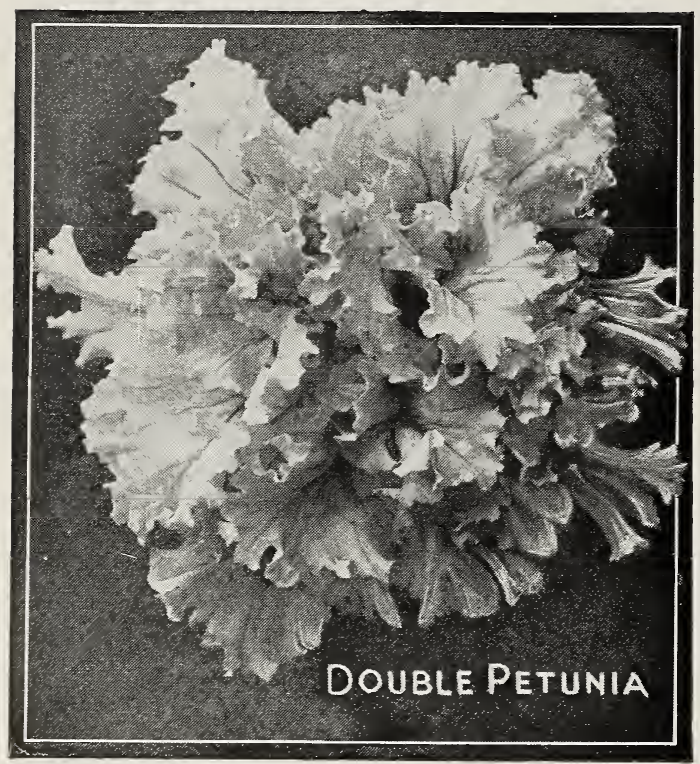

\section{Bedding Plants}

Ageratum-Dwarf, blue, fine for edging. Alternanthera (Joseph's Coat) - Three col-

ors, red, pink or yellow. Fine for edging

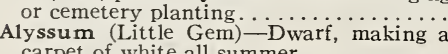

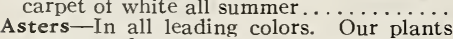

are grown from the best seed obtainable, in

named varieties of Comet and branching

types. From early to late kinds........

orchid-flowering varieties and the very

best of their colors.

Mrs. Alfred Conrad-Salmon-pink, green

King Humbert-Orange-scarlet, bronze

The President-Scarlet, very large and

The President-Scarlet, very large and
showy, green leaves.

Yellow King Humbert-Deep yellow

Any of above varieties well established

in pots.

$\begin{array}{rrr}\begin{array}{r}\text { Pot, } \\ \text { incl, }\end{array} & \begin{array}{l}\text { Each. } \\ \$ .10\end{array} & \begin{array}{l}\text { Doz. } \\ 2\end{array} \\ 2 & .60 \\ 2 & .05 & .50 \\ & & \\ & & \\ 2 & .10 & .60\end{array}$

$\begin{array}{lll}3 & .20 & 2.00\end{array}$
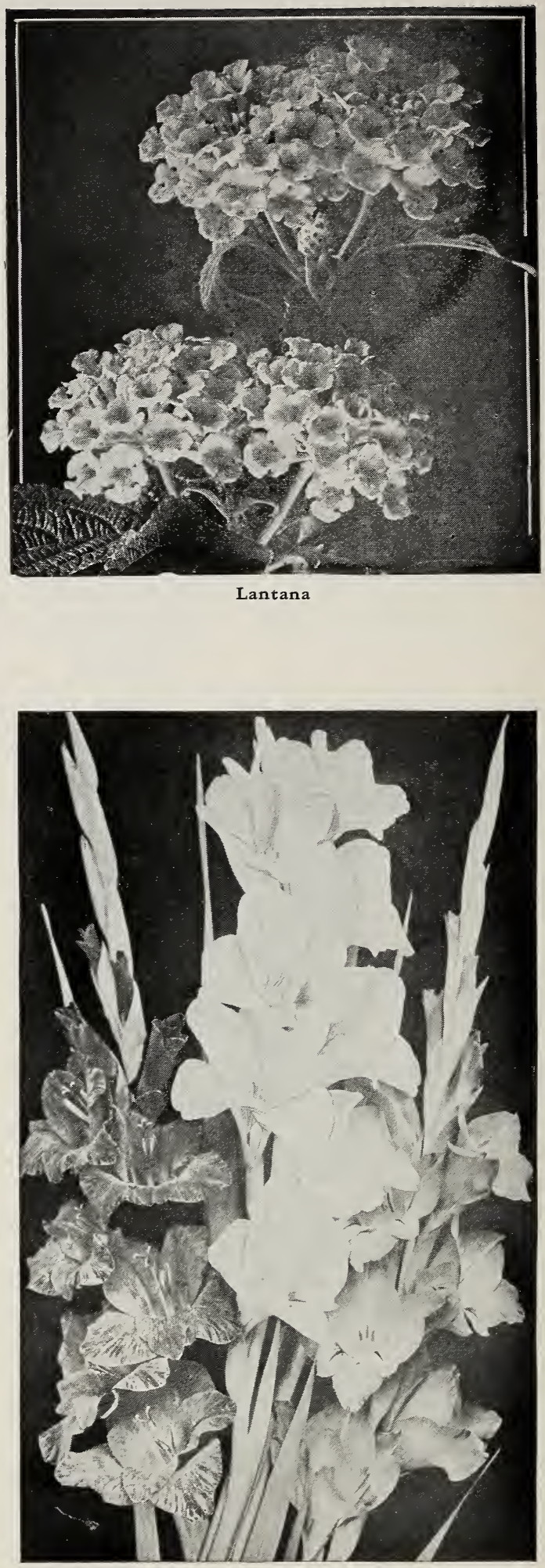

Lantana

Gladiolus 


\section{Greenhouse Department,}

\section{Continued}

Coleus (Foliage Plants) - Finest assorted Pot

Centaurea (Dusty Miller) - Fine for borders or in window boxes; leaves fern-like, of silvery-gray color

Dracaena Indivisa-Long, narrow, green leaves, palm-like. Suitable for center plant in baskets, vases or boxes........ Ferns -

(Boston)-Large specimen plants.

Asparagus Plumosa-Fine feathery leaves Asparagus Sprengeri-Valuable for hang-

ing baskets and window boxes.....

Geraniums-Assorted colors in the newest and best kinds. (3-inch $15 \mathrm{c}$ each; dozen $\$ 1.50$ ).

Gladiolus (Bulbs)-Best up-to-date, largeflowering, all colors, twelve different kinds

Heliotrope-Dark blue, very fragrant, always in bloom. Should be in every garden

Ivy (Parlor Ivy) - Fine for baskets or boxes .

Lantana-A shrubby plant; verbena-like flowers; perpetual bloom. Varieties, red, pink or orange.

Moon Vine--Large, white, fragrant flowers; rapid grower.

Pansy-Grown from seed of Steel's Mastodon-the best and largest strain of Pansies

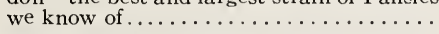

Pelargoniums (Martha Washington Geranium)-Four different ever-blooming

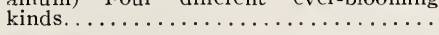

Petunias-One of the most satisfactory blooming plants we have. Will make a solid mass of color throughout the summer. Only the best kinds, viz.

Rosy Morn-Pink.

Blue-A good color to plant with above.

Diener's Ruffled Giant.

Star and Large Doubles.

Separate colors.

Blooming size.

Phlox Drummondi-Very showy, in a great variety of colors. Blooms continually till frost. Very dwarf grower, making a neat border.

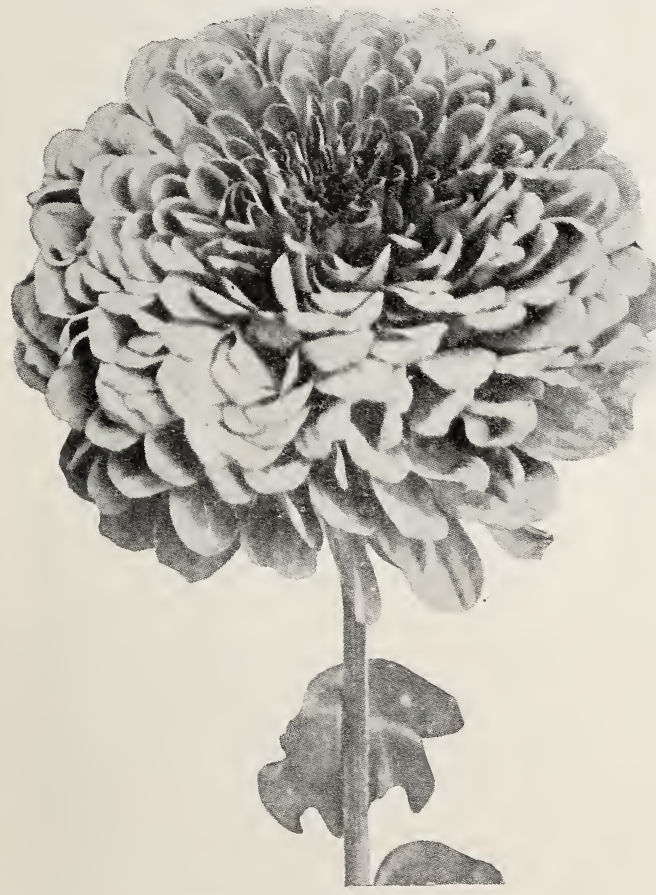

Giant Dahlia-Flowered Zinnia

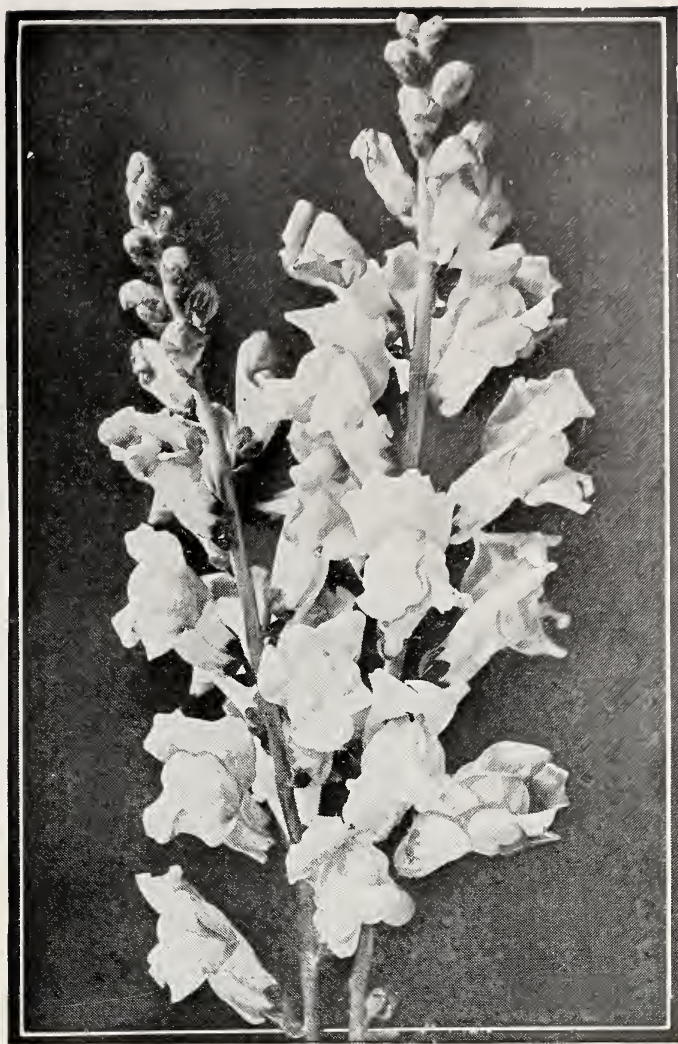

Snapdragon

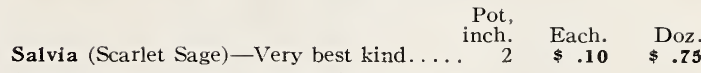
Snapdragon-Best named kinds. Red, yellow, white, pink, apricot, salmon or ${ }^{2} \quad .10 \quad .60$

Verbenas-Red or mixed colors. Always in bloom....................... 2 .10

Vinca-Vine with variegated, green and white leaves; the very best for hanging baskets or boxes................. $3 \quad .15 \quad 1.50$

Vinca, Rosea (Periwinkle)-Waxy foliage, pink and white flowers; very satisfactory. Zinnia-Bodger's true strain of Giant Dah-

\section{Vegetable Plants}

Cauliflower.......................

Pepper-Mangoes and Pimentos.

Cabbage-Early Jersey Wakefield.

Cabbage-Danis

Eggplant-Purple (Potted)...........

(per $100 \$ 1.00)$

Tomatoes-Bonny Best (Improved Earliana), trans-

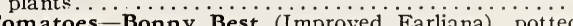
plants.

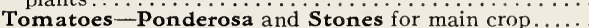

Tomatoes-Ponderosa and Stones for main crop, transplants.

Note-Our vegetable plants are grown from the best seed obtainable. Try them and note the difference.

Flower and Plant orders should be sent direct to this Department.

\section{Home Nursery Greenhouses La Fayette Illinois}




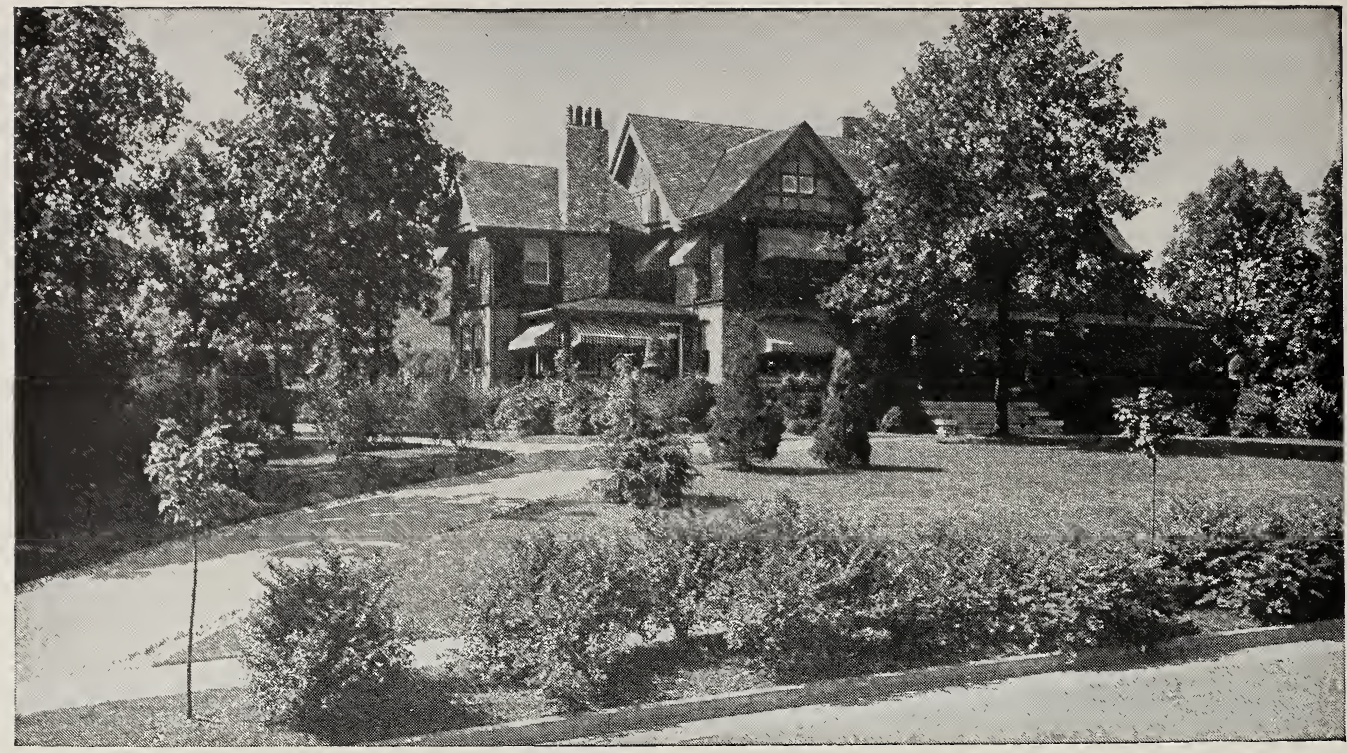

Permanency and individual substantiality`are reflected through well planted home grounds

\section{Ornamental Department}

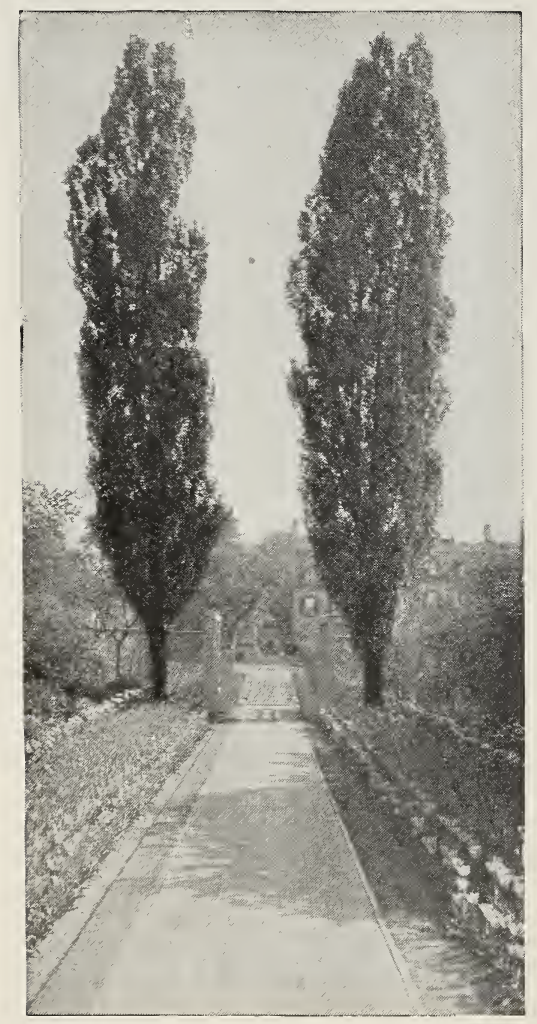

Lombardy Poplars

LOMBARDY POPLAR-Very tall rapid-growing tree with spire-like habit. Very suitable for planting in landscape designs in connection with more spreading kinds. Splendid for screen and acrent planting. 10 to $12 \mathrm{ft}$., each $\$ 2.00$.

There is nothing about a homestead in the country or residence in city or village that reflects the culture and renfinement of the owner as do well-kept and judiciously planted grounds. The planting also adds selling value as well as beauty and comfort.

In the development of the Central West the first and most important thing to the home builder was to get the home, and little attention was paid to the beautifying of the home grounds. Now the land is practically all developed into farms with convenient and substantial buildings, and the owners are beginning to think about beautif ying their homes by the planting of ornamental trees, flowering shrubs and plants.

The demand for ornamental trees, shrubs and plants has greatly increased the past few years and to meet this demand we have greatly enlarged our plantings in this department and enlarged our facilities for propagating this class of stock, which corisists of such kinds as are hardy and desirable and represent a great variety of colors both in blossom and foliage, as well as in habit and growth, and we are able to supply these in large quantities.

Where large or small estates are to be beautified or grounds laid out, such as parks. playgrounds, institutional and ciub grounds, cemeteries, etc., we send a landscape architect to survey same and furnish complete plans and specifications for the proper planting, location of walks, drives, etc.

Our stock of Ornamentals consists of the very best and hardiest kinds suitable for this latitude and the list contains over 150 different kinds of Shrubs and Hardy Plants. And our extensive list of Evergreens contains all the most desirable and hardy for this latitude.

With this large list and our splendid stock we are in position to execute any Landscape Job in the best possible manner. Having our own stock to select from, we are not handicapped by having to send away for any stuff, in beautifying grounds, and are able to give our customers better satisfaction.

You will find it far more satisfactory to have your Home Grounds Landscaped by a firm that is able to make the design and execute every detail from start to finish than to entrust the job to two or more firms working independently. You save both time and expense.

Remember, it is "Quality" that you get when dealing with the Home Nursery.

\section{Shade Trees}

CATALPA SPECIOSA (Hardy Catalpa) - A rapid grower, soon becomes a large tree. The large dark green leaves makes a dense shade. Flowers very showy, in large panicles, white tinged with violet and dotted with purple and yellow. A very ornamental tree, absolutely hardy. 8 to 9 feet. Each $\$ \mathbf{1 . 5 0}$.

ELM (American White)-A splendid native tree of great size and wide spread, with graceful drooping branches. Classed among the rapid growing trees and is not easily damaged by storms. On account of its wide spread is one of the best for streets and parks. 8 to $10 \mathrm{ft}$., each $\$ 2.50 ; 10$ to $12 \mathrm{ft}$., each $\$ 3.50$.

MAPLE, SOFT-Well known rapid growing native tree valuable where quick shade is wanted. It was among the first trees planted for shade by the early settlers 50 to 75 years ago as there was no other native tree so beautiful, so easily transplanted or made such quick shade. Altho not as long lived as the Oak or Elm, they make a beautiful tree for at least the first 25 years. 9 to $10 \mathrm{ft}$.. each $\$ 2.00$.

MAPLE, HARD (Sugar Maple)-Makes a round, dense top, medium rapid growth and one of the best for shade. Rather slow about getting started after being planted, but when once established makes very rapid growth. The leaves give beautiful autumn tints in the fall of yellow and scarlet. Has no equal for shade. 12 to $14 \mathrm{ft}$., each $\$ \mathbf{5 . 0 0}$. 
The public library of Toulon, Illinois, showing a setting of trees and shrubs designed and planted by the Home Nursery and serves as an example of what might be done with any public building at little cost.
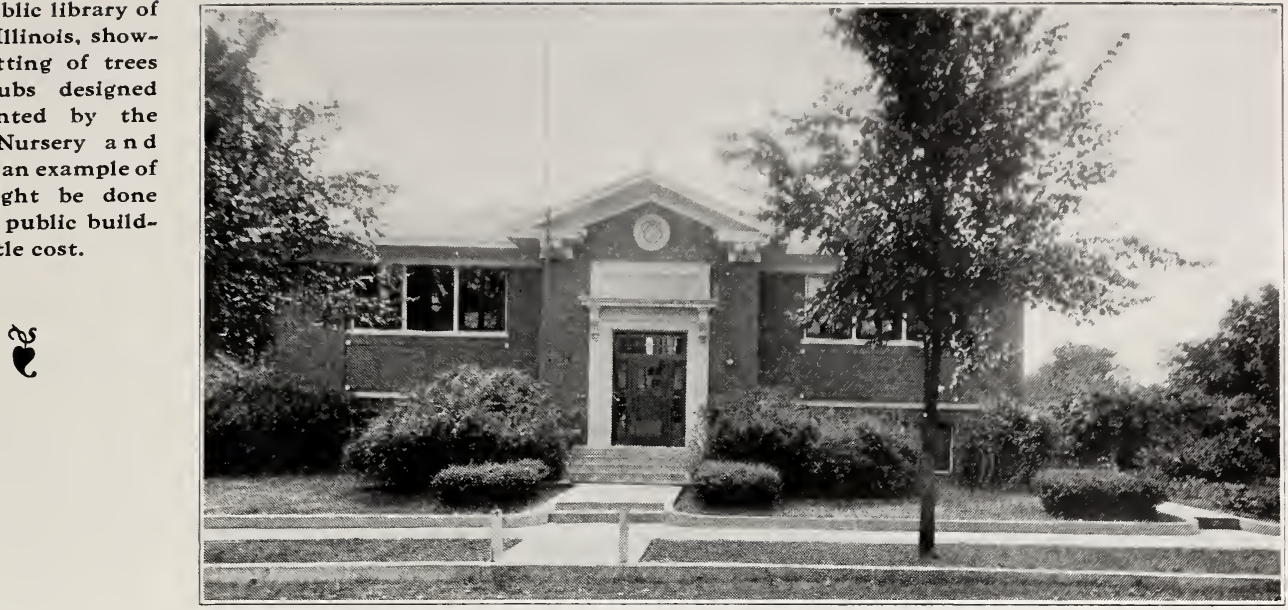

\section{Shade Trees, Continued}

MOUNTAIN ASH-Hardy tree, head dense and regular, beautiful iern-like green foliage, covered from July to winter with clusters of bright red berries. The combination of foliage and clustered fruits makes it a very beautiful tree for lawn planting. 5 to $6 \mathrm{ft}$., each $\$ 1.50$.

RUSSIAN MULBERRY-Very hardy, round-topped tree. Rather small tree of bushy growth, bears full of small red and white berries much sought for by the birds. Suitable for bird gardens or chicken yard. 6 to $\mathbf{z ~ f t . , ~ e a c h , ~ \$ 1 . 0 0 . ~}$ RED BUD (Judas Tree)-A small-growing tree about the size of the wild plum, of irregular form, with heart-shaped leaves. The branches are covered with bright pink blossoms very early in the spring before the leaves appear, which gives its name Red Bud. Fine for massing with other large Shrubs for an early spring color effect. 3 to $4 \mathbf{f t}$., each $\mathbf{7 5 c}$.

WILLOW (Laure1-Leaved)-Makes a dense round-topped medium sized tree with broad glossy, dark-green leaves that shine conspicuously in the sunlight. Introduced from Russia. 6 to $8 \mathrm{ft}$., each $\$ 1.50$.

\section{For Formal Planting}

CATALPA BUNGEI (Umbrella Catalpa)-A bush form of Catalpa from China. When grafted on stems 6 to 7 feet high it makes an umbrella-shaped top without pruning. This is the dwarf round-headed tree, frequently seen and used primarily for producing formal effects. 2-year heads, $\$ 3.00$ each.

\section{Weeping Trees}

The Weeping Trees lend grace and beauty to ornamental grounds and may be planted singly in open situations where they will fully develop. The following list contains the most hardy and desirable of this class of trees:

TEA'S WEEPING MULBERRY - One of the most perfect weeping trees yet introduced. With long, slender, willowy branches reaching the ground; full of fruit during the early part of the summer. The foliage is bright glossy green. Price, each $\$ 3.50$.

CAMPERDOWN WEEPING ELM-One of the finest weeping trees for the lawn. With broad foliage and branches drooping gracefully to the ground. Price, each $\$ \mathbf{3 . 0 0}$.

WEEPING WILLOW (Babylonian)-A most graceful tree of large size. Its fresh, bright green tint and long, wavy branches make it very attractive. Price, each $\$ 2.00$.

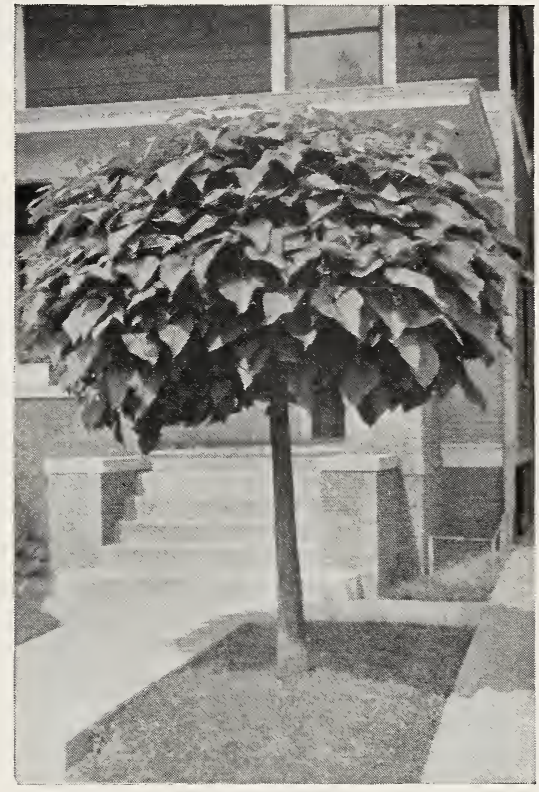

Catalpa Bungei

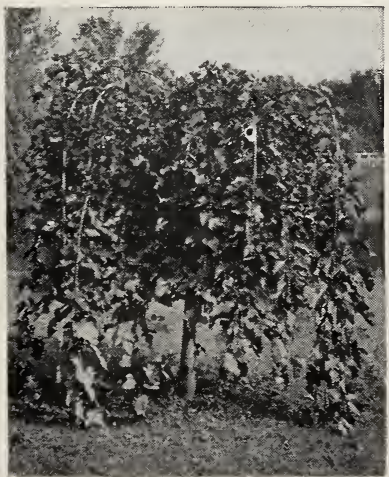

Tea's Weeping Mulberry

\section{Suggestions on Planting}

In planting, due regard should be paid to the space available, and trees and shrubs should not be planted at random. Nothing is more handsome than a fine, well-cut lawn, with trees and shrubs planted along the drives leading to the house and other buildings. The background for a large lawn should be of the different varieties of larger growing trees, with groups of specimen trees in the foreground. Most shrubs are at their best planted in beds, either all of one variety or with several varieties so arranged that the higher growing ones will form the center with those of lower growing habits massed around them. These plants should be thoroughly cultivated and annually pruned. It is not well to plant so few that years must pass before a good effect is produced, but a surplus should be planted at first and this gradually taken out.

Vines should be planted near the house and allowed to clamber on it or may be trained with fine effect over arbors or stakes placed in the lawn.

"Give fools their gold, and knaves their power,

Let fortune's bubbles rise and fall;

Who sows a field, or trains a flower,

Or plants a tree, is more than all."-WhitTiER. 


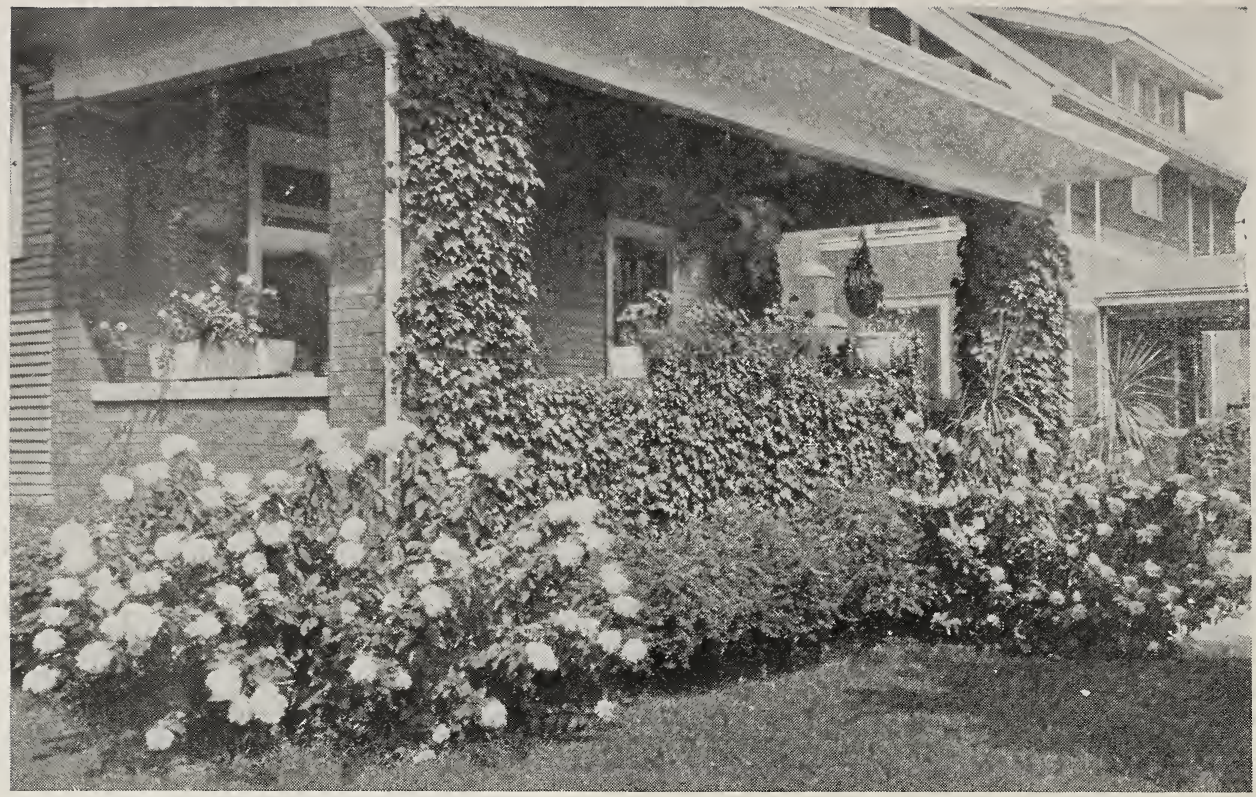

Hydrangeas blooming in the yard; Ampelopsis Englemanni climbing over porch; specimen plants of Japanese Barberry growing between the Hydrangeas; any or all of these items can be supplied by us and are listed in this catalog. You will find plants for porch boxes, etc., listed under "Greenhouse Department."

\section{Hardy Ornamental Shrubs}

Nature is Always Bounteous in her gifts to man and has been unstinted in giving us a great wealth of shrubs with their perfume and flowers, with their varied colored foliage and bright fruit. No one with home grounds either large or small should be without enjoyment of these wonderful gifts. Who can measure the uplifting influence they have upon those that are enraptured by their beauty and fragrance!

They require but little care when once established and grow in size and beauty each year. They are very effective for screens, borders and for grouping on the lawn. There may be had a succession of bloom the entire season by planting the various kinds and many will hang with highly colored fruit during the fall and winter.

There is scarcely a home in country, suburb or town, the beauty and value of which cannot be enhanced by a judicious planting of the grounds, be they large or small; and for this purpose there is no class of plants that lend themselves more readily than the hardy, flowering shrubs. In this part of the West their importance has only begun to be appreciated.

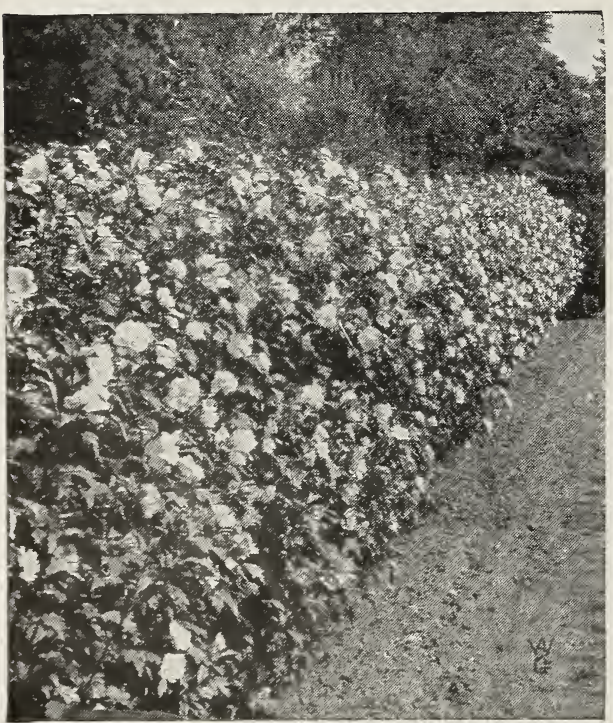

Althea used as a hedge

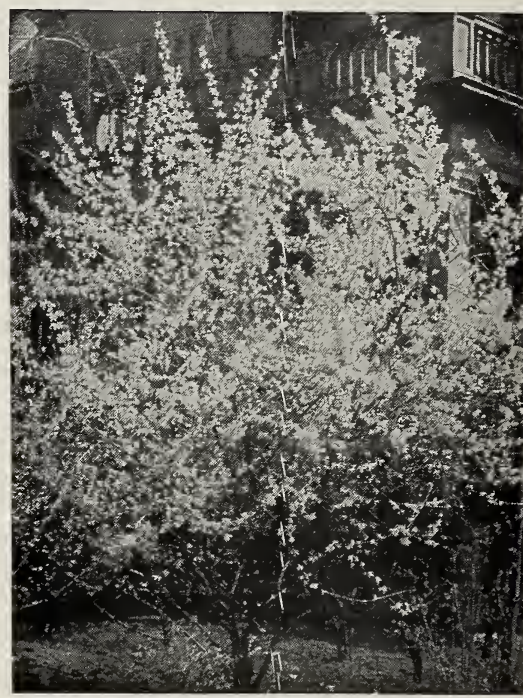

Amygdalus (Flowering Almond)
To meet this demand we have added a number of de sirable hardy mental-leaved ornarieties to our list of shrubs.

ARALIA PENTA PHYLLA (FiveLeaved Aralia)Of $c$ o m a c t, graceful outline, with bright green and shining foliage, attaining a height from 5 to a $\mathrm{x} u \mathrm{ri}$ i $\mathrm{n}$ glossy foliage

adapted to dark shady places, where other shrubs fail. Each 60c. ARALIA SPINOSA (Hercules Club)-Upright growing shrub or small tree with handsome cut leaves 2 to 3 feet long, giving a tropical effect. Flowers white, in enormous clusters in August. A very odd tropical looking shrub. Each 75c.

ARONIA FLORIBUNDA-Attractive, perfectly hardy shrub, preferring moist location, but equally as good in dry soil. Leaves are smooth palegreen, coloring vividly to red in the fall. Flowers are tinted white in numerous sma!l corymbs, succeeded by conspicuous persistent berrylike fruits. Very attractive when in bloom. Very suitable for shady locations. Each 50c.

ARONICA NIGRA-Shrub very similar to the above, but bearing attractive black fruits that hang on until late fall. Each 50c.

AMYGDALUS (Flowering Almond) - Very early spring flowering shrub, gaily in bloom before the leaves appear. On account of the brigh pink color of the bloom it is one of the most attractive of the extra early spring-flowering shrubs. Each 75c. 


\section{Hardy Ornamental Shrubs,}

\section{Continued}

ALPINE CURRANT - A very hardy shrub of dense habit, unfolding very early its bright green foliage, adorned in summer and autumn with bright scarlet berries; it is on of the best shrubs to plant as undergrowth or in shady places. Well adapted to hedging and stands any amount of shearing and shows no shear marks. Makes an ideal solid hedge and holds its foliage until late in the fall Makes a dense, round, conical bush when grown as a specimen. Each $\mathbf{7 5 c}$.

ALTHEA (Rose of Sharon)-Upright growing shrub noted for its profusion of large blooms, much like the tender Hibiscus, blooming late in August until October. Should be planted in a somewhat protected situation in this latitude. Altho it sometimes kills back by the winter, the bloom is produced on the new growth and always has an abundance of bright colored flowers. Each $75 \mathrm{c}$.

BERBERIS THUNBERGI (Japan Barberry)-There is no shrub in existence so generally planted or more practical tor all purposes where beautiful foliage effect is desired than this. It is dwarf growing, uniformly bushy and rounded form, susceptible to formal pruning, with small, numerous leaves densely covering the thorny twigs. These give it paramount importance for use as edging for shrubbery groups; as a foundation screen in front of porches and above all, as a compact, impassable, hardy, low hedge for confining lawns or dividing properties. Autumn painted the foliage crimson-scarlet and bronze, and studs the branches with crimson fruits which hang on all winter. Each $35 \mathrm{c}$; per $10 \$ 3.00$.

BUDDLEA (Butterfly Bush)-One of the most desirable summer flowering shrubs, beginning to bloom in July, it continues until cut by frost. The flowers are of a pleasing shade of violet-mauve and borne in dense cylindrical spikes from 12 to 15 inches in length by 3 inches in diameter. It succeeds everywhere and flowers the first season. Very fragrant, attractive to butterflies, hence its name. Semi-herbacecus, as it usually kills down during the winter but springs from the root four or five feet in height and blooms full. Each $75 \mathrm{c}$.

CALYCANTHUS (Sweet-Scented Shrub)-Old-fashioned Alspice; upright habit, with glossy leaves and chocolate colored flowers, with fragrance of the strawberry. The wood and leaves have a very pleasant, spicy fragrance. Each 50c.

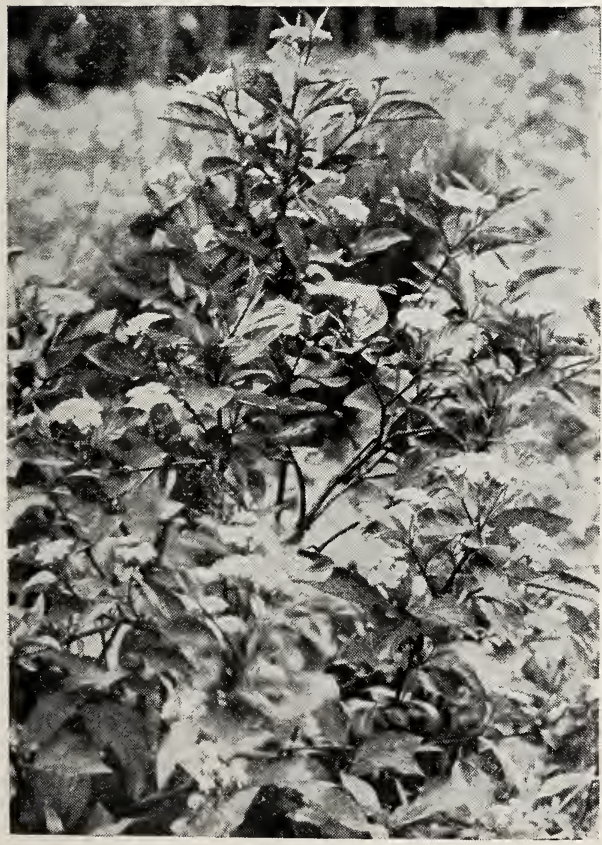

Cornus (Flowering Dogwood)

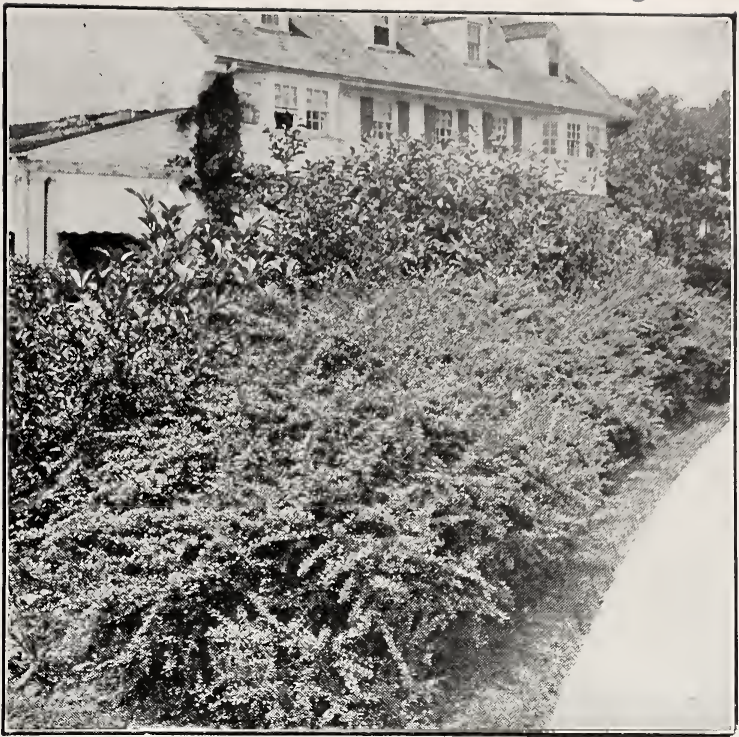

Japanese Barberry

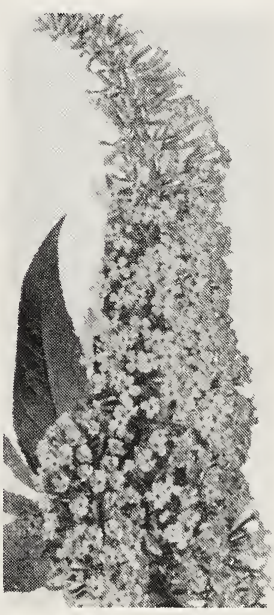

Buddlea
Cotoneaster

COTONEASTER ACUTIFOLIA-A beautiful hardy shrub of recent introduction from Northern China, with spreading, slender branches and beautiful dark-green foliage persistant until into the winter. Very ornamental for hedging, shears well and its beautiful persistant foliage makes it most valuable for this purpose. Each 50c per $10 \$ 4.00$.

COTONEASTER HORIZONTALISHardy variety of compact, spreading. dwarf habit of growth with neat evergreen foliage and very attractive orange-red berries which are set off nicely against the dark green foliage nicely against the dark green foliage and which remain on the plant all of for rockery. Each $\mathbf{7 5 c}$.

If you have grounds you want ornamented with trees and shrubs, write us. We furnish plans and estimates to our customers free.

\section{Cornus (The Osier Doguood or Cornel)}

The Dogwoods are a wonderful group of highly ornamental shrubs, thriving in almost any soil, sun or shade, growing to a height of from 5 to 8 feet, and having the continuous ornamental qualities of white flowers in summer, bright foliage in fall and bright colored twigs and berries in winter, which attract many desirable birds. Note the following varieties:

CORNUS ALTERNIFOLIA-Small white flowers in May, followed by dark blue berries. Foliage bright green; habit quite distinct from the other Cornus. Each $\mathbf{5 0 c}$

CORNUS PANICULATA (Gray Dogwood) - Shrub with rather upright and compact growth, showing a profusion of white flowers in June. Berries white, on noticeably red stems which hang on late in the fall Attractive to desirable birds. Each 50c.

CORNUS LUTEA (Yellow Branched Dogwood)-Green foliage; a shrub of medium size with bright yellow bark in the winter. Fine for contrasting with other shrubs in mass planting. Each 50c.

CORNUS SIBERICA (Red Osier)-Similar to the above but with bloodred branches in winter and early spring. Fruit bright blue and flowers white. This variety is used a great deal in mass planting for the color effect it gives during the winter and spring. Attractive to desirable birds. Each 50c.

CORNUS SERICA (Silky Dogwood)-Usually dwarf-growing with silky leaves and dense cymes of greenish white flowers in early summer, with purplish branches and light blue fruit during the winter. Very hardy and desirable shrub. Each 50c.

CORNUS SANGUINEA-Foliage dark green with purplish-red branches during winter and early spring. A strong grower and desirable for screen planting. Each 60c. 
Hardy Ornamental Shrubs,

\section{Continued}

CEPHALANTHUS OCCIDENTALIS (Button Bush)-Hardy ornamental shrub with handsome glossy foliage and very attractive flower balls appearing late in the summer. In flower after most other shrubs are out of bloom. Each $60 \mathrm{c}$.

CRETEAGUS CRUS-GALLI (Cockspur Thorne)-Native shrub or small tree with white blossoms and showy red fruit in the fall and early winter. Each 50c.

CYDONIA JAPONICA (Japan Quince)-Old-fashioned shrub with glossy leaves and scarlet flower in great profusion in early spring before the leaves come out and followed by small Quince-shaped fruit which are quite fragrant. Each $60 \mathrm{c}$

\section{Deutzias}

DEUTZIA GRACILIS (Dwarf Deutzia)-A dwarf, low-growing bush, never taller than 3 feet. Is covered very early in the spring with pure white bell-shaped flowers. Very desirable where a low-growing shrub is wanted. Each 50c.

DEUTZIA, PRIDE OF ROCHESTER-Extremely ornamental and graceful shrub, producing an abundance of double white flowers along the full length of the branches in June. Each $60 c$.

DIERVILLA TRIFIDA-A shrub closely allied to the Weigelias, but blooming after they have finished. Flowers a lemon-yellow in rather inconspicuous, flat, irregular clusters. A strong, hardy shrub and valuable as a late bloomer. Each 75c.

\section{Euonymous}

EUONYMOUS AMERICANA (Indian Wahoo)-Native shrub with greenish branches of upright growth, bearing small white flowers in early spring and full of showy fruit, of rose color with scarlet seed coat, which hang on during the winter. The bright color of the fruit gives it the name of strawberry bush. Called Wahoo by the Indians. Each $40 \mathrm{c}$

EUONYMOUS ALATUS (Japanese Euonymous)-Dwarf compact habit; wood very corky, which gives it the name of cork-barked Euonymous. Small delicate flowers in late spring, followed by very bright red berries in the fall. Foliage turns to a brilliant red in the fall. One of the finest shrubs for autum effect. Each 75c.

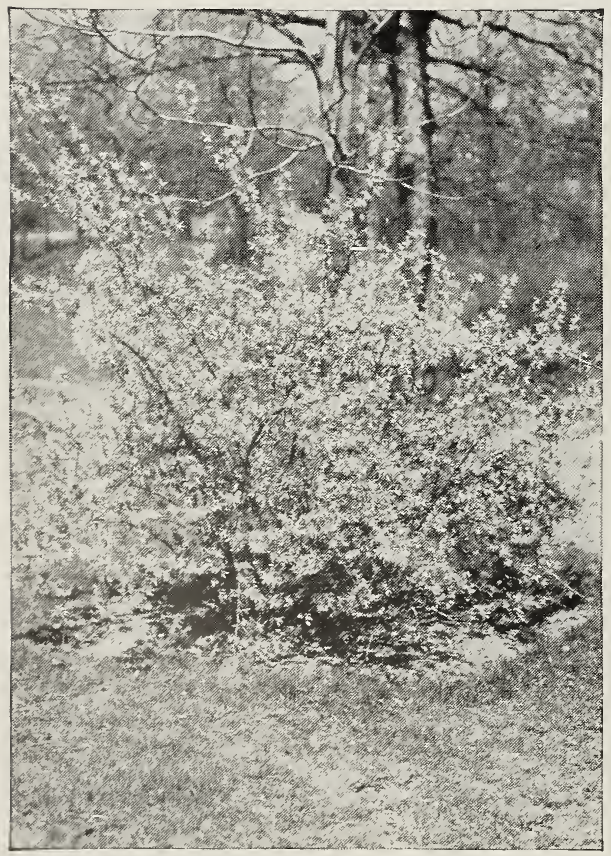

Forsythia Intermedia

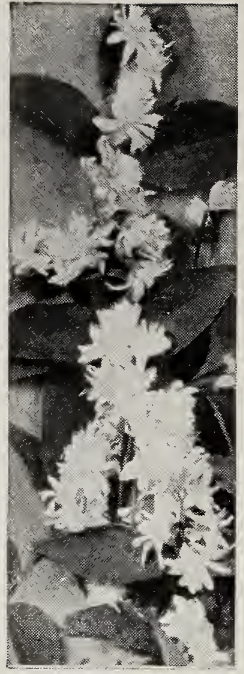

Remember we visit grounds, either private or public, and give suggestions for beautifying with shrubs and plants. Owing to our immense stock of ornamentals we are able to make very low prices on a quantity. Correspondence invited.

Deutzia Pride of Rochester
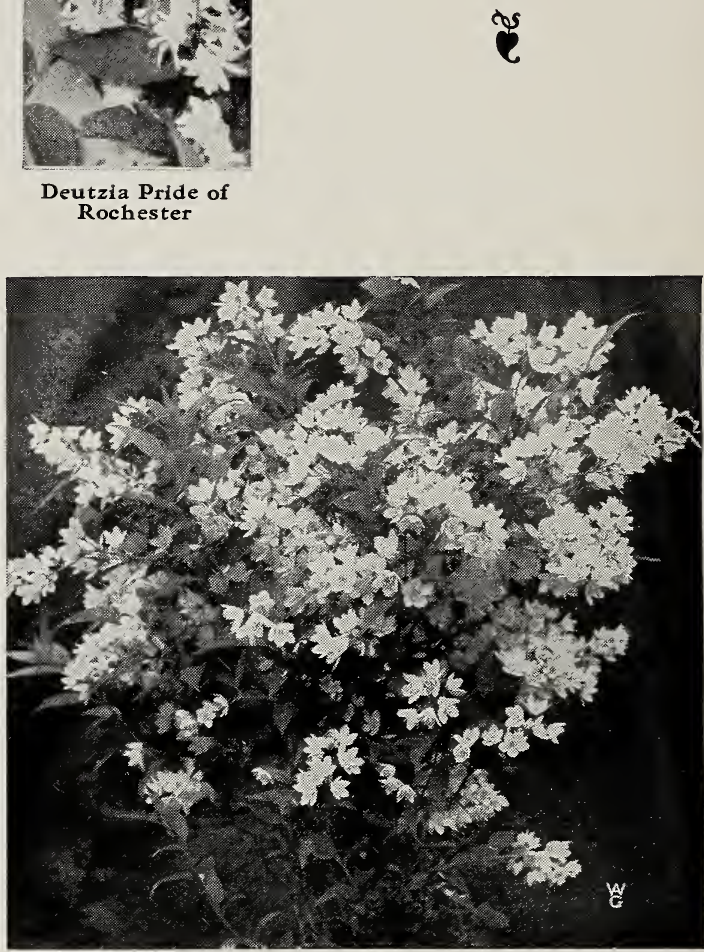

Deutzia Gracilis

ELEAGNUS ANGUSTIFOLIA (Russian Olive)-Rather large growing shrub with silvery foliage, about the color of the Dusty Miller. Fine for planting in contrast with other shrubs. Has fragrant yellow flowers in June, followed by yellow fruit. Each 50c.

\section{Forsythias}

FORSYTHIA INTERMEDIA (Golden Bell)-One of the most desirable for foundation planting or border, being very graceful in habit and adapting itself to almost any soil or situation. Flowers yellow and bellshaped, bloom along the entire length of the branches in early spring before the leaves appear. This is the earliest shrub we have to bloom in the spring. Each 50c.

FORSYTHIA SUSPENSA (Drooping Golden Bel1)-Drooping or trailing variety of the above. Fine for shrub borders or covering banks and terraces. Has dense dark-green foliage. Each 50c.

Do not confuse us with jobbers-who buy and sell. We grow our stock and know its merits when we catalog it. 


\section{Hardy Ornamental Shrubs, Continued}

\section{Hydrangeas}

HYDRANGEA ARBORESCENS (Hills of Snow)-Medium sized shrub of 4 to 5 feet. The flowers are in a large way similar to the old and familiar Snowball in appearance, conspicuously white and imposing, blooming throughout the season. They are excellent for solid low borders or foundation planting, does well in shade Each 75c.

HYDRANGEA PANICULATA GRANDIFLORA (Hardy Hydrangea)-A well known hardy shrub that blooms from August until late fall. The blooms are first white, then turn pink on the exposed side and finally a greenish-white in the late fall and hang on all winter. It produces the largest flower heads of any of the shrubs. Allowed to grow naturally, it assumes stately proportions. reaching a height of 7 or 8 feet, and during the hot months is covered with its pyramidal panicles, dronping gracefully of their own weight. Each $75 \mathrm{c}$.

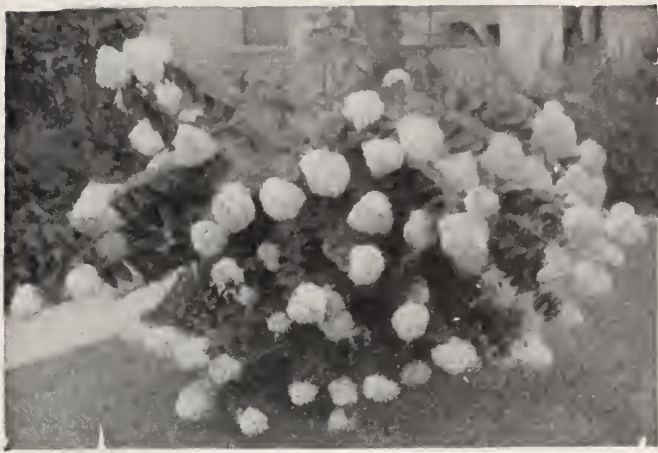

\section{Honeysuckles}

HONEYSUCKLE TARTARIAN-Tall, bushy shrub, with pink flowers in spring followed by red or orange colored berries. At tains a height of from 8 to 10 feet. Its dense foliage and rank growth makes it one of the best for screen planting. Each $40 c$.

HONEYSUCKLE MORROWI (Japanese Bush Honeysuckle)-Wide-spreading branches growing from 4 to 6 feet in height; color of foliage a blueish-green. Flowers white, changing to yellow; fruits bright red, attractive to desiratle birds. The branches drooping gracefully to the ground, making it suitable for foundation planting as well as front of shrubs. Each 60c.

HONEYSUCKLE RED TARTARIAN-Grows to height of 8 to 10 feet with upright, somewhat spreading branches and upright green foliage. The flowers are borne freely in May and June, are of a bright red color, followed by showy red berries, which ripen in mid-summer and cling to the bushes for several weeks. One of the best shrubs for northern latitudes as it stands severe winters. Each 50c.

PUSSY WILLOW (Salix Discolor) -A quick-growing shrub or small tree, blooming very early in the spring before the leaves come out. The fern-like catkins borne along the branches, makes it very attractive. Each $40 c$.

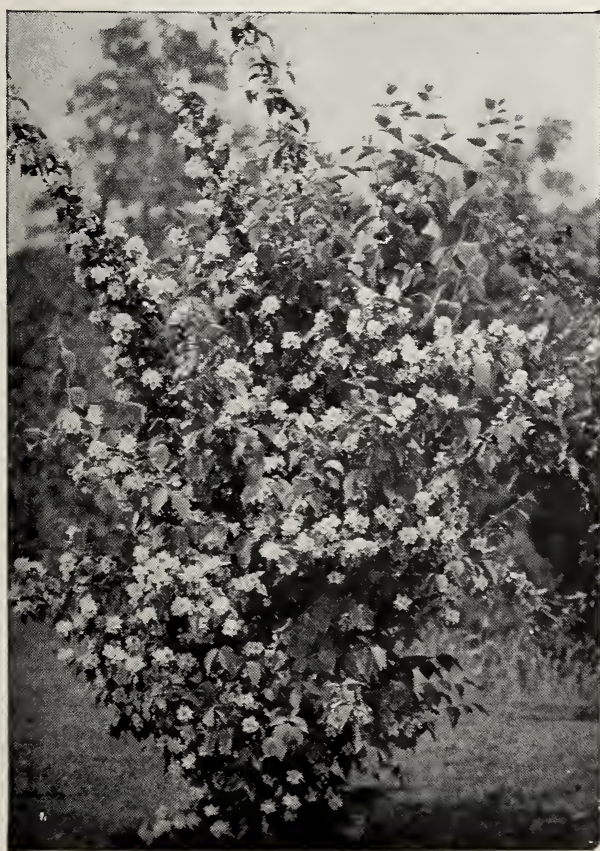

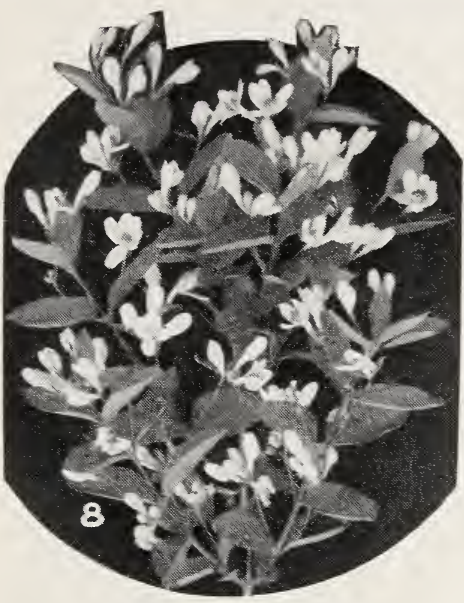

Bush Honeysuckle

\section{Kerrias}

KERRIA, WHITE Handsome shrub usually 4 to 5 feet high, native of Japan, with beautiful yellowishgreen, corrugated leaves and large single white flowers late in May and occasionally throughout the summer. Well adapted for foundation and in front of shrubbery plantings. Each $60 c$.

KERRIA, YELLOWSame as above, only the bloom is a double yellow and blooms all summer. A splendid new shrub. Each 75c.

\section{Philadelphus}

PHILADELPHUS CORONARIUS (Syringia or Mock Orange)-Oldfashioned shrub with vigorous, erect habit and highly scented white flowers. The breatk of Orange Blossoms-of such ent rancing fragranceintense from the multitude of bloom that it is a necessity to a garden, and works solendidly in all sorts of plantings. Each 50c.

PHILADELPHUS GRANDIFLORA-Similar to the above with more vigornus growth and larger flowers. The Syringias are valuable for grouping with other shrubs, forming large screens or hedges, which may not require pruning, and a!so fine for planting for lawn specimens. Each 50c.

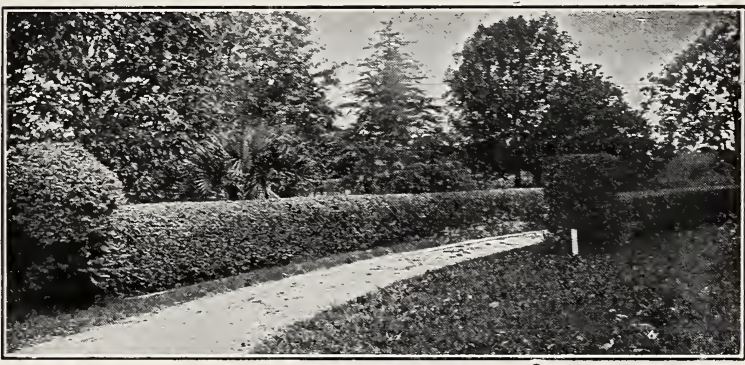

Amour River Prive

\section{Privet}

PRIVET, AMOUR RIVER-IVell known formal hedge plant for shearing, resembles the California Privet, but is much hardier and best for this latitude. The privets are not particular as to soil and they grow rapidly in open places or beneath the shade of trees. They are seldom attacked by insects, withstand shearing and can be kept at any height or clipped into artificial shape. Size, 18 to 24 inches $\$ 20.00$ per 100 : Size 2 to 3 feet $\$ 25.00$ per 100 .

REGAL'S PRIVET-A low-spreading form with gracefully drooping branches, adapted to much the same use as the Japanese Barberry. The dense growth and dark green, persistent leaves, make it a desirable shrub for foundation or border planting, growing in shade and other impossible places. Each 50c. 


\section{IIardy Ornamental Shrubs, Continued}

ROBINIA HISPIDA (Rose Acacia or Flowering Locust)-Medium size shrub with light green pinnate leaves and long, graceful clusters of pea-shaped rose-colored flowers in June and often throughout the summer. Often called Moss Locust. Each 75c.

\section{Rosa (Shrub Roses)}

The following group of Roses consists of hardy, vigorous varieties that require very lit the attention or pruning. Fine for the border or naturalistic groups, producing a profusion of single blooms, followed by a wealth of fright colored fruits that prolong their beauty well into the winter months. For garden varieties see page 26.

ROSA BLANDA (Meadow Rose) - Single pink flowers, erect habit, with slender reddish-purple branches, almost thornless. Especially adapted for mass planting. Red bark conspicuous in winter. Each 50c.

ROSA NITIDA (Dwarf Prickly Swamp Rose)-Low shrub with glossy foliage and single pink flowers, followed by bright colored fruits that hang on into the winter. A very hardy and desirable shrub. Each 60c.

ROSA RUGOSA (Japanese Wrinkled Rose)-A valuable, perfectly hardy Rose much used in landscape work, growing equally well in sun or shade. The heavy wood and shrubby formation adapting it to hedges and hardy borders or to mixed shrubbery groups. The foliage is lustrous, dark-oreen, usually corrugated and impervious to attacks of insect pests. Flowers borne in clusters of varying size and construction and are succeeded in winter by persistent fruits which are large and showy. Each 50c.

ROSA SETIGERA (I1linois Prairie Rose)-A native climbing rose found growing wild throughout Central lllinois. Large single flowers borne in clusters, color a bright rosy-pink. Useful for massing in picturesque hillside brambles, as borders to wildwood drives, as filling for dea corners, and with equal harmony, as a congenial mixer with shrubs and in single specimens. The foliage is extremely free from any defects and of a rich dark green. Each 50c.

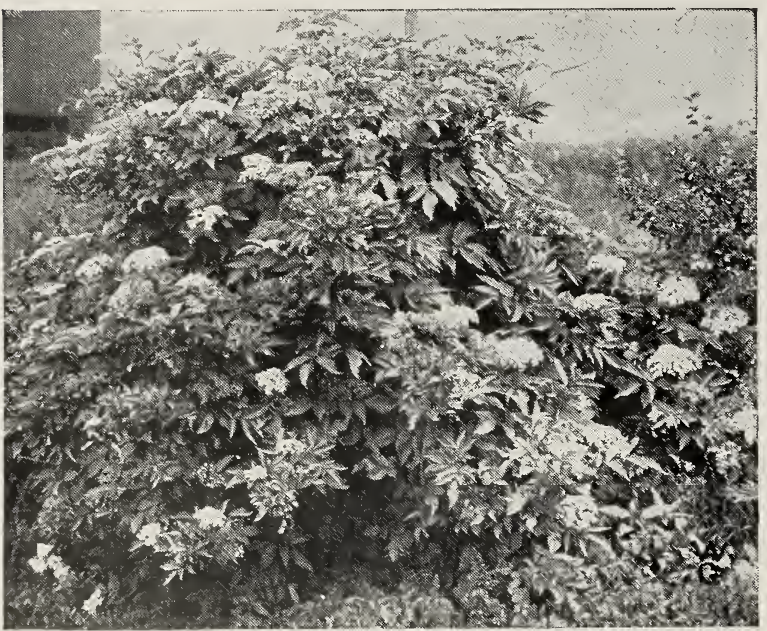

Sambucus Aurea (Golden-Elder)

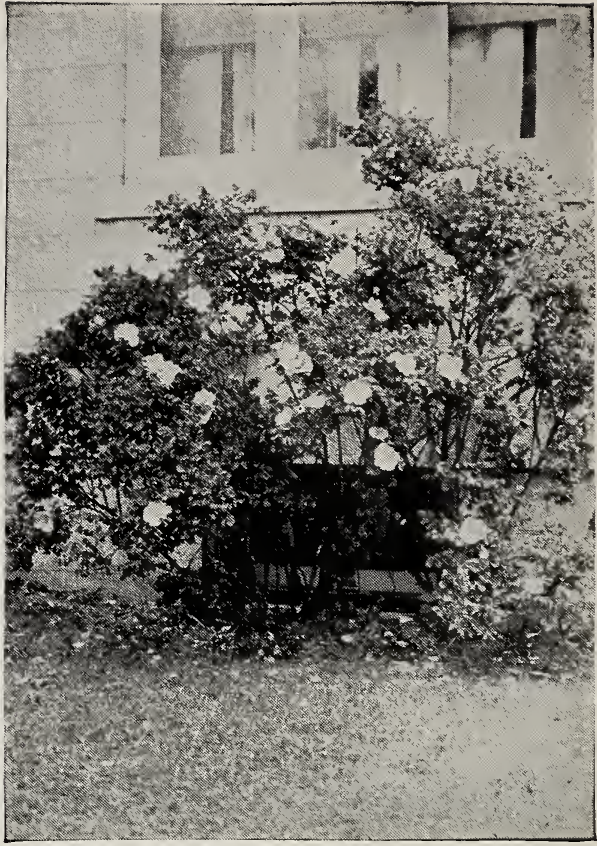

Rosa Rugosa

\section{Rhus}

RHUS GLABRA (Smooth Sumac)-A large native shrub with branches taking the shape of stag horns. A highly ornamental shrub of wonderful foliage and brilliant fall colorings. Each 50c.

RHUS TYPHINA LACINIATA (Cut-Leaved Sumac)Similar in growth to the preceding, but having finely cut leaves resembling fern leaves, which turn to brilliant
orange and scarlet in the fall. Very popular for screen planting or massing with other shrubs. Each $60 \mathrm{c}$.

\section{Sambucus}

SAMBUCUS AUREA (Golden Elder)-Its golden-yellow leaves contrast beautifully with other shrubs. Flowers white in flat-topped cymes. Grows naturally 8 to 10 feet, but can be pruned into a neat, compact little bush. Each 40c.

SAMBUCUS LACINIATA (Cut-Leaved E1der)-Similar to the common Wild Elder, but with finely cut foliage, making a very desirable, handsome shrub. Produces handsome cymes of delicate, white, fragrant flowers in June and July, followed by large clusters of black fruit. Splendid for massing with other shrubs. Each $60 \mathrm{c}$

SAMBUCUS PUBENS (Red-Berried Elder)-Rather compact shrub growing from 5 to 7 feet high. Native of Wisconsin. Flowers white in flat-topped clusters, followed by very showy red berries which hang on unti late. Each 50c.
View of private lawn at home of Attorney T. J. Welch of Kewanee, Illinois. This landscape design and all plants
were furnished by the were furnished by the
Home Nursery. Note the beauty of the Engelman's Ivy on the stucco walls, and the large clump of Cut - Leaved Sumac in the center of foreground.

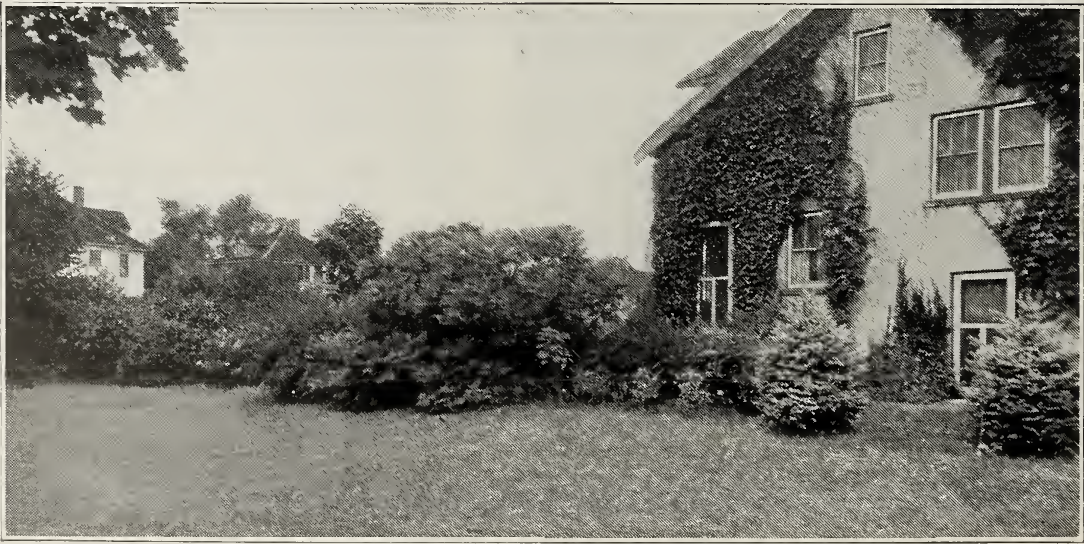




\section{Hardy Ornamental Shrubs, Continued}

\section{Spirea (Bridal Wreath)}

Large family of shrnbs of refined, gracef nl habits, suitable to plant in almost 3ur situation. The great abundance of blossoms and variation of color and season of bloom, make them very popular and as videly planted as any group of shrubs under cultivation. Varieties as follows:

SPIREA ANTHONY WATERER - Low-growing type of very compact dense habit, with flat-topped clusters of rose-colored flowers throughout the season. Fine for planting singly where a low, formal shrub is wanted and also well adapted for planting in front of larger shrubs or for foundation planting. Each 50c.

SPIREA ARGUTA-One of the finest of the early spring blooming shrubs. of light slender growth of somewhat drooping habit; foliage deep green; flowers, minute pire white. Medium size shrub. Each 75c.

SPIREA COLOSA ALBA-Very low-growing dense shrub seldom over one foot high, corered during the entire season with flat-topped clusters of greenish white flowers. Fine for edges of beds or for shrubbery border. Each 50c.

SPIREA COLOSA RUBRA-Very compact shrubs from 3 to 4 feet high. similar in habit to the preceding, with deep crimson, flat-topped clusters of flowers blooming occasionally throughout the season. A very graceful shrub that fits in anywhere. Each 50c.

SPIREA BILLARDI-L'pright-growing, from 3 to 4 feet high, with long dense spikes of pink flowers in late spring and occasionally throughout the summer. Flowers fine for bouquets. Each 50c.

SPIREA FROEBELI (Frobel's Spirea)-Compact shrub of medium height, producing numerous flat-topped clusters of dark pink flowers in late spring and summer. Splendid foliage, especially during the late autumn. Each 50c.

SPIREA DOUGLASI-One of the best of the summer-flowering Spireas. Medium sized with immense terminal spikes of deep rose-colored flowcrs. A very desirable variety suitable for planting singly or with other shrubs. Each 60c.

SPIREA OPULIFOLIA (Ninebark)-Tall, vigorous shrub, attaining a height of from 8 to 10 feet and covered with flat clusters of white flowers in June, which later turn to pink, followed by attractive seed pods. Very ornamental for large screen planting or for lawn specimens. Each 50c.

SPIREA OPULIFOLIA AUREA (Golden Ninebark)-Similar to the preceding, except it has bright golden foliage, especially early in the summer. Each 50c.

SPIREA SALICIFOLIA (Willow-Leaved Spirea)-Erect growing shrub with narrow leaves and panic!es of white flowers from Jine until September. Fine for massing with other shrubs. Each 40c.

SPIREA PRUNIFOLIA (Plum-Leaved Spirea)-Shrub of rather stiff. dense growth, with shiny foliage turning to bright autumn tints in the fall. Flowers small double-white and very showy. Each 40c.

SPIREA THUNBERGI (Snow Garland)-Low, graceful shrub of fine texture in branch and leaf. Pure white flowers are borne in great profusion before the leaves appear, giving the plant the appearance of being covered with snow. Each 60c.

SPIREA SORBIFOLIA (Mountain Ash-Leaved)-Hardy shrub from Northern Asia, growing from 3 to 5 feet. Foliage similar to the Mountain Ash; bright green, and makes striking contrast with other shrubs. Fine for beds or foundation planting. Flowers in large white panicles during the summer. Each 60c.

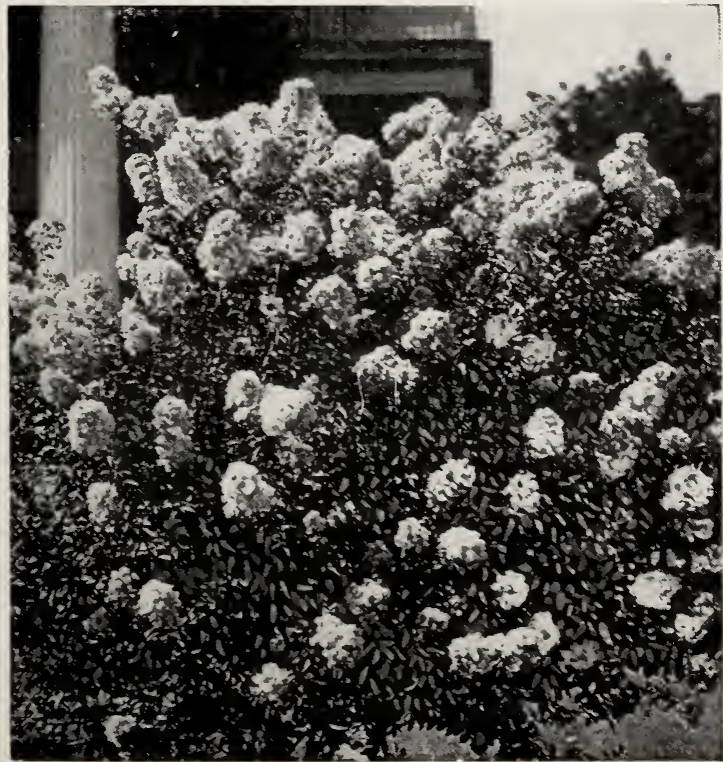

SNOWBERRY-Medium-sized shrub with bluish-green foliage and rose-colored flowers in June and July, followed by large clusters of white, waxy fruits that hang on far into the winter. A very graceful shrub that fits in most anywhere. Grows equally well in shade. Each 50c.

CORALBERRY - Low, almost trailing, graceful shrub with coral-colored berries that hang on during the winter and are very showy. Its graceful habit and fine texture of foliage and twigs make it one of the best for foundation planting and borders. It grows naturally in open woods and along hedgerows. Native of Missouri, called Missouri Currant. Each $40 \mathrm{c}$

\section{Syringas (Lilacs)}

SYRINGA VULGARIS (Common Purple Lilac)-Large old-fashioned shrub with bluish-purple flowers, very sweetscented. The most popular and earliest to bloom of all the Lilacs. Each 50c.

SYRINGIA ROTHOMAGENSIS (Hungarian or Rouen Lilac)-Shrub attaining from 10 to 12 feet in height, with rather slender arching branches, with large panicles of reddish-purple blossoms. Hungarian variety originating at Rouen, France. Fine for single specimens or for heavy. borders. Each 60c.

TAMARIX PENTANDRA-Shrub or small tree witl redish-purple branches and blueish-green feathery foliage. Flowers in large pink panicles in August and September.
Owing to its fine feathery foliage it has the appearance of an evergreen during the summer. Can be sheared in any shape. Each 60c.

You will do your friends a servSyringa Vulgaris ice by telling them about our values. 


\section{Hardy Ornamental Shrubs, Continued}

\section{Virburnums}

\section{(The Arrow Woods or Snowball)}

In this group are included the Snowballs, which give in spring the same showy effects that Hydrangeas produce in the fall Viburnums are invaluable in shrubbery borders, desirable as specimens and generally useful. Most varieties grow satisfactorily in partially shaded places although they will, of course, flower better in sunny locations. Beautiful autumn foliage is displayed by some varieties. Others are valued for their ornamental berries.

VIBURNUM DENTATUM (Arrow Wood)--Upright, growing to 6 feet in height, with light green dentate leaves. Flowers greenish-white; fruits black. A fine shrub for massing or foliage effect. Each 60c.

VIBURNUM LANTANA (Wayfaring Tree)-A large, robust shrub to 10 feet in height with fuzzy foliage, light green above and silvery beneath Large clusters of white flowers followed by red fruits. Retains its foliage late in the fall. Each 60c.

VIRBURNUM OPULUS (Highbush Cranberry)-Tall and upright, with good foliage and especially decorative red fruits in large clusters which resemble Cranberries, and hang on until freezing weather. Fine for large screen planting. Each 60c.

VIBURNUM OPULUS STERILUS (Common Snowbal1)-Oldfashioned shrub that grows anywhere and blooms well. Characterized by its large clusters of white flowers, resembling snowballs. Always in bloom on Decoration Day. Each 50c.

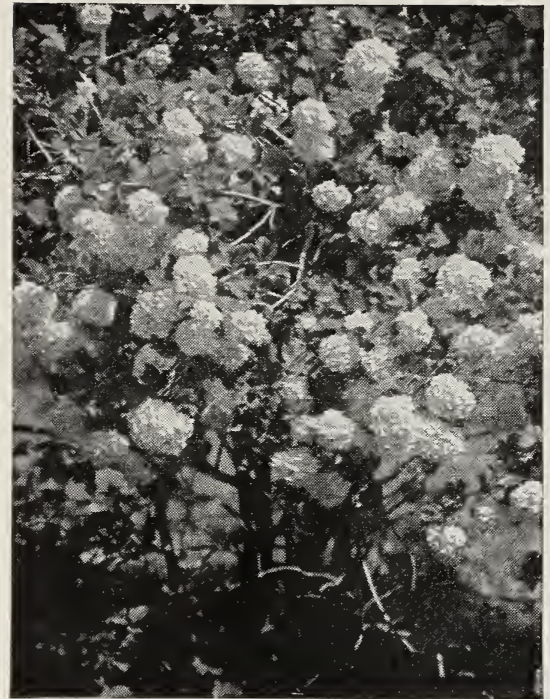

Viburnum (Snowball)

\section{Come}

and

Visit

Us

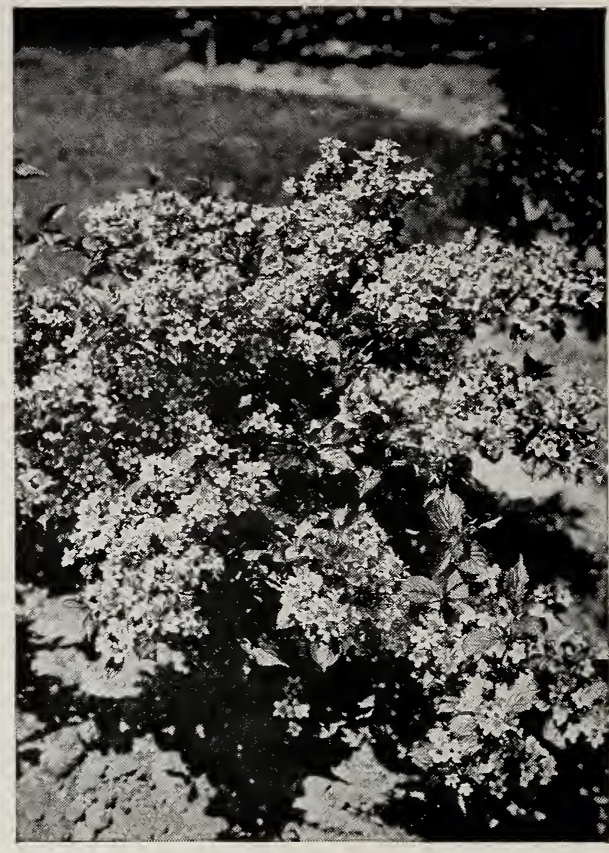

Weigela Rosea

\section{Weigelias}

WEIGELA ROSEA (Rose-Colored Weigela) - Very free-flowering shrub, growing 5 to 7 feet. Flowers are produced in so great profusion as to almost hide the foliage. A well known shrub, fine for massing or for single specimen. Each 50c.

WEIGELA EVA RATHKE (Hybrid Weigela)-Dwarf but erect shrub with deep carmine-red flowers; flowering continuously throughout the summer. The finest of the Weigelas. Each $\mathbf{7 5 c}$

\section{Shrubs Adapted to Shady Places}

It is quite of ten that plantings are required in the shade of the house or unde large trees. The following shrubs will grow in shade and give good results. In places that have been shaded for a considerable time the soil often becomes sour and few varieties of shrubs or plants will thrive in it without the application of lime to counteract the acidity:

Japanese Barberry; Sumac, in variety; Flowering Currant; Forsythia; Choke Cherry: Coralberry; Viburnums; Red-barked Dogwood: Hydrangea Arborescens; Deutzia, in variety; Privet; Snowberry.

\section{Plants Suitable for Hedging}

The following varieties of trees and shrubs are recommended for planting for ornamental hedges. Plants should be set from 8 to 12 inches apart, according to the height hedge wanted. And if it is desirable to have the hedge very thick at the bottom they should be set in double rows.

Prepare the ground for a hedge by spading full 10 inches deep and a space 3 feet wide, the length required, and set the plants in the middle of the spading and keep well cultivated the first vear. All plants except evergreens should be cut back to within three or four inches of the ground after planting, to make them branch low. The following kinds may be sheared to any desired form

Japanese Barberry-12 to 18 inches, Spirea Van Houtei-2 to 3 feet,

Amour River Privet-18 to 24 inches, Amour River Privet-2 to 3 feet,

American Arbor Vitae 12 to 18 in. American Arbor Vitae-18 to 24 in. Norway Spruce-18 to 24 in.

Per 100 $\$ 20.00$ 25.00 20.00 25.00

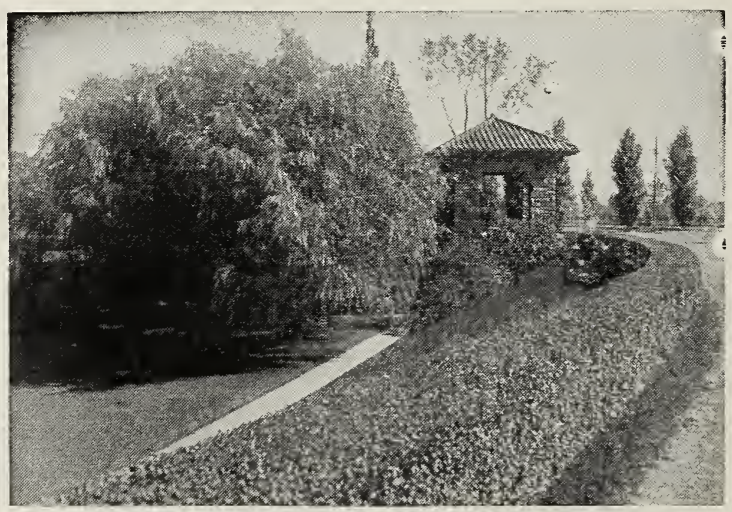

Privet Hedge with a Weeping Willow in background 


\section{Hardy Vines and Creepers}

In the beautifying of grounds the climbing slirubs are indespensable. They will grow where other ornamentals find no room. For home cmbellishments there is nothing that adds more grace to the exterior of a house than wellplaced and appropriate vines. The enchanting pergola, placed and and cover, gives that artistic effect that no other treatment can produce. Climbing vines add comfort, perfume and fowers.

Vines should have deep, rich soil, and without which these charming shrubs will be both disappointing and commonplace. Generally vines about the house get set in a mixture of clay, brickbats, cinders and building refuse, and the owner finally decides that vines are not much good; while if the ground had been prepared by filling in with good rich soil before planting, and mulched heavily with wellrotted manure in the fall, the results would be most satisfactory.

AMPELOPSIS VEITCHI (Boston Ivy) - The most popular climbing plant for covering brick, stone or wooden walls, trees, etc. When it becomes established it is of very rapid growth and clings to the smoothest surface, covering closely with overlapping foliage, giving the appearance of shingles. The color is a fresh deep green in the summer, changing to the brightest shades of crimson and yellow in the fall. Not absolutely hardy in the north. Each 75c.

AMPELOPSIS ENGLEMANI (Engleman's Ivy)-A smallleaved variety of the American Ivy or Virginia Creeper. Extremely hardy and strong growing and easy to get started, will cling closely to any kind of a wall without any support; dense, light green foliage in summer, changing to a brilliant crimson in the autumn. The very best and hardiest for this latitude. Each 40c.

CLEMATIS JACKMANI-Hardy vine with very large purple flow-
ers. There is no climbing plant that equals it in attractiveness or beauty. They like a rich, moist situation and not too sunny a location. The crowns should be planted about 3 inches deep. Each \$1.00.

CLEMATIS PANICULATA (VITgin's Bower)-..A strong luxuriant grower with light green foliage that is handsome in itself. Small white fragrant flowers in feathery panicles, blooming late in the season. Very popular, CELASTRUS SCANDENS (American Bitter-Sweet) - Well
known native climber, handsome known native climber, handsome
glossy foliage and large clusters

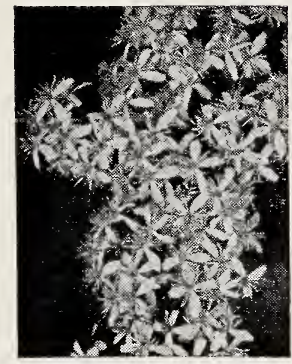

Clematis of beautiful orange crimson fruits retained all winter. Its graceul sprays of berries make charming winter home decorations. Fine for covering old stumps or rough fences. Each 50c.

CEIASTRUS ORBICULATUS (Japanese Bitter-Sweet)Hardy vine of much more vigorous growth than the preceding. Very prof use in its orange yellow fruits that persist all winter. Each $75 c$.

JAPANESE SPURGE (Pachysandra Terminalis)-A hardy evergreen ground cover with attractive dark green leaves, valuable for planting in shady places where grass will not grow. When once established it becomes a veritable mat, completely covering the ground. Also suitable for grave covers. Each 35c.

LONICERA HALLIANA (Japan

Honeysuck1e)-Strong grower, holds

its dark-green foliage until early winter; almost evergreen. Flowers white, changing to yellow; very fragrant. Unanging to yellow; very fragrant. cover. Each 50c.

I.ONICERA SEMPERVIRENS (Trumpet Honeysuckle) - Very old-fashioned vine with scarlet trumpetshaped flowers borne in great prof usion. Very attractive to Humming Birds during the summer. Each 50c.

LONICERA PROLIFERA - Wild Honeysuckle found in our woods of bushy half-climbing habit, 5 to 7 feet tall. Leaves very thick, glaucous or light blue, the upper ones united into a disk, the stem passing through the center. Flowers in May, pale yellow, followed by a very showy, compact clusters of red berry-like fruits, that hang on until winter. Its blue color

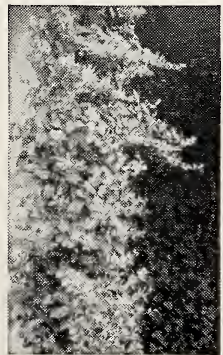

Honeysuckle

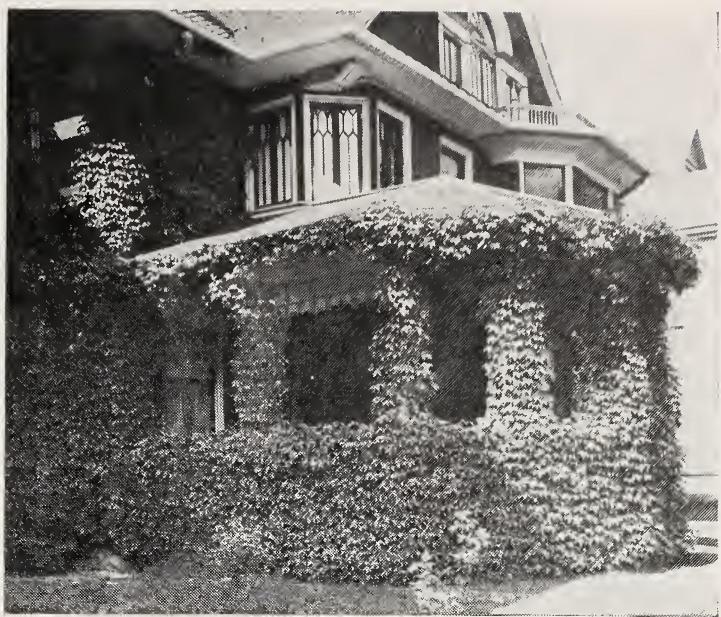

Ampelopsis Veitchi (Boston Ivy)

KUDZU VINE-A perennial vine from Japan with a large tuberous root. When well established, will make a growth of 40 to 50 feet in a season. Dies down to the ground each season. Flowers rosy purple, pea-shaped. Each \$1.00.

LICIUM VULGARE (Matrimony Vine)-Very showy vine with dark green foliage, small light blue flowers and coral-red berries borne in great prof usion. Each 40c.

VINCA MINOR (Periwinkle or Myrtle) - Hardy old-fashioned evergreen creeper well adapted for ground cover and rockeries. Leaves dark green and glossy; flowers blue. Fine for grave cover. Each 25c; per $10 \$ 2.00$.

FERNS (Hardy Woods Ferns). With few exceptions, Ferns do best in shady or semi-shady location in rich, well-drained soil where they can be supplied with water during dry weather. For naturalizing in woodland they are fine subjects planted with Foxglove, Funkias and Columbines. They are of extremely easy culture. Strong Clumps Each, 35c.

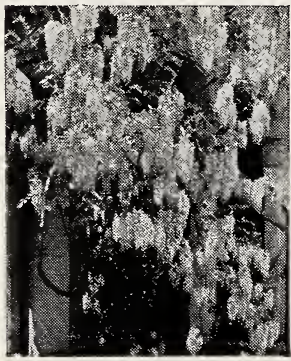

WISTERIA, PURPLE-One of the best hardy climbers producing dense drooping clusters of pea-shaped flowers in May and occasionally during the fall. Color violet blue, richly perfumed. One of the handsomest for pergolas, trellises and for pergolas, trellis

WISTERIA, WHITE-Same as the above only white flowers. These both are Chinese Wisteria and frafted plants and not to be compared with the

Wisteria

Plant Perennials in the flower bed where you have been using Annuals. Each year you have to replace the Annuals, whereas the Perennials come up season after season with very little work or expense. other shrubs. Each 75c.

DUTCHMAN'S PIPE VINE (Aristolochia Sipho)-A vigorous and rapid-growing climber, bearing singular, brownish-colored flowers, resembling in shape a pipe. Its flowers, however, a re of little value compared to its bright green leaves, which are of very large size and retain their color from early spring to late fall; perfectly hardy. Each $\$ \mathbf{1 . 2 5}$. 


\section{Hardy Perennials}

Hardy perennials appeal most especially to people that haven't the time to bother with plants that have to be reset every spring. One can have just as gorgeous displays of flowers by the use of hardy plants as with annuals, and they will live and increase in beauty each year. There are gardens where clumps of some of the old favorites have outlived three generations of owners.

Many kinds are up and in bloom before it is time to think about setting out annuals, and with a small border planting there is no time during the entire season but what one will find a wealth of bloom from some ore or more kinds of these most popular plants.

A garden of hardy perennials is a most important adjunct to the home, and the showy Peonies, Irises, Phlox, Hollyhocks, and the like, add a charm that can be had in no other way.

All strong field-grown plants, and will bloom the first season.

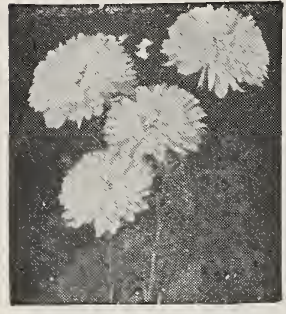

Chrysanthemums

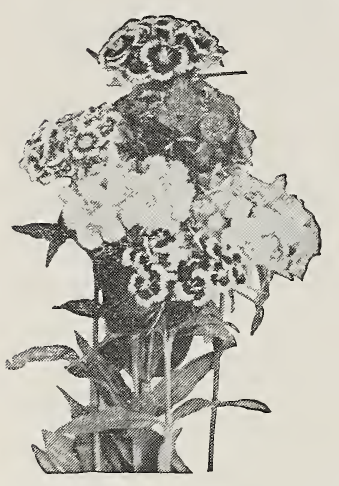

Sweet William

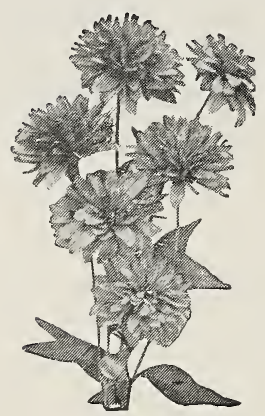

Rudbeckia

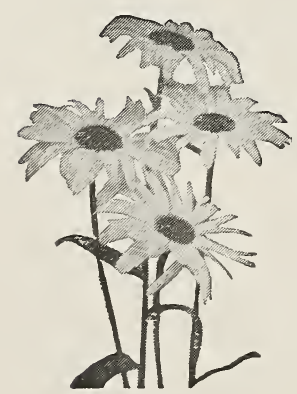

Shasta Daisies
ANCHUSA ITALICA-A very hardy and easily grown perennial. Flowers a rich genetian blue. Grows from 3 to 5 feet high. Flowers throughout the season. Each 35c.

ALTHEA ROSEA (Hollyhocks) - This stately old plant is truly "king" of the garden. Their colossal spikes of bloom, 5 to 7 feet high, produce bold and showy effects which cannot be secured with any other plant. Very effective a mong shrubbery and herbaceous border and along fences and boundaries. We offer them in separate colors, viz.: Crimson, White, Yellow, Maroon and Pink. Each 30c.

AQUILEGIA CAERULEA (Rocky Mountain Columbine)-One of the most beautiful of the Columbines, with very graceful, long-spurred the most beautiful of the Columbines, with very graceful, long-spurred bloom. Sepels deep blue and petals white. The foliage is good all
summer. Blooms during May and June. We obtained our seed direct from the mountains of Colorado and you may depend upon getting the true kind. Each 50c.

BLEEDING HEART-An old-fashioned favorite. Its arching stems bear drooping, heart-shaped flowers of white and rose red. It is perfectly at home in any part of the hardy border and especially valuable for planting in shade. Each 50c. (See inside front cover for full color illustration.)

BOLTONIA ASTEROIDES-Strong-growing, makes large bushy clumps 4 to 5 feet high; covered with aster-like flowers late in the fall, remaining in bloom a long time. Suitable for background for other perennials. in bloom

CHRYSANTHEMUM-The hardy "Mums" bloom profusely in October after everything else in the garden has been killed by frost. They are excellent for cut-flowers and bouquets. There are but few kinds that are really hardy in this latitude. We offer the very best in the following named colors, viz.: Yellow, Pink and White. Each 35c.

COREOPSIS LANCEOLATA -Flowers are a rich golden-yellow, borne in great profusion nearly the entire summer. This is one of the most in great profusion nearly the entire summer. This is one of the most amount of cut-flowers, besides taking an important place among the amount of cut-flowers, besides taking an important place
hardy border plants of 18 to 24 inches high. Each 35c.

DELPHINIUMS (Larkspur) - The hardy Larkspurs are easily among the finest of all our perennial plants. The prevailing colors are rich, clear shades of blue. The taller kinds furnish long spikes of bloom that are strikingly decorative and last a long time as cut-flowers. The plants have a long season of bloom which can be greatly prolonged by keeping the seed stalks cut out and supplying plenty of water. The dark, handsome foliage is neat and attractive throughout the whole season. The some foliage is neat and attractive throughout the whole season. The plants are perfectly hardy. Blooms from June until frost. Four kinds:
Light Blue, Dark Blue, Dwarf Royal Purple and Hybred. Each, 35c. Light Blue, Dark Blue, Dwarf Royal Purple and Hybred. Each, 35c.
DIANTHUS BARBATUS (Sweet William)-Old-fashioned garden pinks comes in various colors and blooms continuously all summer. Suitable for borders and edges. Each 35 c.

DIANTHUS PLUMARIUS (Grass Pinks) - This very desirable sweet scented, low-growing early blooming and free-flowering Hardy Pink is unequaled for the borders of beds or drives, or for old-fashioned gardens. Blooms throughout the season. Each 40c.

DIGITALIS (Foxglove)-Flowers in immense spikes during July and August and if seed stalks are cut away will bloom until frost. They are fine for the mixed border. The large, rough, dark-green foliage is attractive. Each, 35c.

FUNKIA SUBCORDATA (White Day Lily)-Large full clumps of handsome foliage, with large, fragrant, pure white flowers. Blooms in August. Both the foliage and flowers are conspicuous, so even when not in bloom, the plants are attractive. Suitable for most any part of the garden. Each 50c.

FUNKIA LANCEOLATA (Blue Day Lily) - Lilac-colored flowers, valuable for its late blooming. Not as vigorous as the preceding. Each 35c.

GAILLARDIA (BlanketFlower)-Daisy-shaped flowerswith orange-tipped AILLARDIA(Blanket Flower)-Daisy-shaped flowerswithorange-tipped until frost. Their long flowering period, long stems and bright colors make it one of the most valuable of the perennials, being easily grown in beds or borders in any ordinary soil. Each $25 \mathrm{c}$.

GYPSOPHYLA (Baby's Breath) -A beautiful old-fashioned plant, possessing a grace not found in any other perennial. When in bloom during July and August it forms a symmetrical mass 2 to 3 feet in height and as much through, of minute pure white flowers, forming a beautiful gauze-like appearance. When cut it is exquisite in combination with other flowers. Each, 40c.

LEMON LILY (Hemerocallis)-Magnificent hardy plant and undoubtedly among the finest for ordinary garden culture, as they will doubtedly among the finest for ordinary garden culture, as they will
grow anywhere in either partial shade or full sin. The lemon-colored grow anywhere in either partial shade or full s11n. The lemon-colored
flowers are produced in clusters of 6 to a dozen blooms, opening in siccession and are very useful when cut for indoor decoration. Good for borders, shrubberies, wild garden or naturalizing in grass. Each 30c. POPPY ORIENTALE-For gorgeous coloring the Orinental Poppy has few rivals among hardy plants. Immense scarlet flowers that contrast vividly with the green of shrubbery or Evergreen borders during June and July. Each 50c.

LILY_OF-THE-VALLEY-Will thrive and throw up its beautiful, L modest, fragrant white bells in any kind of soil. It will make a carpet in those shady and cold spaces otherwise lost to orna mentation around in those shady and cold spaces otherwise lost to ornamentation around more ambitious plants. The bloom occurs in late spring and early summer. Strong clumps, each 25c.

LILIUM CANDIDUM (Madonna Lily)-Considered to be the Lily of the Bible. Bloom pure white, 3 to 4 inches long and as wide; delicately fragrant. Late June and July. Of easy culture in most any soil. Should be planted in the fall. Each 50c.

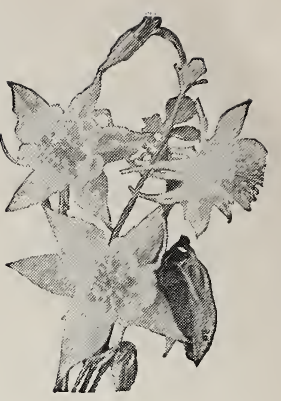

Aquilegia

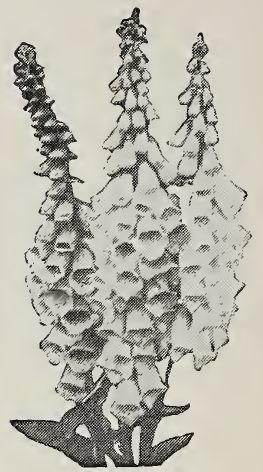

Digitalis

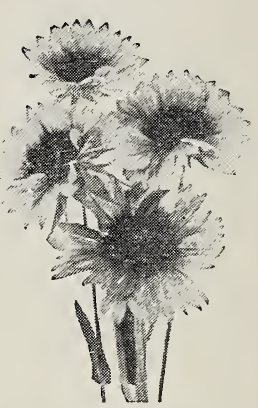

Gaillardia

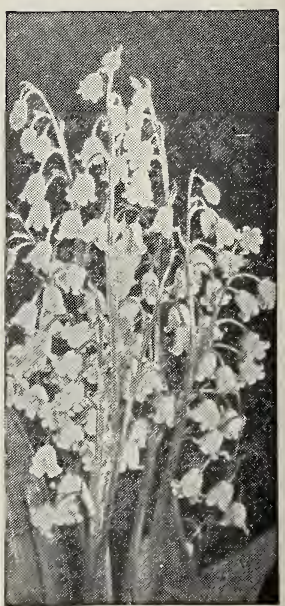

Lily-of-the-Valley 


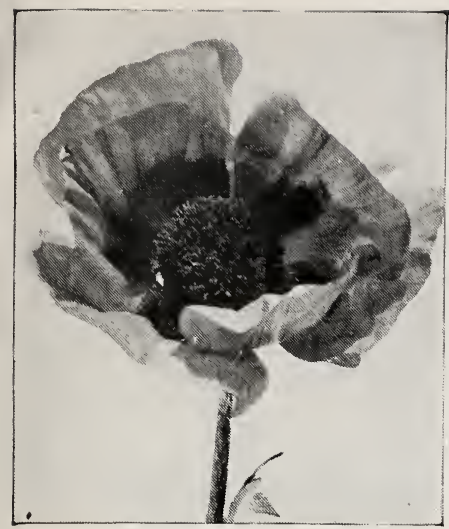

Oriental Poppy

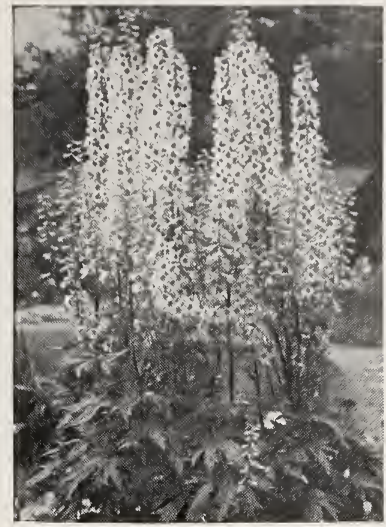

Delphinium

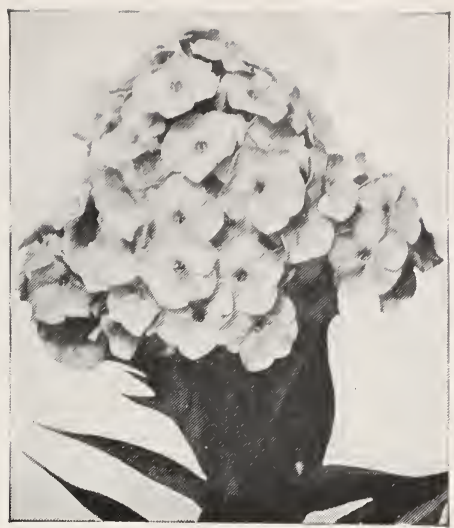

Phlox

\section{Hardy Perennials, Continued}

MYOSOTIS (Forget-Me-Not)-Few flowers are more admired than the FogetMe-Nots which bloom so profusely from May until September. The tiny blue flowers have a very appealing charm. The dwarf plants spread rapidly, carpeting the ground. Makes excellent edgings for beds or borders of perennial plants. Each 35c.

IRIS, or FLEUR de LIS (German Iris) - It is hardly necessary to describe this well known hardy perennial which is sometimes called Hardy Orchids because of the richness and beauty of the flowers. They vary in height from 2 to 3 feet, blossoming in June in exquisite shades of purple, lavender, blue, yellow and white. Each 25c.

IRIS KAEMPFERI (Japanese Iris)-The flowers are generally rather flat and wide, often measuring 9 to 10 inches across, appearing in great profusion in June and July after the German Iris are through. Each 50c.

IRIS SIBERICA (Siberian Iris) - A variety distinguished by its tall, grass-like foliage and clustered flowers of a royal purple on numerous slender stems. They reach a height from 2 to 3 feet and bloom from May to June. Each 35 c

HARDY CARNATIONS-The Carnation has long been prized as a hardy border l plant. Free-flowering and easily grown either in beds, borders or pots. It is one of the most valuable and beautiful of our summer flowers and a favorite with everyone. Blooms throughout the season. Should have a slight protection during the winter. Each $40 \mathrm{c}$

SEDUM SPECTABILIS (Live Forever)-Of upright growth, 12 to 15 inches high. Foliage round, thick and rubbery, crowned with massive flat cymes of dark crimson flowers. Will grow anywhere. Each 50c.

PHLOX PANICULATA (Hardy Phlox) - This is one of the most useful flowers for summer decorations, the colors varying from pure white to deep crimson. They are not at all particular as to soil and are extremely hardy. They can be used to advantage in the hardy border, in large groups on the lawn or planted in front of shrubbery where by judicious pinching back and removing faded flowers, a constant succession of bloom may be had until frost.

\section{VARIETIES}

Champs Elysee-Bright rosa-magenta. 2 feet high. Each 30c.

Eclaireur-Brilliant rosa-magenta. Each 30 c.

Mrs. Jenkins-P11re white, medium height. Each 25c.

R. P. Struthers-Rosy carmine with claret eye. Each $30 \mathrm{c}$

Rheinlander-Salmon-pink with distinct lye. Each 30c.

Rhynstrom-Beautiful rosy-pink, very free-flowering. Each 35c.

PYRETHRUM ROSEUM (Painted Daisy)-Beautiful plants with feathery foliage and blooms like painted daisies, coming in June. Very hardy and de sirable. Each 40c.

RUDBECKIA (Golden Glow) - Golden-yellow Dahlia-like flowers borne on tall swaying stems, blooms summer and fall. Very decorative for shrubberies or sides of drives. Each $30 \mathrm{c}$

Paeonias Paeonias, next to the Roses are certainly Peonias the most popular of the June flowers. They are well adapted for massing in beds and particularly adapted for planting in groups throughout the perennial or shrubbery border. The great flowers are perfectly formed and some are as fragrant and delicately colored as the Rose. They are perfectly hardy and increase in beauty and size from year to year.

\section{VARIETIES}

RUBRA OFFICINALIS-The oldfashioned early red Paeonia cultivated ever since the time of Pliny, and is still a favorite. Very large dark-red blooms in May. Each 75 c.

$75 c$

FESTIVA MAXIMA-Fxtremely large, pure white variety, fragrant and showy. The most popular white kind. Each 75c.

FELIX CROUSE-A rich, even, dazzling ruby-red. Strong grower. Finest variety for use as cut flowers. Each $\$ 1.00$

MIXED KINDS-We have a quantity of varieties in different color from pink to various light shades which we offer in strong unnamed cliımps at 50c each.

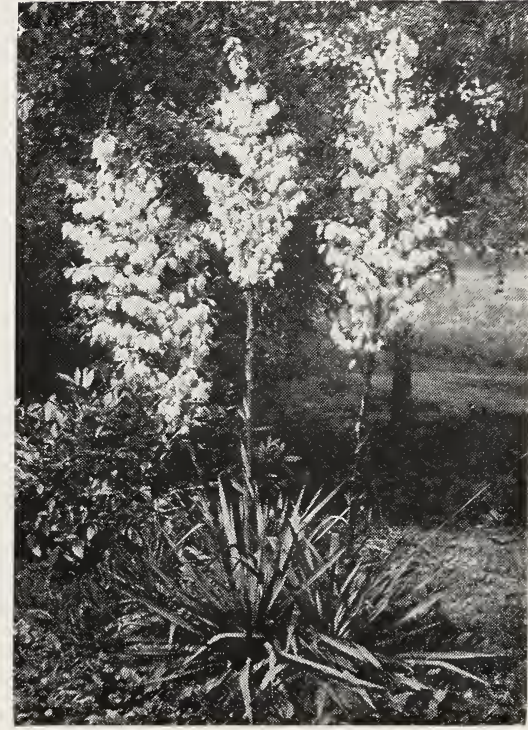

Yucea

SHASTY DAISY (Burbank's) - A hybred Chrysanthemum, very free-flowering with large and showy Daisy-like flowers, white with yellow centers. Blooms 4 to 6 inches across, extremely productive of bloom and splendid for cut-flowers. Each $35 \mathrm{c}$

TRITOMA PFITZERI (Flame Flower or Torch Lily)-A beautiful late flowering perennial having handsome reed-like foliage. Sends up stiff stems of orange-scarlet flowers from August until the ground freezes in the fall. Very showy and fine for borders and in front of shrubbery. Each 25c.

YUCCA FILAMENTOSA (Bear Grass)-Tle broad sword-like foliage is evergreen. Sends up tali stalks laden with creamy-white bell-shaped flowers during midsummer. Very desirable for herbaceous borders. Very hardy in either extremes of cold or heat. Each $40 \mathrm{c}$.

NOTE-For large assortment of the above perennials, write for special prices. We furnish"plans for perennial border free to our customers.

\section{Laun Grass Seed}

By using our specially prepared lawn grass seed mixture, a deep green, velvety sward can be produced in from four to six weeks.

Price, Chicago Park Lawn, per pound $60 \mathrm{c}$ Columbian-Fine for sheltered and shady places. $60 \mathrm{c}$ per pound.

Note-Ground in the shade that is sour and covered with moss so nothing else grows, should have an application of lime, one bushel to each 1,000 square feet. 


\section{Roses}

There is nothing in flowers that takes the place of Roses. There is nothing in flowers that can compare with them in beauty, grace and ornamentation. It is surely the Queen of Flowers. There is no other flower that is quite as appropriate for decoration.

In this latitude only the hardiest varieties of Roses can be grown with success unless they have some winter protection. By laying the bushes down and covering with coarse materials or wrapping with straw or burlap, the half-hardy varieties may be grown with good results, and one is amply repaid for the trouble. By planting the proper selection of kinds one may have a succession of bloom from June until freezing weather in October.

In planting Roses one should bear in mind that new and vigorous growth is what produces the bloom, and this can be attained only by cutting back the top to within three or tour inches of the ground as soon as planted. Another essentia! is good, deep, rich soil and clean cultivation; these are abolutely necessary for success.

Roses must have a sunny situation and are not to be planted in the shade of trees or buildings.

Our Stock contains a variety of colors and is the very best for this latitude. The plants are two-year-old field grown, are in good dormant condition, and will bloom the first season. They are not to be compared to greenhouse plants from small thumb-pots sold at a low price.

\section{Bedding or Dwarf Varieties}

BABY RAMBLER-In color resembles the Climbing Crimson Rambler very drarf and cmpact, attaining but 18 inches in height. Excellent for bordering beds of large roses or for beds by themselves. Bloom full during the entire season. Flowers in clusters of very small roses. Each $\mathbf{7 5 c}$.

ELLEN POULSON-A bright rosy-pink. Flowers very small, borne in large clusters throughout the season. Each $\mathbf{7 5 c}$.

CECIL BRUNER-A polyantha variety with dainty double little flowers of perfect form produced in many flowered graceful sprays. Color a soft rosy-pink on a rich creamy-white ground. Very showy. Each 75c.

GROOTENDORST-This might properly be called a Rugosa Baby Rambler, it being a cross between the Rugosa and Crimson Rambler. It is absolutely hardy and continues in full bloom from June until November. It is admirably adapted for a hedge, grows about 3 feet in height and is covered with bright red clusters of bloom all the time. The foliage is a rich green, free from disease. Fine for single specimen or in beds. Each 75c.

NOTE-The above four for $\$ 2.50$, prepaid mail.

\section{Hybrid Perpetuals or Everblooming}

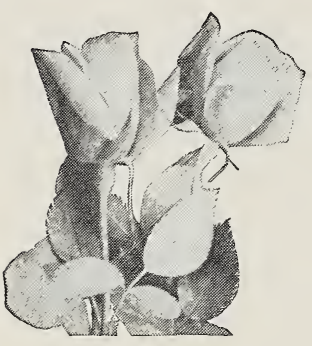

F. K. DRUSCHKI-A white American Beauty, long immense buds and perfectly double flowers. For bedding and cutting it is the finest of its class. Prolific and strong its class. Prolific and

NOTE-The four for $\$ 2.50$.

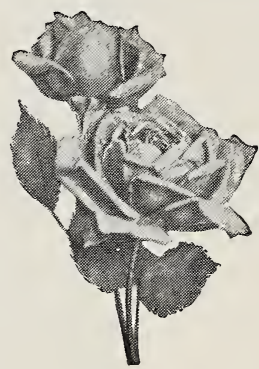

GEN. JACQUEMINOT-An old favorite. Brilliant scarle crimson, very fragrant. On of the oldest and best known Roses in cultivation. well everywhere. Each 75c.

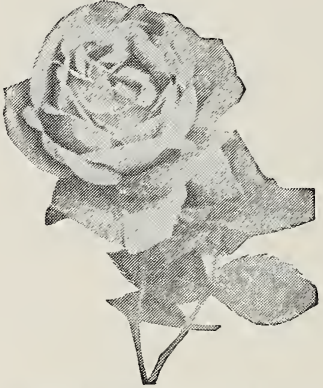

PAUL NEYRON-This magnificent Rose is by far the largest in cultivation, very double and full; deep rose color and delightfully fracrant. A very popular kind grant. A very popular kind Each 75c.

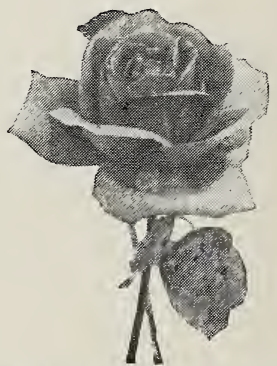

GRUSS AN TEPLITZ-Rich scarlet shading to a velvety crimson; very fragrant, a fre strong grower, in bloom all the time. This Rose should be in every garden as it sucthe most ordinary conditions. Each 75 c

\section{Climbing Varieties}

CRIMSON RAMBLER - Well known and very popular; strong rapid grower, covered in season with large and brilliant clusters of crimson flowers. Each 75c.

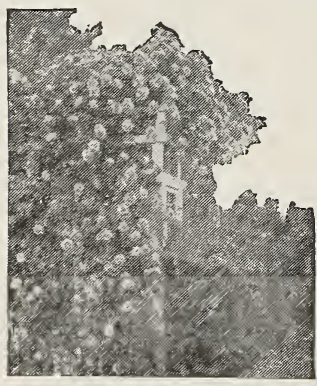

Crimson Rambler than most of the climbing roses. Each 75c.

PAUL'S SCARLET CLIMBER - No other climbing Rose can compare with this for brilliancy of color which is maintained until the petals fall. The flowers, a vivid scarlet, are of good size, semi-double, very freely produced in clusters of from 3 to 20 flowers each on much branched canes, the plants being iterally covered from top to bottom with bloom. It is of strong climbing habit and perfectly hardy. This is one of the most popular climbing Roses. Each 75c.

\section{Miscellaneous Roses}

PERSIAN YELLOW-An old favorite, blooms very early, before any other kind. Very double, rich yellow. Plants of a shruby growth and very hardy. Each $\mathbf{7 5 c}$.

ROSA RUGOSA-Japanese wrinkled rose, perfectly hardy and fine for massing with other shrubs. Blooms in large clusters in June and occasionally during the summer and fall. Extremely hardy. Each 50c.

LUXEMBOURG - Moss Rose of dark crimson color; one of the finest of this class. Blooms freely in June. Each 50c.

ROSA SETIGERA (Illinois Prairie Rose)-Blooms single, light pink in large clusters. Season two weeks after other varieties are past. Season July. Good foliage and of course hardy, being a native. Each 50c.

ROSA HUGONIS-This species from China is unlike any other Rose. It is of shrub-like habit of growth and naturally forms symetrical bushes about 6 feet high and in same diameter. It is valuable to plant among shrubs or for making a hedge. It has a clean healthy foliage of the Briar type; delicate yellow single flowers in June, and after it has finished blooming it remains an attractive, decorative bush for the balance of the season. Each 75c. 


\section{Evergreens}

\section{Our Front Cover Collection is a Wonderful Value}

Evergreens are invaluable for beautifying grounds. They are used for specimens on the lawn and also extensively for massing, shelter-belts, screens, hedges, etc. For winter cheer they are unexcelled. Their bright warm foliage is always a welcome note in the landscape, but with the branches arched and laden with snow, the deep green needles standing out in the contrast, they present a picture of indescribable beauty.

For planting around the house as a foundation planting, they give a color and warmth that cannot be obtained with any other trees. Only an inspection of our stock can give an adequate idea of the variety of color effects they present. There are deepest and lightest greens, bright and sombre golden tints, and soft st eel-greys and blues.

\section{Varieties}

\section{Arbor Vitae}

AMFRICAN ARBOR VITAE-One of the most valuable of the native Evergreens and one of the most rapid growers and probably the easiest of all to transplant; in fact, they will grow almost as readily from a cutting as a willow. They make a tree 60 feet and up and make very rapid growth the first few years, or up to 20 feet in height. It is a native of this state and all over the northern part of the U. S. and Canada. From this tree comes the White Cedar post, telegraph poles, railroad ties, etc. It thrives in most any situation; no place too wet or too dry. Fine for windbreaks and for ornamental hedging as it shears well and for windbreaks and for ornamental hedg
makes a very dense evergreen hedge.

makes a very dense evergreen hedge.

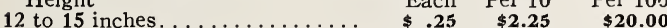

18 to 24 inches. . . . . . . $\ldots \ldots \ldots \ldots, \quad \mathbf{. 5 0} \quad \mathbf{4 . 5 0} \quad \mathbf{4 0 . 0 0}$

2 to 3 feet..............

2
3 to 4 feet...............

4 to 5 feet........ $2.00 \ldots \ldots \ldots \ldots \ldots \ldots \ldots \ldots$

ARBOR VITAE GLOBOSA-Very dwarf, dense, round shape. Suitable for bedding and foundation planting. Spread.

A good many fail with evergreens on account of improper treatment. In transplanting, the roots should never be allowed to become dry, as no amount of soaking will restore them.

The large-sized specimen trees we furnish with a ball of dirt, which insures the success of transplanting. The large trees produce an immediate effect. Trees dug with ball of earth about the roots and tightly sewed in burlap (B. \& B.) may be shipped to any part of the country and planted with success.

Note-Where trees are dug with solid ball of earth they can be successfully planted at any time during the season, even during the hottest weather.

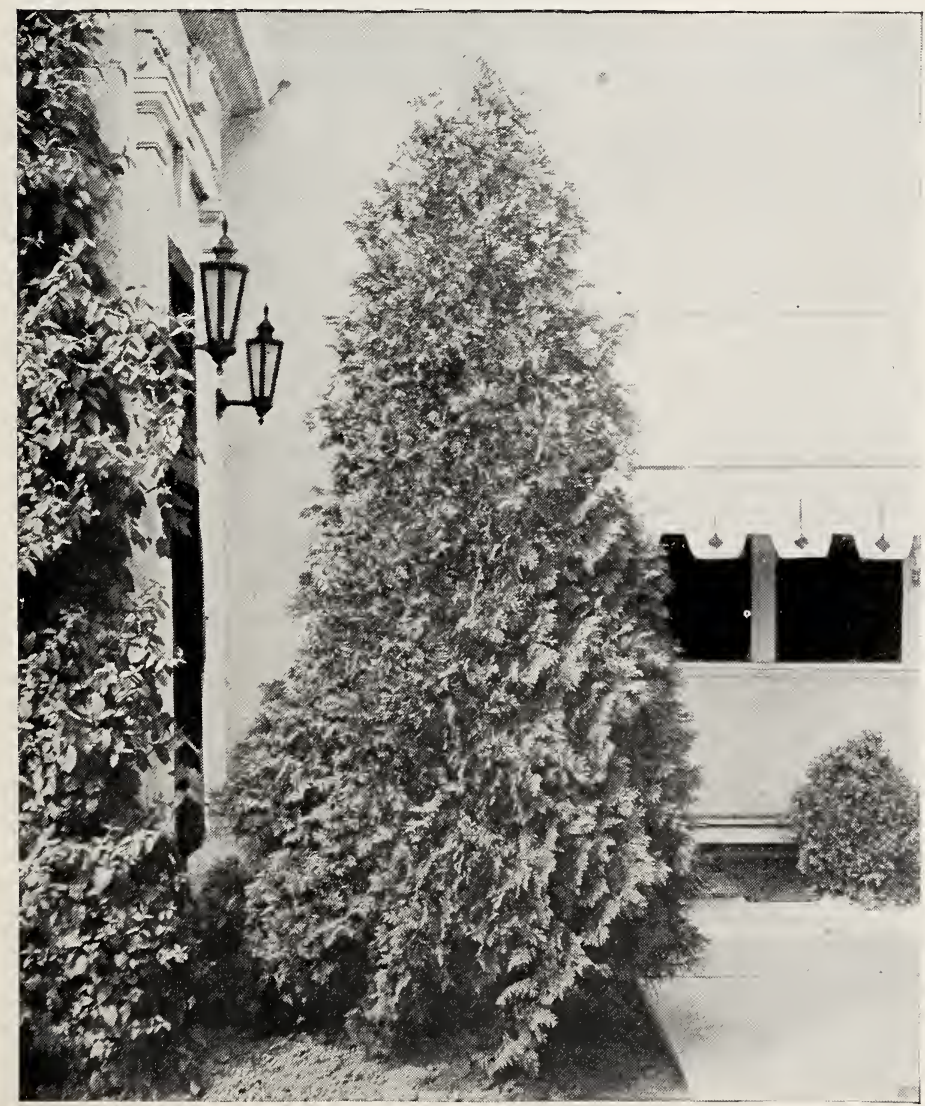

A judicious planting about the home indicates refinement as well as increased selling value

RBOR VITAE PYRAMIDALIS - A dwarf variety of very dense, compact growth and very narrow upright habit and of a deep 2 feet in diameter. Absolutely hardy anywhere and splendid for formal plantings.

$$
\text { Height. }
$$

Each 18 to 24 inches.

ARBOR VITAE SIBERIAN-A very symmetrical dwarf grower of lasting dark-green color and dense, neat habit. Matures at 6 to 8 feet. Very fine for foundation planting or in groups with other kinds.

ARBOR VITAE PEABODY'S - A golden-yellow variety of dwarf habit. Fine for planting in contrast colors with other kinds and also for foundation planting.

Height.

15 to 18 inches 


\section{Evergreens, Continued}

\section{Juniperus}

JUNIPERUS HIBERNICA (Irish Juniper)-Dwarf-growing Juniper of very upright, dense, columnar habit, with bluish-green foliage. One of the finest for formal plantings; makes a narrow column. Indispensable for gardens, beds and formal grounds.

$$
\text { Height. }
$$

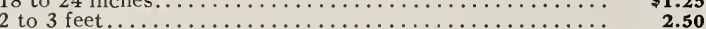
3 to 4 feet.

JUNIPERUS HORIZONTALIS (Waukegan Juniper)-A trailer of low, dense habit, covering the ground while not growing over 6 to 8 inches in height, it will spread to 8 or 10 feet in diameter under favorable conditions. The color of the foliage is a soft blue in the spring and summer, but changes to a rich purple in the late fall. As a ground cover for rock gardens, for Japanese gardens, or edging to evergreen borders, it has no equal.

8 to 24 inc.

Each
$\$ 1.50$

JUNIPERUS SABINA (Savin Juniper)-A low, much branched, spreading shrub 2 to 3 feet in height; its branches well supplied with short, straight, tufted branchlets, which are well clothed with dark green foliage. Its dark foliage gives it a very striking appearance planted with other evergreens. Does well in smoky atmosphere. Spread.

18 to 24 inches.

Each

JUNIPERUS PFITZERIANA-Dwarf, low, irregular, spreading,vaseshaped, of bush-like form, with dense gray-green foliage of soft, feathery appearance. Extremely hardy and seems to do equally well in cool shady places as hot sunny situations; in fact it does well any situation. Very valuable for foundation and group planting. 18 to 24 inc.

Each

\section{Fir}

FIR BALSAM - A very regular, symmetrical tree of upright, conical form; foliage dark-green above and silvery beneath. All parts of the tree have a very agreeable fragrance. The "Balsam" used in medicine is obtained from this tree. Fine for lawn specimen or for grouping.

18 to 24 inches.

Each

\section{Pine}

PINE, AUSTRIAN-A very compact, symmetrical, sturdy tree. The leaves are 4 to 6 inches in length, are dark-green color. A very rapid gtower and makes a splendid specimen when planted alone and contrasts well planted with other Evergreens. Height.

Each 2 to 3 feet.

$\$ 1.50$

PINE DENSIFLORA (Japanese Red Pine)-Introduced from Japan; very rapid growing while young, becoming very picturesque when older. Leaves 3 to 5 inches long, of a very brightgreen color. Valuable on account of its quick growth and beautiful green color. Height.
Heigh 18 to 24 inches.

PINE MUGHO (Shrub Pine)-A dense, low, round, shrub-like Pine of dark-green foliage; extremely slow growth. Fine for planting in front of other groups of evergreens and where a formal planting is desired. Height.
8 to 24 inches

2 to 3 feet.

Each

PINUS PONDEROSA (Heavy or Bull Pine)-Very heavy growing, with massive needles 6 to 10 inches long of deep green color on the surface and bluish-white underneath. Habit of growth tall and well rounded, pyramidal shape. Contrasts well with other evergreens in group planting.

$$
\text { Height. }
$$

Each 4 to 5 feet.

$\$ 3.50$

PINE, SCOTCH-A valuable timber tree of Northern Europe, familiarly known in Scotland as "Scots Fir." It is one of the fastest growing of the Pines and makes a very beautiful tree while young, but is inclined more to the picturesque when aged. A very hardy, rugged tree.
18 to 24 inches.
Each
18 to 24 in
$\$ .75$

WHITE PINE-Hardy ornamental Pine, of very rapid growth, svmmetrical when young, picturesque in old age. Leaves soft bluish-green, long and slender, and easily moved by the slightest breeze, so that a constant sighing and moaning is kept up which has long been the theme of the poets. A native of the northern part of the United States and the tree that our the White Pine lumber comes from. Each season's growth is plainly noticeable as the branches are grown in whorls or tiers and the age of any tree is easily determined by counting these whorls. On account of its very fast growth and subsequent immense size, it makes a splendid tree for tall background planting, also

\begin{tabular}{|c|c|}
\hline 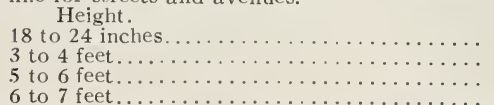 & $\begin{array}{r}\text { Each } \\
\$ .75 \\
1.25 \\
2.25 \\
4.00\end{array}$ \\
\hline
\end{tabular}
fine for streets and avenues.

\section{Spruce}

SPRUCE, NORWAY-Large, fast-growing tree of northern Europe, very symmetrical and of pyramidal habit; dark green foliage, of ten with drooping branches. Its extreme hardiness and adaptability to all situations make it a most valuable tree when planted for shelter and screen as well as for single lawn specimen; where given room it branches from the ground up. Often planted as an evergreen hedge as it stands shearing well and makes a very striking hedge. Being so easily transplanted and of such rapid, dense growth, it has become the most popular evergreen for windbreaks.

Height.
18 to 24 inches.

18 to 24 inches.

4 to 5 feet...

$\begin{array}{rr}\text { Each } & \text { Per } 10 \\ \$ .50 & \$ 4.00\end{array}$

SPRUCE, COLORADO BLUE-A very hardy and handsome tree from Colorado, of sturdy, upright growth; color of foliage bluish-green to silvery white, rarely dark-green. The extra blue or silvery white specimens are called "shiners" by the trade and bring a higher price. The trees have heavy, horizontal, stout branches in remote whorles which become drooping as they get older. A very striking tree in appearance and the most admired of the Spruces and one of the finest for planting as single specimen in park or lawn.

$$
\text { Height }
$$
18 to 24 inches...................

SPRUCE HEMLOCK - This handsome evergreen is in a class by itself. It seems to grow equally well in the shade as in the open. There is probably no more beautiful evergreen than the Hemlock. It does not have the stiff, formal a ppearance of many of the evergreens, but is graceful and stately at the same time. With its dark-green, dense foliage, pyramidal-shape and light drooping branchlets, it is admired in every situation. Fine for ornamental hedging, as it shears well.

$$
\text { Height. }
$$

18 to 24 inches.

2 to 3 feet.

Each

SPRUCE, WHITE-A small-sized, pryamidal-shaped tree of slow and compact growth. The foliage is a light green with a bluish tint. This variety is seen on the market as Christmas Trees brought from the north, in preference to any other kind. Its slow, dense growth makes it valuable for foundation as well as for grouping with other stronger growing kinds.

$$
\text { Height. }
$$

18 to 24 inches.

Each 2 to 3 feet.... 


\section{Evergreens, Continued}

\section{Retinospora}

RETINOSPORA PISIFERA (Sawara Cypress)-A beautiful hardy evergreen from Japan, with soft, feathery foliage, with drooping branches. There are none of the Cypress that are native to America that are hardy in this latitude, and it is only in recent years that the Japan Cypress was found to be hardy here. They are similar to the Arbor Vitae, but finer texture of foliage and more spreading habit.

Height.

Each 10 to 15 inches....................\$\$1.00

RETINOSPORA PISIFERA AUREA (Golden Sawara Cypress)-Same as the above, but with golden-tipped foliage. Fine for foundation and group planting, as it contrasts well with other evergreens.

Height.

2 to 3 feet.
3 to 4 feet.

Each

RETINOSPORA PLUMOSA (Plume Cypress)-A dwarfgrowing variety with dark, dense plume-like foliage with a spreading, conical habit. A beautiful variety for lawn planting, of slow growth with branches light and graceful at the ends. Relatively rare, but very desirable.

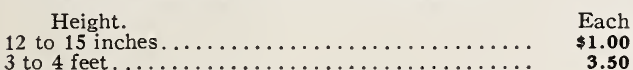

RETINOSPORA PLUMOSA AUREA (Golden Plume Cypress) - Same as the above, but tips of the branches a golden-yellow during the growing season and with a golden tint during the winter. Contrast well with other evergreens in foundation planting or grouping.

Height. 12 to 15 inches......................

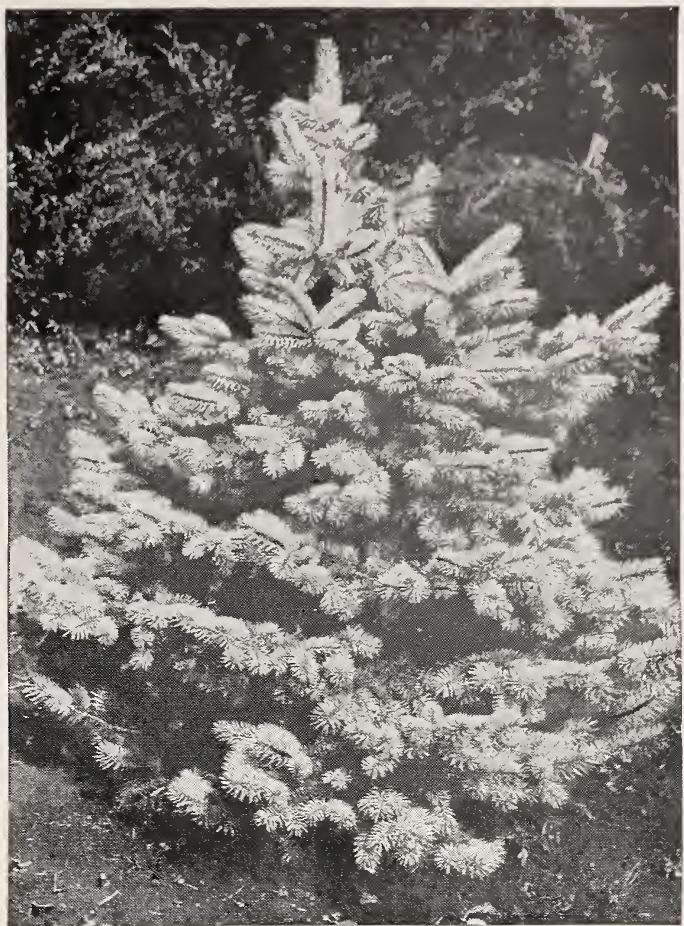

Colorado Blue Spruce

Evergreens carry their beauty and charm the year round and perhaps are even most appreciated in the winter, their warm, green foliage contrasts so sharply with the barren winter landscape and their graceful branches bend under a mantle of newly fallen snow.

Buy of Us and cut out the Middleman's profit-it's a big saving.

New home of Harry Williams, Esq., one of the proprietors of the Famous Store, Galva, Illinois, showing a twoyear planting of Evergreens, which blends itself beautifully with this type of bungalc $\mathrm{N}$. Planting designed and executed by the Home Nursery Landscape Service.

ts

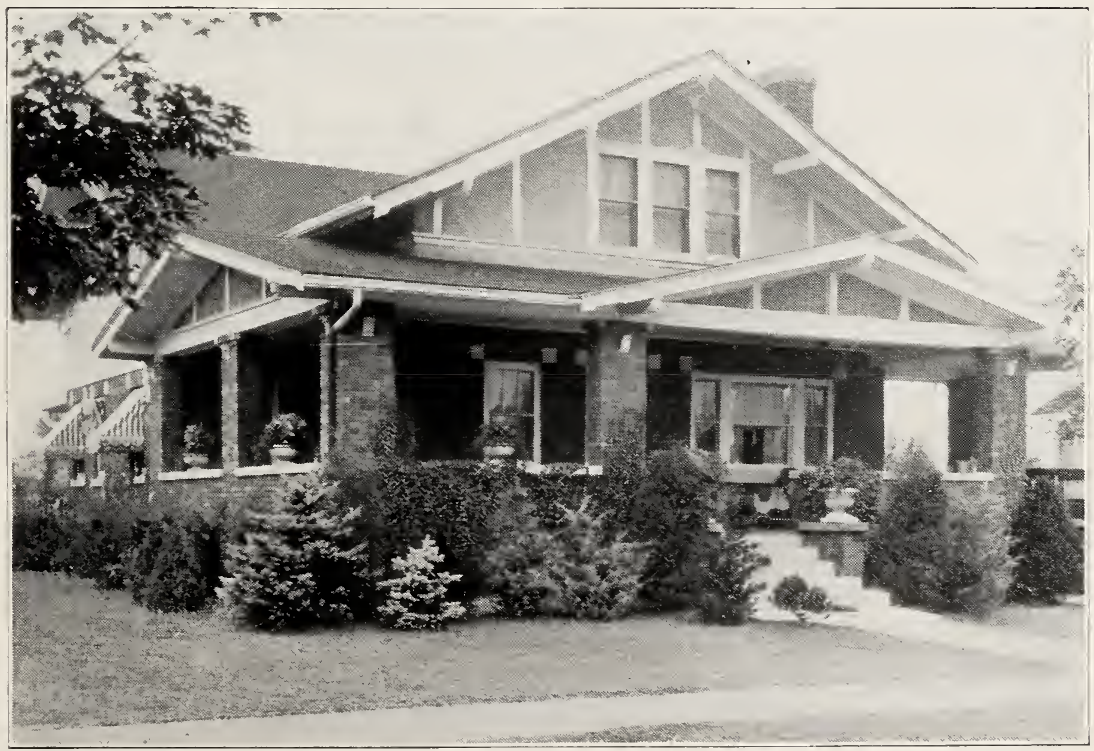




\section{Suggestions to Planters}

When to Order. To avoid disappointment in getting varieties wanted one should place the order early to be shipped at planting time. Besides we can give our customers much better service if we time. Besides we can

In this latitude, we consider spring planting preferable, although a good many hardy trees and plants can be transplanted in the fall with success, but stock that is inclined to be tender is injured to some extent by being planted in the fall this far north. Where planting is done in the fall it should be deferred as late as possible to give the stock time to fully ripen. When fully matured it will stand the winter usually without injury.

Care of Stock on Arrival. If stock appears dry when received from being long on the road, place them with their roots in water or bury roots and top in moist dirt for a few days until revived before planting. It is very important that the package should be opened up immediately to ascertain its condition, instead of allowing it to lie around several days until you are ready to plant.

Mulching. Good cultivation is the best mulch during the early part of the summer, but as the weather becomes hot and dry a mulching of coarse litter will hold moisture and be of benefit.

Planting. Do not expose roots to sun and wind for any length of time. It is highly injurious and fatal to Evergreens. Cut back all roots to good live tissue. A freshly cut root will start into growth very much sooner than one with an old or broken wound.

Fill in around the roots with good mellow dirt, without trash of any kind. Roots in order to draw moisture from the soil must have the soil packed firmly around them. A good plan is to flood the hole with water during the process of filling.

The hole should be dug twice the size necessary to receive the roots.

Labels. Remove all labels as soon as planted, as they will surely injure the tree as soon as the bark begins to swell.

Cultivation. Hoe or cultivate frequently during the growing season. Nothing can thrive if the weeds or grass are allowed to sap the life out of the soil.

DISTANCES FOR PLANTING

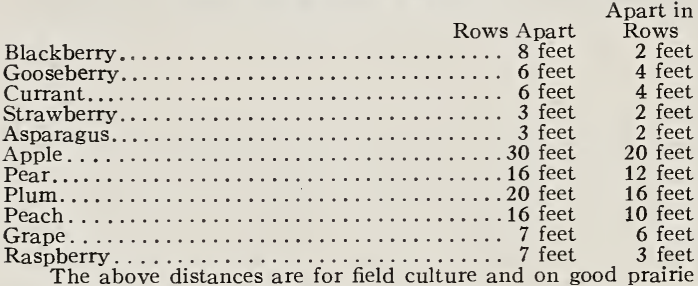

land. On light soil, plant closer.
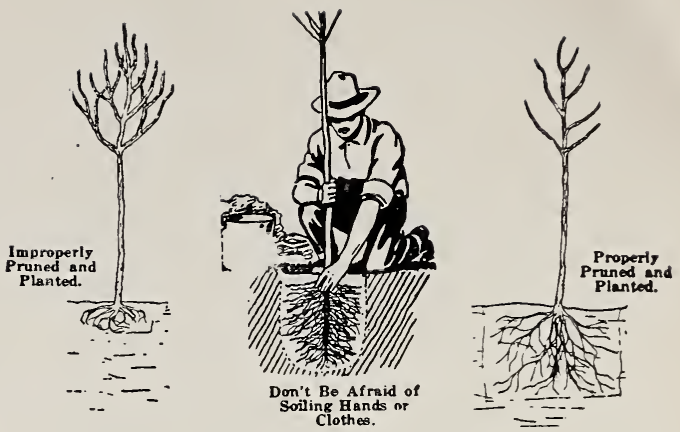

Information on Spraying

Information that the average farmer and fruit growerareignorant of:

There are two distinct kinds of insects-those that eat foliage (chewing insects) and those that suck the juices of trees and plants (sucking insects). The former are controlled by putting poison on the foliage and the other by a direct application of poison to the insect.

There are a number of arsenical poisons that can be used by diluting with water or Hydrated Lime. We find that Arsenate of Lead is as good as any, using one pound of the lead with four pounds of lime to fifty gallons of water, for chewing insects.

For sucking insects, any of the miscible oils (oil emulsion) may be used; also, Nicotine Sulphate, either of which when diluted must be sprayed directly upon the insects.

Any of the spraying chemicals can be obtained of your druggist, and directions will be found on the containers.

The Codling Moth is the worst enemy the apple grower has to contend with and, uncontrolled, will usually put a worm in each apple.

The first brood of eggs are laid in the calyx or blossom end of the young apple when very small. Now if the poison can be sprayed into the calyx early it will be protected from the little worm that hatches from the moth's egg laid there.

To get the poison into the calyx ahead of the worm is the problem. As the calyx in most varieties closes down soon after the young apple begins to swell or grow, which is soon after the blossom falls, the spraying must be done immediately while the calyx is wide open. The rule is to spray when the blossoms are half off. This is called the Calyx Spray and is the most important of all.

Fungus diseases, such as canker, brown-rot, scab, leaf-blotch blight, etc., are controlled by spraying with lime-sulphur or Bordeaux, either of which may be applied at the same time as the peisons.

Write State University of Iliinois at Urbana for Spray Bulletin

If we do not send you just what you order, and of the best quality, we cannot expect to hold your trade or have you recommend us to your friends.

\section{Grave Covers}

A good many of our Customers are asking for Evergreen Boughs to cover the graves during the winter, of their departed friends. This is a very commendable service and a fine way to remember loved ones gone on before. To accommodate this trade we are growing Spruce and Pine boughs specially suited for this work. When placed on the graves late in the fall they will hold their foliage and dark green color throughout the winter. Price for enough toughs to cover one grave \$1.50.

\section{Broad-leaved Evergreens for Graves}

We also have Broad-leaved Evergreen Plants suitable for planting on graves for a permanent cover. They are very hardy and make a green carpet-like effect over the grave. These will grow and last indefinitely without any care and will thrive either in shade or open places.

\section{Varieties}

VINCA MINOR.-(Periwinkle or Myrtle).

JAPANESE SPURGE.-(Pachysandra Terminalis)

For description of the above, see on page 23 under Vines and Creepers.

Each, $25 \mathrm{c} ;$ per $10, \$ 2.00$ Each, 35c; per 10,\$3.00

\section{Christmas Decorations}

Ow ing to our large stock of Evergreens of various kinds we are able to furnish Boughs, either large or small, of Pine, Spruce, Arbor

Vitae or Cypress, suitable for inside of stores or residences, and also for street or outside decorations.

We also have Wreathing Machines and are able to furnish Arbor Vitae wreathing for wreaths and festoons in any size or length.

Price Arbor wreathing, per yard, 15c. In lots of 500 yards and over, $121 / 2 \mathrm{c}$.

\section{Christmas Trees}

We have a few large specimen Spruce Christmas Trees that have been planted over 30 years, that run from 20 to 30 feet in height, suitable for Church and Community trees. Also a quantity of small trees suitable for store and house decorations. Prices on application.

\section{Index}

\section{Fruit Department}

Greenhouse Department

Ornamental Trees.

Ornamental Shrubs.

Note.-Specia
Pages 4-11

Pages 12,13

Pages 14,15

Pages 16-22

Vines and Creepers. . .

Perennials.

Roses........

Page.
Page 23

Pages 24, 25

Page 26

Pages 27-29 
HOW TO ORDER-Fill out this sheet with the items you want. Be sure to give the size and Catalog Price, enclosing Postal Money Order, Bank Draft, or Personal Check for full amount of order. If ordered by mail or parcel post, the amount of postage should be added. On request we give the exact postage required to any Postoffice in the United States on any particular order.

Ladies, please prefix Miss or Mrs. to your names.

Orders less than $\$ 1.00$, add 25 c for packing.

\begin{tabular}{|c|c|}
\hline $\begin{array}{c}\text { Amount Enclosed With } \\
\text { This Order }\end{array}$ \\
\hline$s$ & Cts. \\
\hline
\end{tabular}

\section{HOME NURSERY}

IRVIN INGELS, Proprietor

\section{La Fayette $\therefore$ I11inois}

Date.

Name.

Postoffice.

State

Street and No.

R. F. D. No.

Express Office or Freight Station.

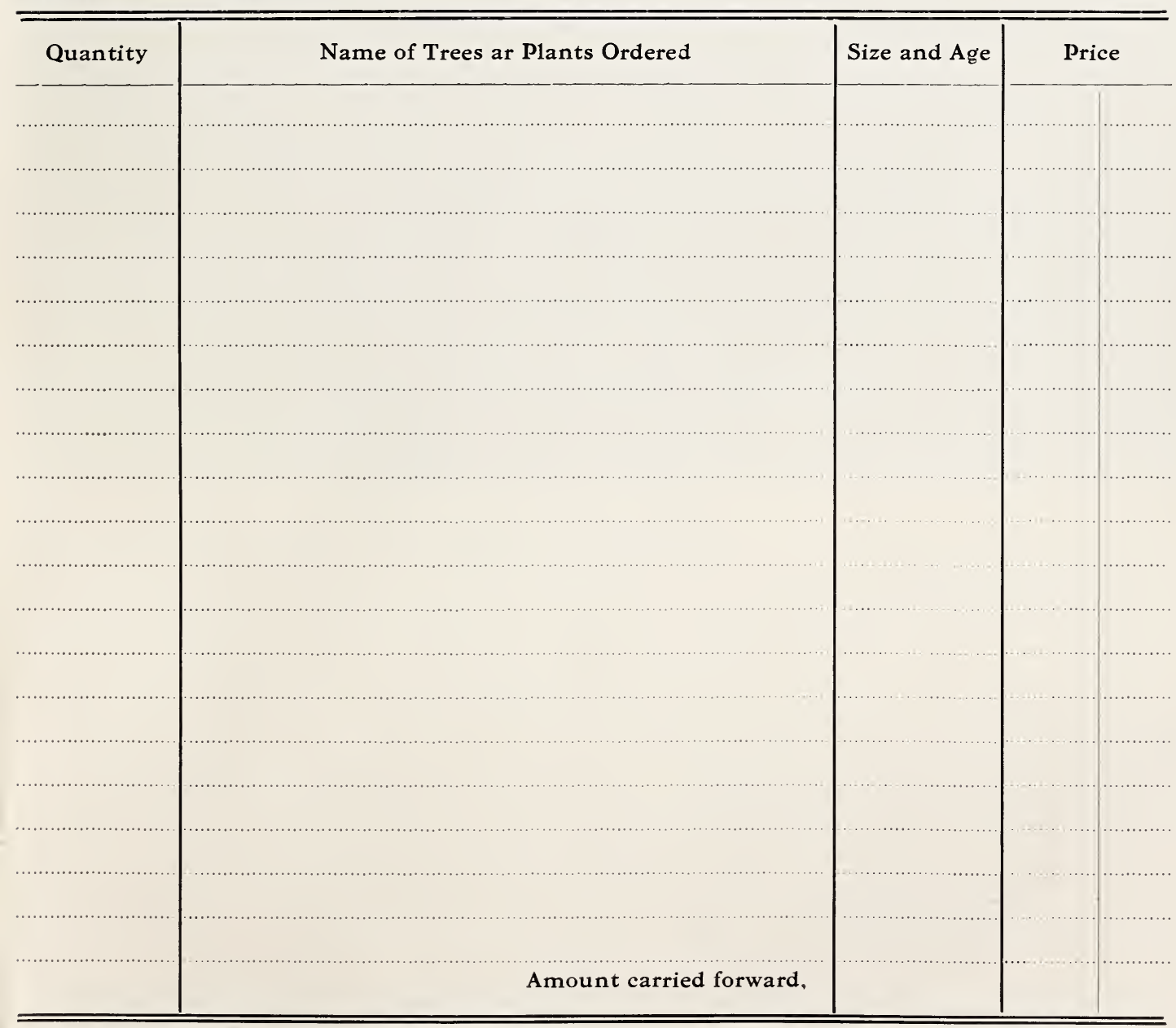

MY GUARANTY: While I exercise the greatest care to have my stock genuine and reliable, I agree to replace, on proper proof, all that may prove untrue to name as labeled, and it is hereby mutually agreed that my replacing it or offer to replace it shall operate as a liquidation of all damages. 


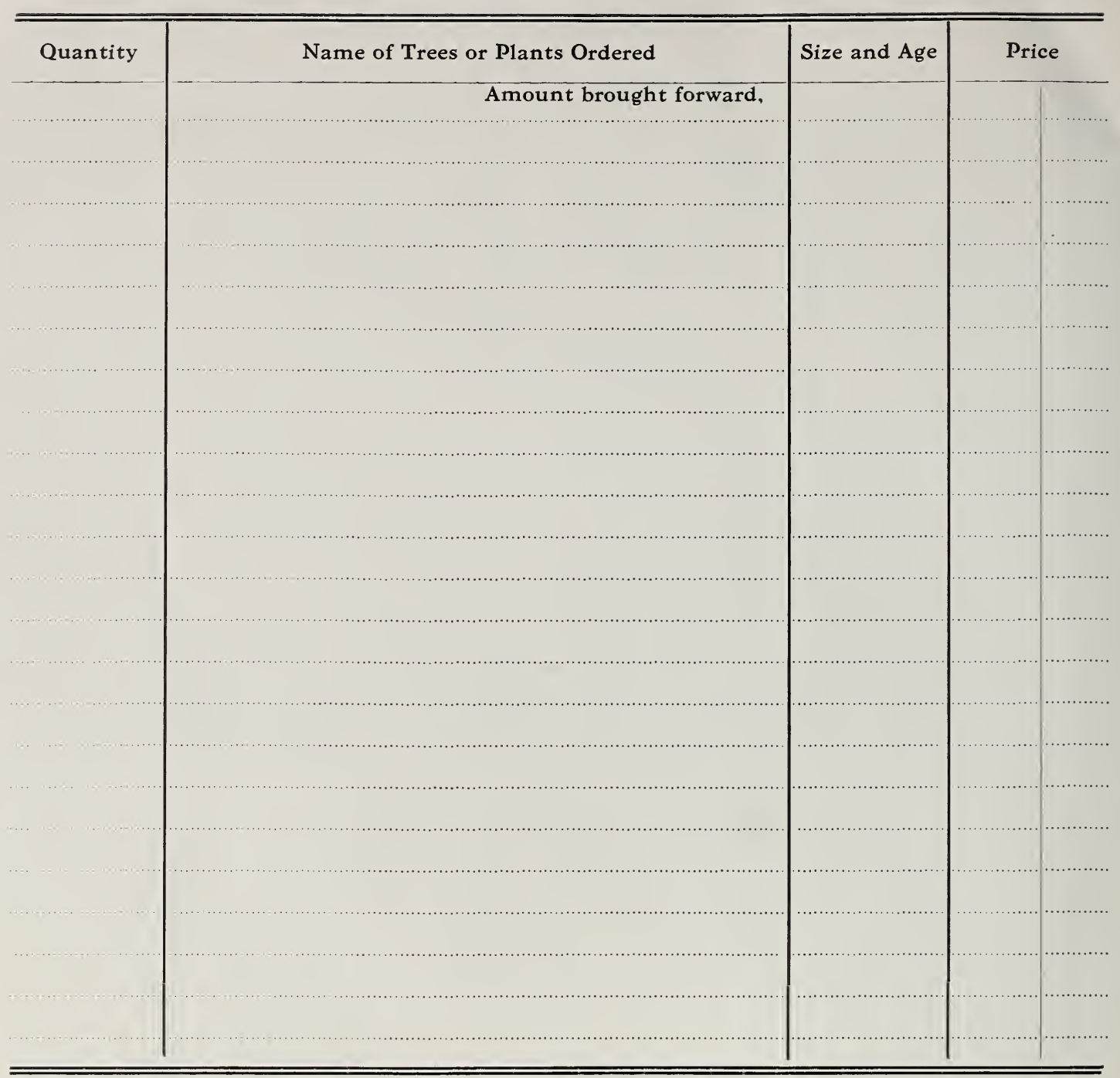

Please write below the names and addresses of your friends who are interested in and buyers of TREES, PLANTS, Etc.

Note.-Five will be furnished at the 10 rate; fifty at the 100 rate; and five hundred at the 1,000 rate.

SPECIAL NOTICE-All claims for error or shortage must be made immediately upon receipt of goods, as we do not guarantee beyond delivery. 


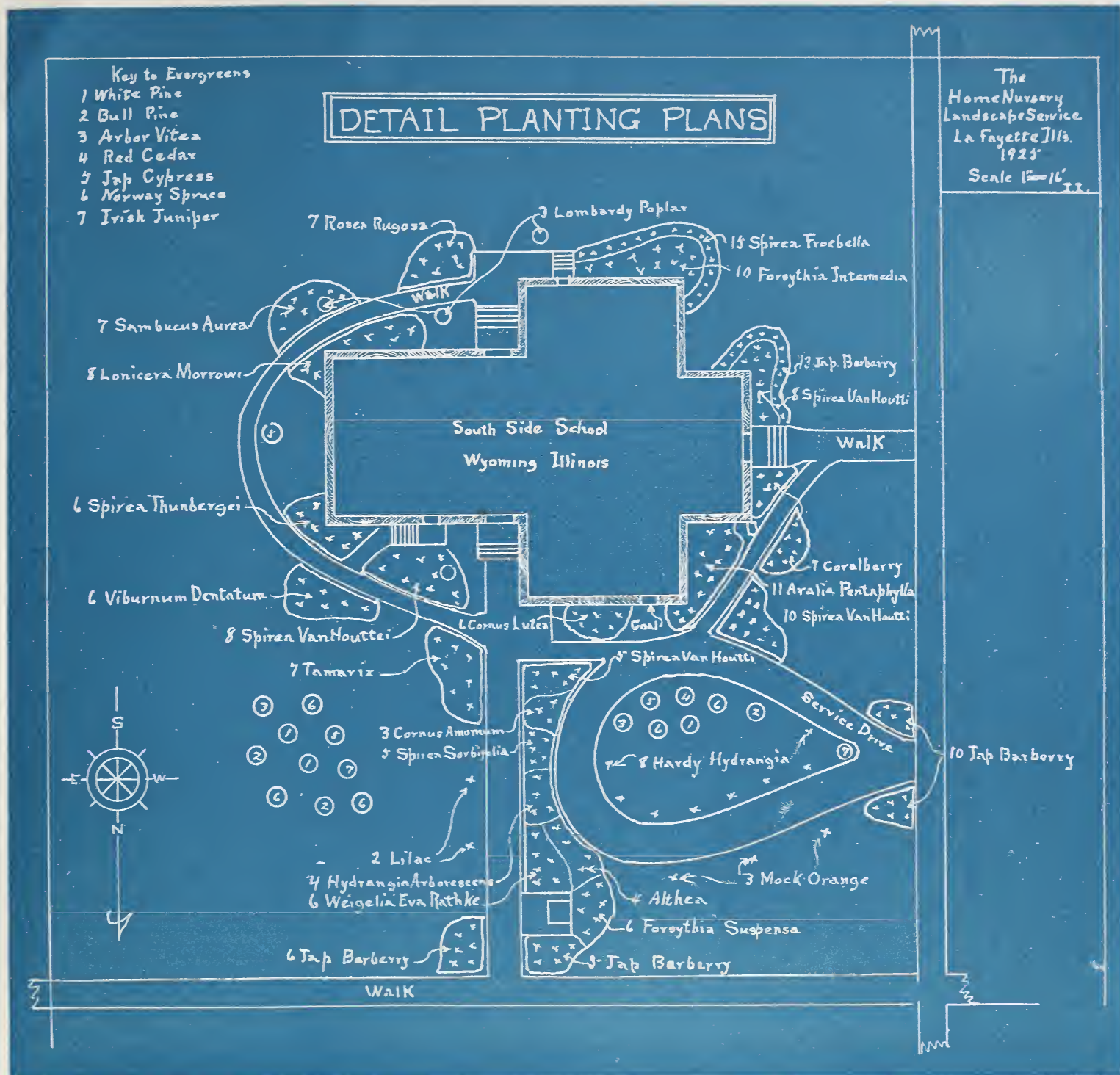

\section{Landscape Department}

The above cut is a fac-simile of the Blue Print furnished to the Wroming School Bcard of Wroming, Illinois, for beautifying their South Side School Grounds a few rears ago. The HOME NLRSERY LANDSCAPE SERVICE worked out a design, made the blue print, furnished the trees, shrubs and plants and did the planting. In fact, did everything from start to finish. And now that community is loud in its praise of their improved school grounds.

There is nothing that refects the civic pride of a community as do well kept public grounds, v hether large or small. The effect of attractive grounds surro!nding such instituticns is most inspiring, nct cnly creating local pride and community spirit, but giving a favorable impressicn of the community to all strangers passing through.

The landscape development of the grounds has become a prominent facter in home building. The word home means vastly more than a place to live. There is a deep, subtle meaning which implies cheerful surroundings, cordial relations, industrial habits, and a place where love and friendship abound. Our surroundings greatly influence our relations, habits and even temperament. So let us make our homes as attractive in surroundings as possible by planting trees, shrubs and plants.

Call or write us regarding any contemplated landscape improvements. II e consider it a pleasure to offer suggestions, without charge, to intending customers. Any particular grounds to be beautified is a problem by itself and requires a careful study and deliberate thinking. Our association with plants for so many years has taught us many things in connection with plant life which is fundamentally necessary for working out planting effects that are attractive and really have merit.

The many and varied landscape jobs we have executed during the past and our many years of experience, assure you of our ability to serve your needs in an entirely satisfactory manner.

Address:

HOME NURSERY LANDSCAPE SER VICE

La Fayette, Ills. 


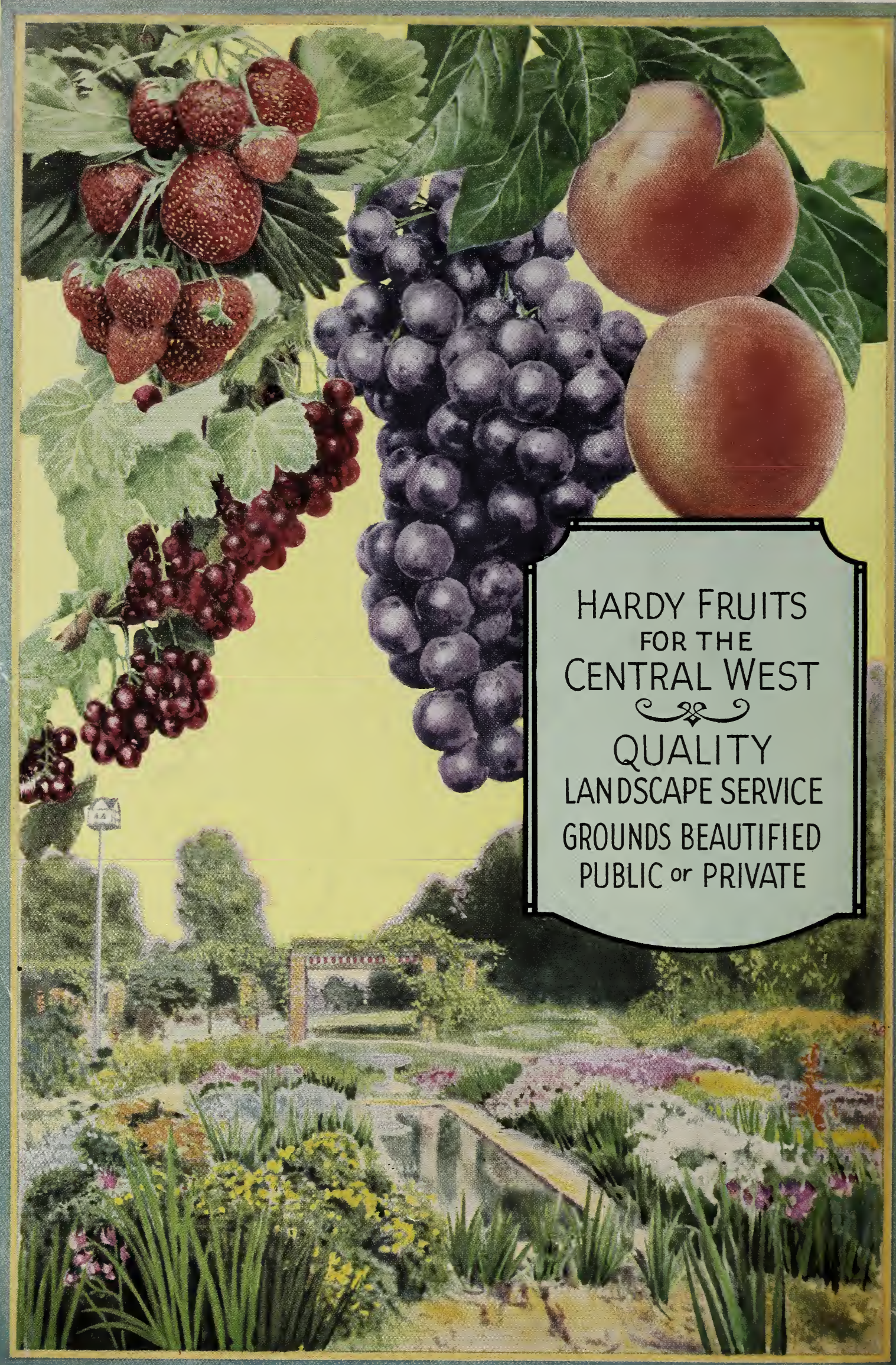

